\title{
(ख) ipen-
}

AUTARQUIA ASSOCIADA À UNIVERSIDADE DE SÃO PAULO

ESTUDO DO EFEITO DA RADIAÇÃO IONIZANTE EM COMPOSTOS ORGÂNICOS DO DIESEL E DO PETRÓLEO: HIDROCARBONETOS, SULFURADOS E NITROGENADOS

Luana dos Santos Andrade

Dissertação apresentada como parte dos requisitos para obtenção do Grau de Mestre em Ciências na Área de Tecnologia Nuclear - Aplicações

Orientadora:

Profa. Dra. Celina Lopes Duarte 
INSTITUTO DE PESQUISAS ENERGÉTICAS E NUCLEARES

Autarquia associada à Universidade de São Paulo

ESTUDO DO EFEITO DA RADIAÇÃO IONIZANTE EM COMPOSTOS ORGÂNICOS DO DIESEL E DO PETRÓLEO: HIDROCARBONETOS, SULFURADOS E NITROGENADOS

Luana dos Santos Andrade

Dissertação apresentada como parte dos requisitos para obtenção do Grau de Mestre em Ciências na Área de Tecnologia Nuclear - Aplicações

Orientadora:

Profa. Dra. Celina Lopes Duarte

Versão Corrigida

Versão Original disponível no IPEN

São Paulo

2014 


\section{AGRADECIMENTOS}

À Deus, pela oportunidade magnífica e por estar presente em todos os momentos, emanando sabedoria, amor, vida, alegria, provisão e harmonia infinita para vencer mais esse desafio.

Minha profunda gratidão a minha orientadora Dra. Celina Lopes Duarte por sua confiança, orientação, conselhos, inspiração e paciência, que me motivou em cada momento deste projeto.

Aos meus avós Elizabeth e Joaquim, por cuidarem de mim, pelo apoio e incentivo incondicional e por me ensinarem a ser uma pessoa melhor a cada dia, pelos conselhos valiosos.

A minha mãe Clara, pelas conversas, conselhos, paciência, incentivo e suporte emocional durante esta jornada. Ao meu padrasto Aldemir e irmão Lucas, pelo incentivo.

Aos colegas pelas conversas, incentivo, colaboração, paciência e carinho e pelos vários momentos de descontração: Adriano, Amanda, Cauê, Dayane, Diego, Fabio, Fernando, Patrícia, Rejane, Renato, Vanessa, (IPEN) e André, Line e Helena.

Ao IPEN, especialmente ao Centro de Tecnologia das Radiações, representada pela Dra. Margarida $M$. Hamada, gerente do CTR, gerentes adjuntos Dra. Mônica B. Mathor e Dr. Wilson A. P. Calvo pelo constante apoio e pré-disposição em ajudar e buscar soluções.

A Dr. Ivone Mulako Sato do centro de Química e Meio Ambiente pela imensa colaboração e apoio durante este projeto. 
Aos engenheiros Elizabeth Somessari e Carlos Gaia da Silveira, pela atenção e carinho, e pelo auxílio no processamento por irradiação das amostras.

À Claudia e ao Marcos pela ajuda nos assuntos administrativos .

Aos demais profissionais e bolsistas do Centro de Tecnologia das Radiações, pelo convívio harmonioso e enriquecedor.

A Capes pelo auxílio financeiro.

A todos que contribuíram tanto para realização deste trabalho, quanto na minha formação. 
O destino costuma estar ao virar da esquina. Como se fosse um gatuno, uma rameira ou um vendedor de loteria: as suas três encarnações mais batidas. Mas o que não faz é visitas a domicílio. É preciso ir atrás dele. Carlos Ruiz Zafón. 


\title{
ESTUDO DO EFEITO DA RADIAÇÃO IONIZANTE EM COMPOSTOS ORGÂNICOS DO DIESEL E DO PETRÓLEO: HIDROCARBONETOS, SULFURADOS E NITROGENADOS.
}

\section{Luana dos Santos Andrade}

\begin{abstract}
RESUMO
O petróleo é uma das principais fontes de energia e também de poluição no mundo atual. Novas tecnologias na indústria petroquímica visam diminuir a energia gasta no processamento e a redução dos produtos poluidores. Compostos de enxofre e nitrogênio geram problemas ambientais, sendo os mais relevantes, a poluição da atmosfera que afeta a saúde da população diretamente. A tecnologia nuclear tem sido usada na proteção ambiental através da remoção de poluentes pela reação com radicais livres produzidos pela ação da radiação nas moléculas de água. O objetivo desse trabalho é a avaliação do efeito da radiação ionizante no petróleo e no diesel, principalmente, nos hidrocarbonetos, nos compostos orgânicos sulfurados e nos nitrogenados. Para tanto estudou-se a molécula modelo de enxofre, benzotiofeno, e amostras de diesel e de petróleo bruto. As amostras foram irradiadas na fonte de Co-60 do tipo Gammacell. A concentração total de enxofre nas amostras foi determinada por fluorescência de raios- $x$ e os compostos orgânicos foram determinados por cromatografia gasosa acoplada ao espectrômetro de massas,GC-MS. O estudo com a molécula modelo demonstrou que cerca de 95\% foi degradado com uma dose absorvida de 20 kGy. Os resultados obtidos na análise dos hidrocarbonetos demonstram que estes foram craqueados quando irradiados com a dose de $15 \mathrm{kGy}$, entretanto observouse a polimerização e a baixa eficiência no craqueamento em doses maiores. Observou-se eficiência na redução da maioria dos compostos de enxofre do petróleo e diesel. Considerando as doses estudadas as que apresentaram melhor eficiência foram as de 15 kGy e 30 kGy. Na amostra de diesel as maiores variações nos compostos orgânicos foi observada com doses absorvidas de 30 kGy e 50 kGy. No petróleo, após a destilação e separação cromatográfica de coluna aberta utilizando cloreto de paládio como fase estacionaria, observou-se a separação preferencial de compostos orgânicos sulfurados.
\end{abstract}




\title{
STUDY ON IONIZING RADIATION EFFECTS IN DIESEL AND CRUDE OIL: ORGANIC COMPOUNDS: HYDROCARBON, SULFUR AND NITROGEN
}

\section{Luana dos Santos Andrade}

\begin{abstract}
Petroleum is the most important energy and pollution source in the world, nowadays. New technologies in petrochemical industry aim to minimize energy spending at the process and to reduce pollution products. Sulfur and nitrogen compounds generate environmental problems; the most relevant is air pollution that affects the population health directly. The nuclear technology has been used in environmental protection through pollutants removal by free radicals produced at action of the radiation in water molecule. The objective of this study is to evaluate the radiation effects on oil and diesel, mainly in the hydrocarbons, organic sulfur, and nitrogen compounds. It was studied a molecule model of sulfur, named benzothiophene, diesel and crude oil samples. The samples were irradiated using a Co-60 source, Gammacell type. The total sulfur concentration in the samples was determined by X-ray fluorescence spectrometry, and organic compounds were analyzed by gas chromatography coupled to mass spectrometry (GC-MS). The study of molecular model showed that $95 \%$ was degraded at 20 kGy dose rate. Irradiation at $15 \mathrm{kGy}$ of absorbed dose showed some cracking in petrol hydrocarbons, however with higher doses it was observed polymerization and low efficiency of cracking. It was observed that the sulfur compounds from diesel and petroleum was efficiently reduced. The applied doses of $15 \mathrm{kGy}$ and 30 kGy were the most efficient on desulfurization of petroleum, and for diesel the highest variation was observed with $30 \mathrm{kGy}$ and $50 \mathrm{kGy}$ of absorbed dose. The distillation and chromatographic separation using an open column with palladium chloride as stationary phase showed a preferential separation of organic sulfur compounds in petroleum.
\end{abstract}




\section{SUMÁRIO}

1. INTRODUÇÃO



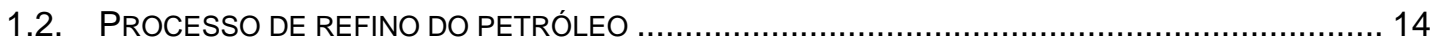

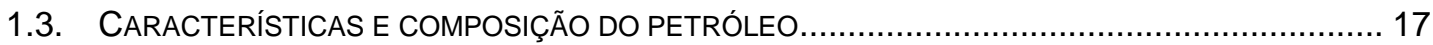

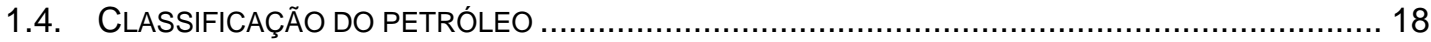

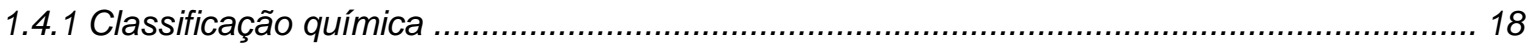

1.4.1.1. Classe parafínica (75\% ou mais de parafinas) .............................................................. 19

1.4.1.2. Classe parafínico - naftênicos (50-70\% parafinas, > 20\% de naftênicos) ........................ 19

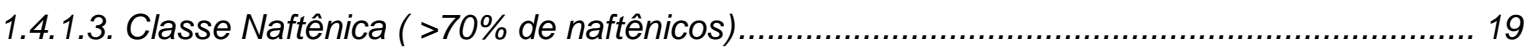

1.4.1.4. Classe aromática intermediária( $>50 \%$ de hidrocarbonetos a aromáticos) ........................ 19

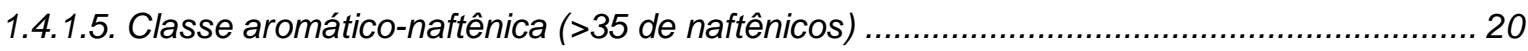

1.4.1.6. Classe aromáticos - asfáltica (>35\% de asfaltenos e resinas) ...................................... 20

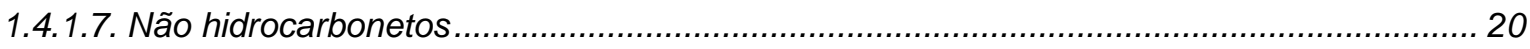

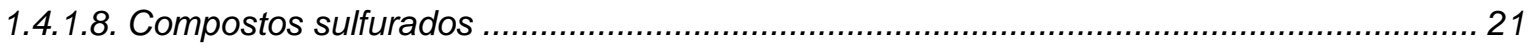

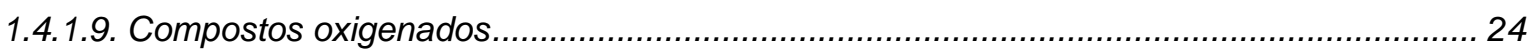

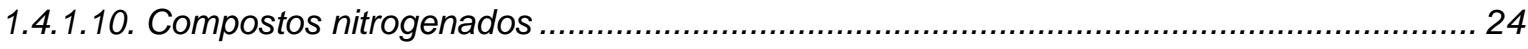

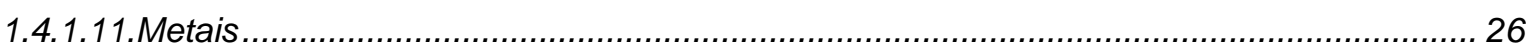

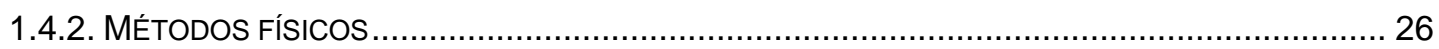

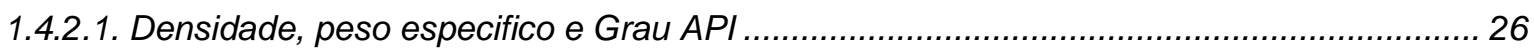

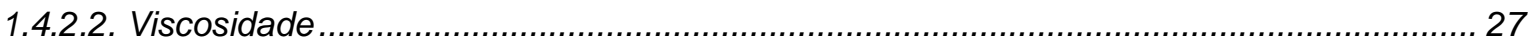

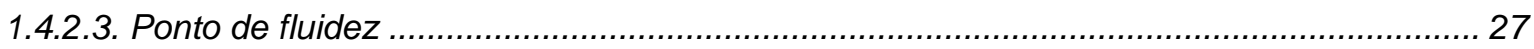

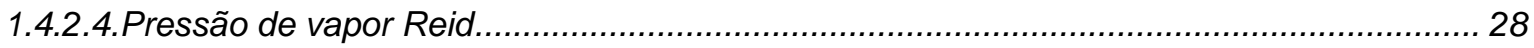

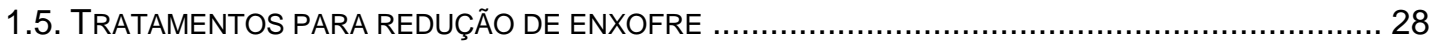

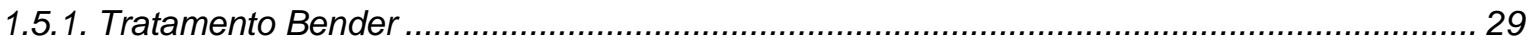

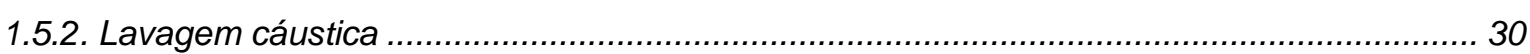

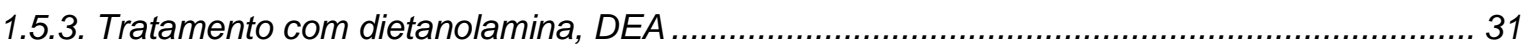

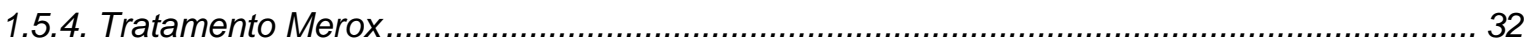

1.5.5. Hidrotratamento, Hidrodessulfurização e Hidrodesnitrogenação ...................................... 33

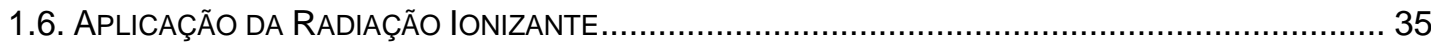

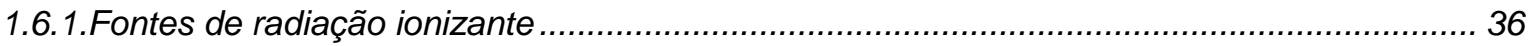

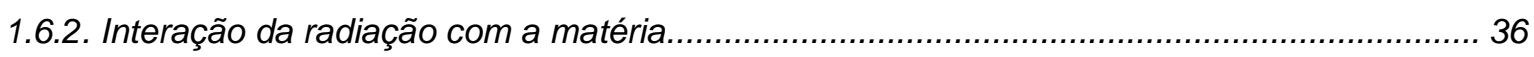

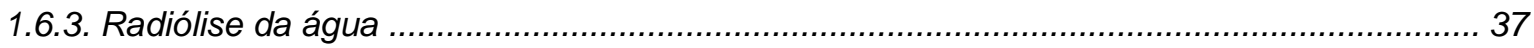

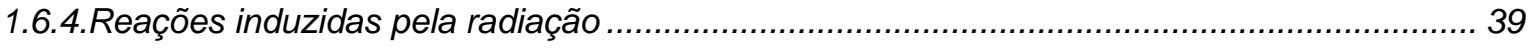

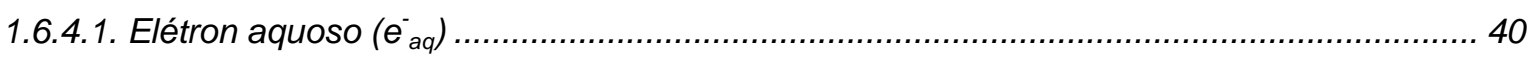

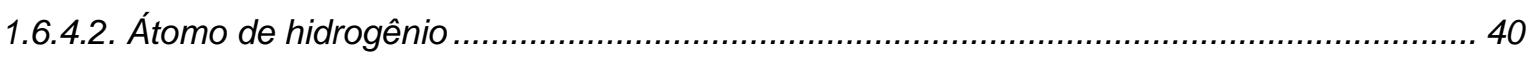

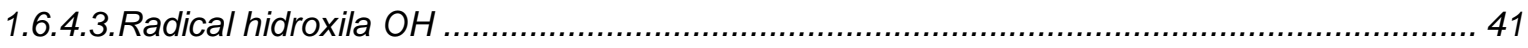

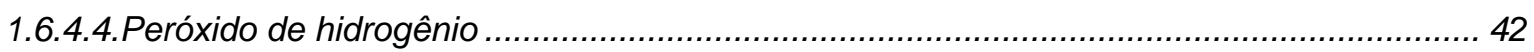

1.6.5. Interação da radiação com hidrocarbonetos saturados, insaturados e aromáticos. ............. 42

1.6.6. Craqueamento induzido por radiação em hidrocarbonetos ................................................ 45

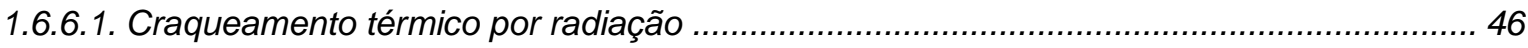


1.6.6.2. Aplicação da radiação ionizante na redução do teor de enxofre no petróleo.

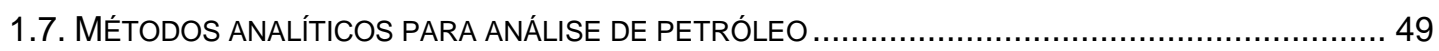

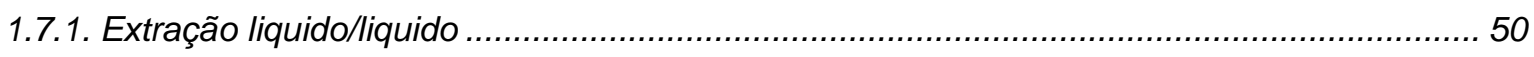

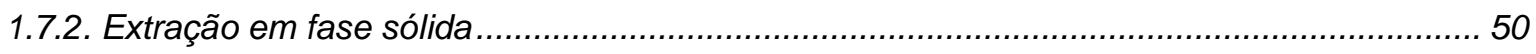

1.7.3. Cromatografia gasosa acoplada ao espectrômetro de massa ............................................. 52

1.7.4. Espectroscopia Infravermelho com Transformada de Fourier, FTIR................................... 53

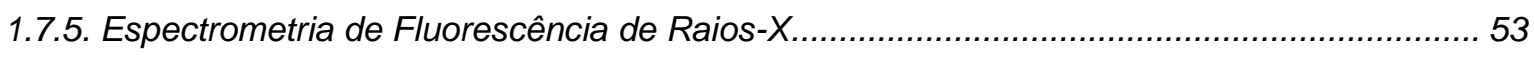

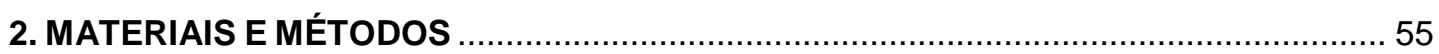

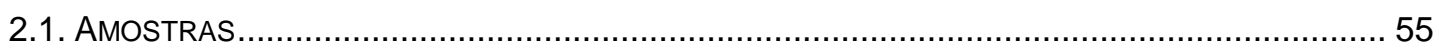

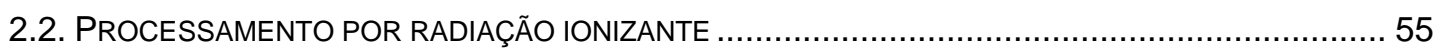

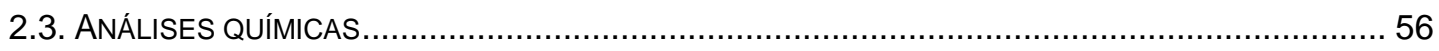

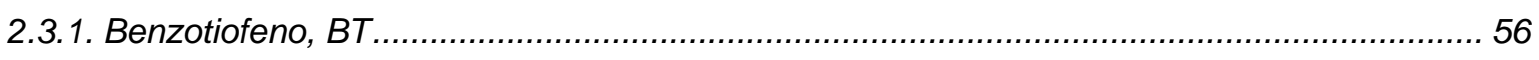

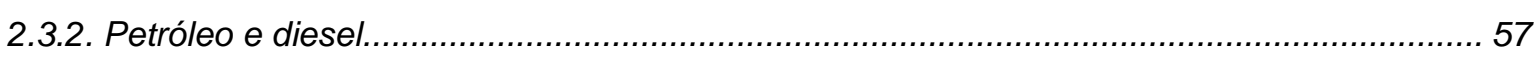

2.3.3. Separação química dos compostos sulfurados no diesel................................................... 58

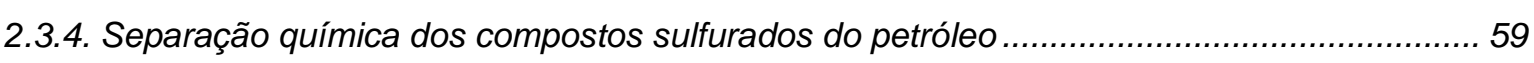

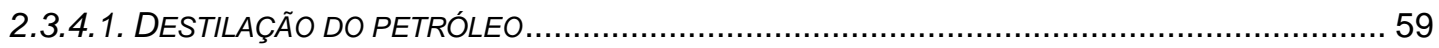

2.3.4.2. SEPARAÇÃO DOS COMPOSTOS SULFURADOS DO DESTILADO DE PETRÓLEO..................... 60

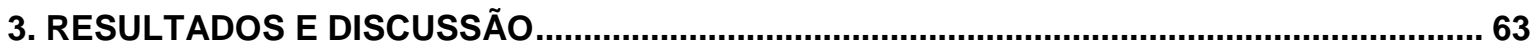

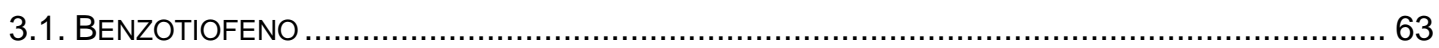

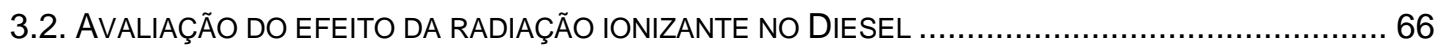

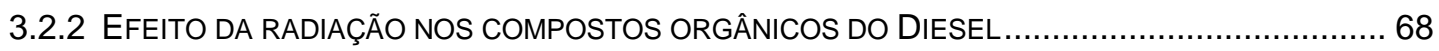

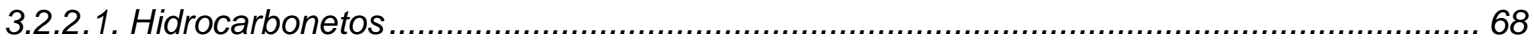

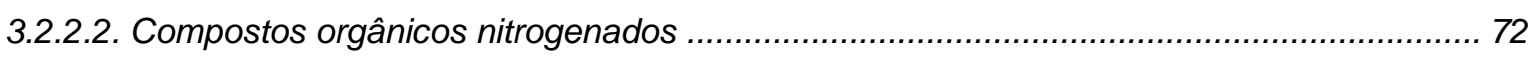

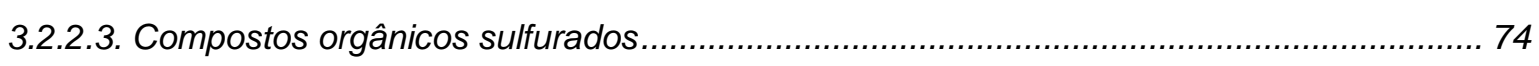

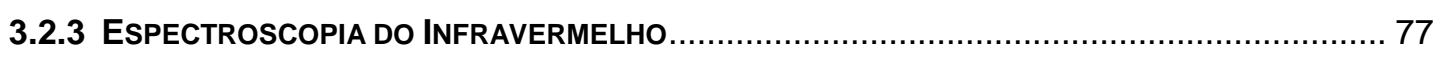

3.3. AVALIAÇÃO DO EFEITO DA RADIAÇÃO IONIZANTE NO PETRÓLEO ............................................. 78

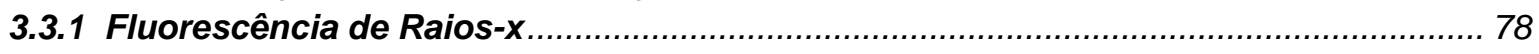

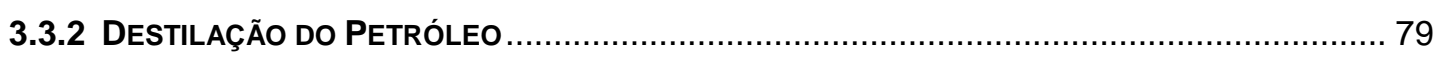

3.3.3 EFEITO dA RADIAÇÃo NOS COMPOSTOS ORGÂNICOS DO PETRÓLEO ……......................... 82

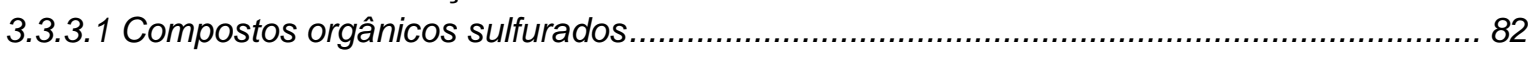

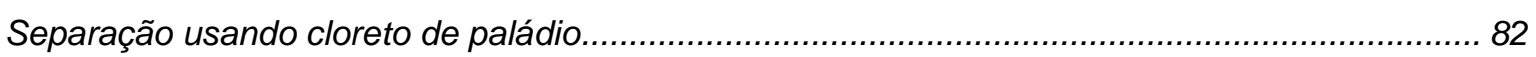

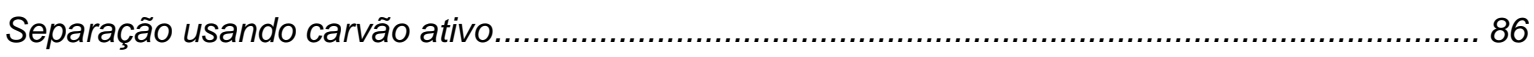

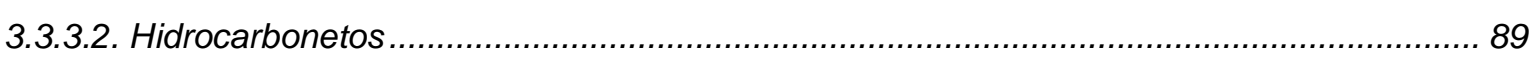

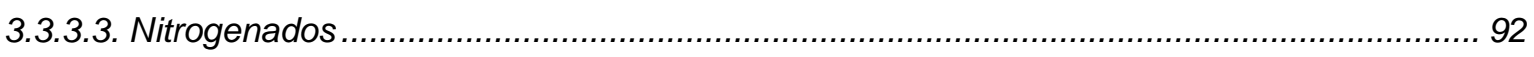

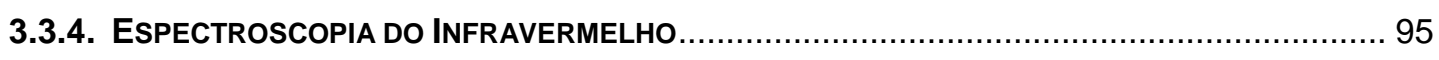

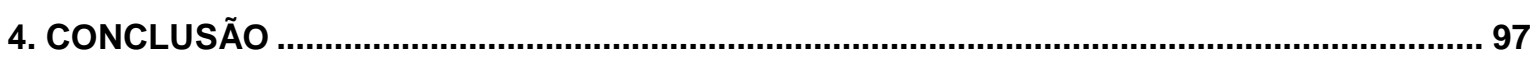

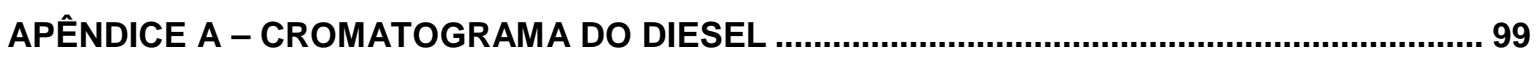

APÊNDICE B- CROMATOGRAMA DO PETRÓLEO: CLORETO DE PALÁDIO ........................ 100

APÊNDICE C CROMATOGRAMA DO PETRÓLEO: CARVÃO ATIVO ..................................... 101

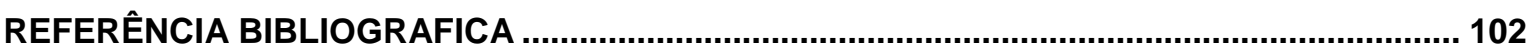




\section{LISTA DE FIGURAS}

Figura 1. Esquema da refinaria de petróleo simplificado(Speight, 2002) .............16

Figura 2. Classificação do petróleo segundo o tipo de hidrocarboneto ................18

Figura 3. Diagrama esquemático da radiólise da água ........................................39

Figura 4. Cromatógrafo a gás associado ao espectrômetro de massa acoplado com um concentrador de amostras do tipo "purge and trap". .............................57

Figura 5. Espectrômetro de Fluorescência de Raios-X por energia dispersiva......57

Figura 6. Espectroscopia de infravermelho com acessório de refletância total

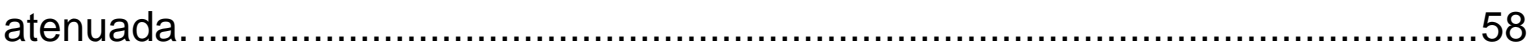

Figura 7. Separação química do diesel em coluna cromatográfica aberta.............59

Figura 8. Destilador de baixa pressão de acordo com ASTM 1160....................60

Figura 9. Separação do destilado de petróleo por cromatografia de coluna aberta

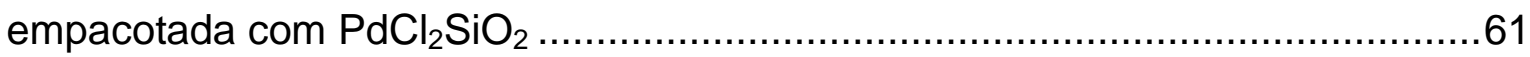

Figura 10. Esquema de separação do destilado de petróleo por cromatografia de coluna aberta empacotada com carvão ativo..................................................61

Figura 11. Cromatograma do benzotiofeno obtido no GC-MS associado ao concentrador de amostras do tipo "purge and trap".

Figura 12. Curva de calibração do BT obtida no GC-MS após pré-concentração em sistema Purge and Trap.

Figura 13. Remoção do benzotiofeno em função da dose absorvida de radiação

Figura 14. Concentração do BT em metanol em função da dose absorvida.........65 Figura 15. Compostos formados pela degradação de BT pela radiação ionizante.

Figura 16. Variação da área do pico dos principais compostos aromáticos e alifáticos no diesel com a dose absorvida de radiação.

Figura 17. Variação da área do pico dos principais compostos aromáticos e alifáticos no diesel com a dose absorvida de radiação, sem o metilnaftaleno. .....70 Figura 18. Variação da área do pico dos principais compostos nitrogenados no diesel em função da dose absorvida de radiação.

Figura 19. Variação da área do pico dos principais compostos sulfurados no diesel em função da dose absorvida de radiação .... 76

Figura 20. Variação da temperatura no fundo e topo da coluna com diferentes doses de irradiação.

Figura 21. Variação da temperatura no topo da coluna com a temperatura fixa e diferentes doses de radiação.

Figura 22. Variação da área do pico dos principais compostos sulfurados no petróleo, separados por coluna de cloreto de paládio, em função da dose absorvida de radiação

Figura 23. Variação da área do pico dos principais compostos sulfurados no petróleo, separados por coluna de carvão ativo, em função da dose absorvida de radiação 
Figura 24.Relação entre a área e a dose dos hidrocarbonetos no petróleo..........91 Figura 25. Relação entre a área e a dose dos compostos de nitrogênio no petróleo.

Figura 26. Espectros de infravermelho do petróleo irradiado e destiladas. .96 


\section{LISTA DE TABELA}

Tabela 1. Composição elementar do óleo cru.................................................17

Tabela 2. compostos sulfurados presentes no petróleo.......................................22

Tabela 3. Compostos nitrogenados presentes no petróleo ..................................24

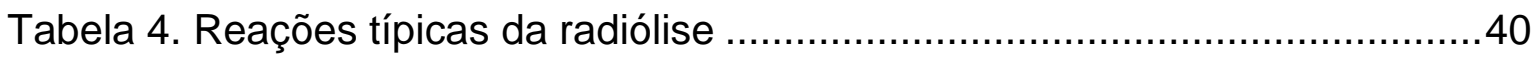

Tabela 5. Concentração de enxofre molecular total na amostra de diesel não irradiada e após a irradiação.

Tabela 6. Compostos orgânicos alifáticos e aromáticos identificados nas amostras de diesel após separação em carvão ativo.

Tabela 7. Degradação e /ou formação de hidrocarbonetos (\%) na amostra de diesel após a irradiação

Tabela 8. Compostos orgânicos nitrogenados identificados nas amostras de diesel.

Tabela 9. Degradação e /ou formação de compostos nitrogenados (\%) na amostra de diesel após a irradiação.

Tabela 10. Compostos orgânicos sulfurados identificados nas amostras de diesel

Tabela 11. Degradação e /ou formação de compostos sulfurados (\%) na amostra de diesel após a irradiação.

Tabela 12.Concentração de enxofre molecular total nas amostras de petróleo não irradiada e irradiada com diferentes doses.

Tabela 13. Teor de enxofre nas amostras de petróleo destilados em relação a dose de radiação

Tabela 14. Compostos orgânicos sulfurados identificados nas amostras de petróleo após separação cromatográfica usando cloreto de paládio.

Tabela 15. Remoção de compostos de enxofre (\%) da amostra de petróleo após a irradiação com 30 kGy e 50 kGy de doses absorvidas

Tabela 16 . Compostos orgânicos sulfurados identificados nas amostras de petróleo após separação cromatográfica usando carvão ativo.

Tabela 17. Remoção de compostos sulfurados (\% ) da amostra de petróleo após

a irradiação

Tabela 18. Principais hidrocarbonetos identificados nas amostras de petróleo destilado após separação cromatográfica usando cloreto de paládio.

Tabela 19. Remoção de compostos de enxofre (\% ) da amostra de petróleo após a irradiação

Tabela 20. Compostos orgânicos nitrogenados identificados nas amostras de petróleo.

Tabela 21. Remoção de compostos nitrogenados (\%) da amostra de petróleo após a irradiação... 


\section{INTRODUÇÃO}

O petróleo é considerado uma das principais fontes de energia e a sua importância ultrapassa a sua utilização como combustível ou como matéria prima para a indústria petroquímica, impulsionando de forma representativa a economia mundial. Atualmente o petróleo é produzido por todos os continentes, com exceção da Antártica e possui diferentes composições de acordo com a região e a profundidade em que foi extraído.

Após a extração, o petróleo passa por processos de refino, que, dependendo das características e composição do cru, envolve a destilação, a adsorção, a filtração e a extração por solventes. Após a separação tem-se a conversão, ou seja, craqueamento e polimerização e por fim o óleo passa por um tratamento químico, cujo objetivo é a remoção de constituintes indesejáveis (Hilsdorf, 2004).

Em virtude da importância que o refino tem para a indústria, tanto para a petrolífera quanto para a petroquímica, cada vez mais, novas tecnologias são acopladas a este processo a fim de aperfeiçoa-lo. Atualmente as pesquisas visam otimizar o processo de craqueamento e diminuir a quantidade de compostos de enxofre no petróleo, como uma alternativa mais eficiente em comparação a processos já em vigor na indústria. Compostos de enxofre e nitrogênio geram problemas ambientais, sendo os mais relevantes, a poluição da atmosfera que afeta a saúde da população diretamente e o aumento da acidez das chuvas(Mariano, 2001).

Existem, basicamente, duas tecnologias para dessulfurização do petróleo, numa delas os compostos sulfurados são reduzidos a $\mathrm{H}_{2} \mathrm{~S}$, sendo este posteriormente removido do produto e transformado em enxofre elementar; a segunda linha pressupõe a oxidação das espécies sulfúricas presentes no óleo, seguido de extração das moléculas maiores de compostos sulfúricos que foram oxidadas. No entanto, esse processo é relativamente difícil, pois é necessário atingir um alto nível de oxidação do enxofre. Ambas as abordagens e as suas 
combinações vêm sendo estudadas em conjunto com a aplicação da radiação como método para dessulfurização do petróleo(Zaykin, 2004, 2007).

Algumas pesquisas nesta área demonstraram que o processamento por irradiação reduz consideravelmente as concentrações de mercaptanos, dissulfetos e sulfetos em produtos de óleo pesado, oxidando esses compostos em sulfóxidos e sulfonas. Em outros estudos a utilização de feixes de elétrons em conjunto com ozônio reduziu o teor de enxofre numa amostra de óleo bruto, sendo removido posteriormente através da formação de uma solução aquosa de sulfonas ( National Energy Technology Laboratory, 2006; Zaykin, 2007; Zaykina, 2004).

Tendo em vista que a utilização da radiação ionizante em processos para redução de enxofre no petróleo ainda não está totalmente consolidada, novas pesquisas devem ser conduzidas a fim de elucidar este processo e avaliar a sua viabilidade econômica.

\subsection{Legislação}

A legislação ambiental brasileira baseia-se muitas vezes no que é praticado tanto na Europa quanto nos Estados Unidos, exemplo disto é a que regula o teor de enxofre no diesel. O teor de enxofre nos combustíveis é alvo de constantes debates, grande parte deles visa a redução drástica da quantidade de enxofre emitido por veículos através da queima de combustível. Como resultado desses debates, novas especificações são criados, sendo o mais recente delas as medidas assinadas pela Agencia Nacional do Petróleo, Gás Natural e Biocombustíveis (ANP), Resolução no 38 e no-42 ambas de 2009.(Jorge, 2007)

Em 2009, a ANP publicou a resolução no 42, nesta estabeleceu-se que o teor de enxofre no diesel a partir de 2013 deveria ser de $10 \mathrm{mg} \cdot \mathrm{Kg}^{-1}$ e a resolução $n^{\circ} 38$ da ANP estabeleceu as especificações da gasolina com limite máximo de $50 \mathrm{mg} \cdot \mathrm{Kg}^{-1}(\mathrm{ANP}, 2009)$ 
Neste mesmo ano o diesel comercializado nas regiões do interior passou de $2000 \mathrm{mg} / \mathrm{kg}$ para $1.800 \mathrm{mg} / \mathrm{kg}$ de teor de enxofre e nas regiões metropolitanas, no máximo, $500 \mathrm{mg} / \mathrm{kg}$ de teor de enxofre. Entretanto em algumas regiões metropolitanas do Brasil podia se encontrar o diesel $50 \mathrm{mg} / \mathrm{kg}$ (S50). A partir de 2013, o óleo diesel S10 passou a substituir o S50 e, em 2014, para uso rodoviário, o S500 passou a substituir o óleo diesel S1800. Desta forma o Brasil começa a se equiparar a outros países que possuem combustíveis com baixos teores de enxofre, como os europeus com $10 \mathrm{mg} / \mathrm{Kg}$ e os Estados Unidos com 15 mg/Kg. (Silva et al. 2013; Vialli; 2008).

Outras novas propostas que visam melhorar a qualidade dos combustíveis continuarão surgindo, isto porque estudiosos também já advertem para a necessidade de que esta redução vá além das propostas (Jorge, 2007).

\subsection{Processo de refino do petróleo}

Refinarias possuem unidades de processamento interligadas com 0 propósito de produzir produtos derivados do petróleo. Cada refinaria possui um arranjo próprio que está diretamente relacionado à composição do petróleo (Speight, 2002, 2006).

De modo geral, o processo de refino pode ser dividido em três grupos principais, que são a separação ou fracionamento, que baseia-se na divisão dos compostos do petróleo por destilação; a conversão, destinada à produção de derivados, geralmente por alteração do esqueleto das moléculas carbônicas ou alteração química dos constituintes do petróleo e o acabamento, que consiste essencialmente na purificação por processos de remoção ou transformação dos contaminantes(Machado, 2011; Speight, 2002).

Na destilação, que é a unidade mais importante no processamento do petróleo, frações básicas do refino são separadas, de acordo com sua volatilidade, em diferentes intervalos de temperaturas. Com o aumento dos pontos de ebulição ocorre também o aumento dos pesos moleculares, de modo que, com 
- aquecimento do petróleo ocorre a vaporização de compostos leves, intermediários e pesados que ao condensarem, podem ser separados(Speight, 2001, 2002, 2006).

Após a destilação, cada fração é encaminhada para outras unidades de processamento com 0 intuito de purificar os diferentes produtos para que os mesmos estejam dentro de determinadas especificações (Machado, 2011; Speight, 2001, 2002, 2006).

O processo de destilação é dividido em dois estágios, que são a destilação atmosférica e a destilação a vácuo. Na destilação atmosférica, as frações são recolhidas por ordem crescente de densidade, sendo o ponto de ebulição dos cortes mais pesados obtidos à pressão atmosférica e limitados pela temperatura de $350^{\circ} \mathrm{C}$. Nesta etapa também ocorre a formação do resíduo pesado, chamado de resíduo atmosférico, que é retido na base da torre, pois nas condições de temperatura e pressão atmosférica não se vaporiza. Este resíduo é então submetido à destilação a vácuo(Machado, 2011; Speight, 2001, 2002, 2006).

O resíduo atmosférico é um corte de alto peso molecular, que é submetido a outra destilação sob pressão menor que a atmosférica, com o intuito de evitar o craqueamento térmico. Nesta fração são obtidos os gasóleos leves e os pesados (Machado, 2011; Speight, 2001, 2002, 2006).

Na Figura 1 é apresentado um esquema simplificado da refinaria de petróleo, onde é possível ter uma visão geral do processo com as suas respectivas faixas de ebulição e os produtos resultantes. 


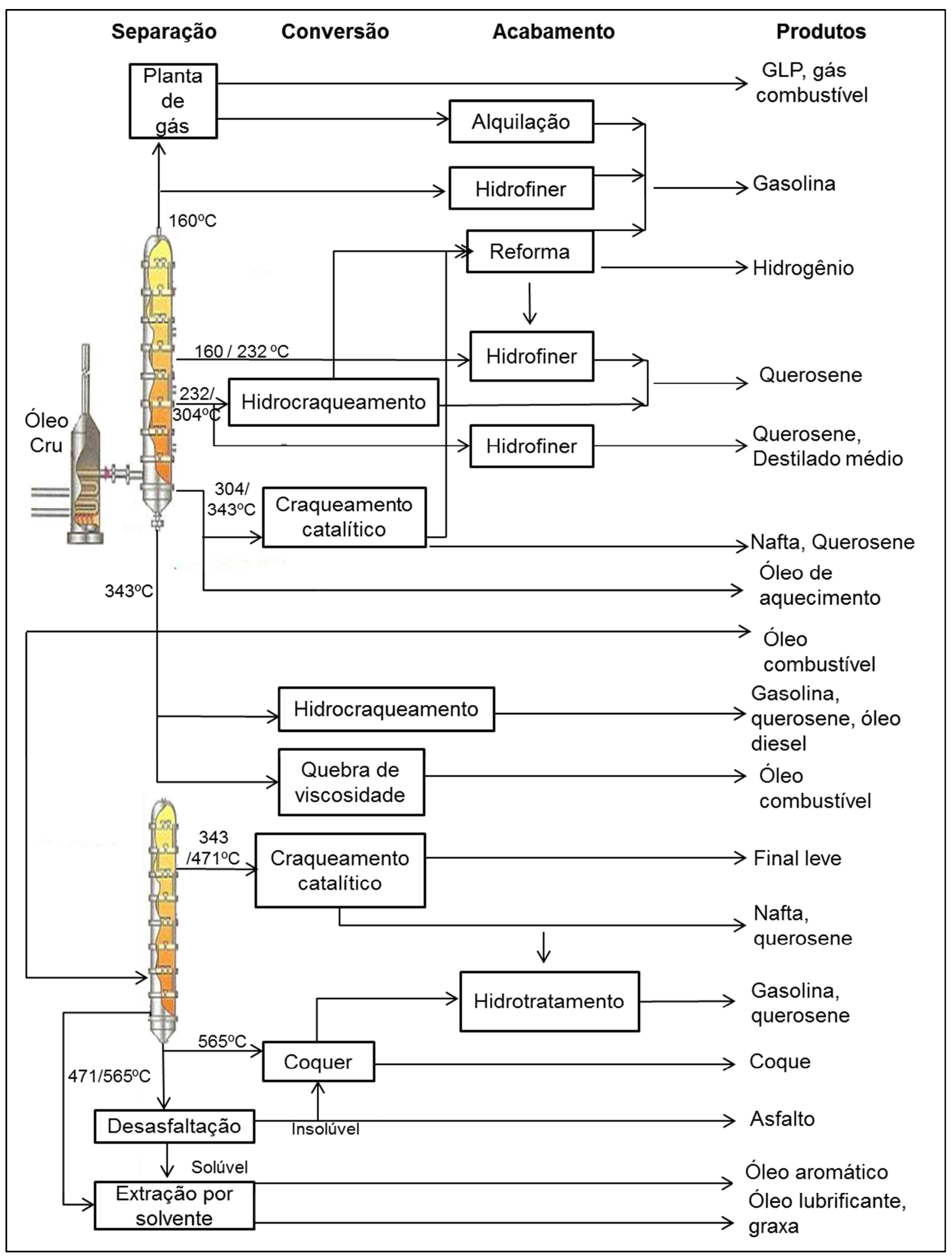

Figura 1. Esquema da refinaria de petróleo simplificado(Speight, 2002). 


\subsection{Características e composição do petróleo}

A palavra petróleo é derivada do latim petra(pedra) e oleum (óleo), as suas características variam de acordo com o reservatório do qual foi extraído, basicamente é caracterizado por ser oleoso em seu estado liquido, inflamável, de cheiro pronunciado, menos denso que a água e com cores que variam desde 0 amarelo até o preto. Possui viscosidade variável, o peso especifico pode variar de 0,77 a $0,98 \mathrm{Kg} \cdot \mathrm{L}^{-1}$, o seu poder calorífico varia de 9.700 a $11.700 \mathrm{Kcal} . \mathrm{Kg}^{-}$ ${ }^{1}$ (Hilsdorf, 2004; Lemberck, 2010; Thomas, 2001; Speight, 2006).

O petróleo é constituído por uma mistura de compostos químicos orgânicos, conhecidos como hidrocarbonetos. Quando esta mistura é composta de moléculas pequenas, seu estado físico é gasoso e quando a mistura possui moléculas grandes seu estado físico é liquido, nas condições normais de temperatura e pressão. Também pode apresentar compostos contendo elementos minerais, tais como o níquel e o vanádio e ainda algumas impurezas, como a água e materiais inorgânicos como $\mathrm{S}, \mathrm{N}_{2}, \mathrm{O}_{2}$, e outros metais, Tabela 1 (McCain Jr., 1990;Thomas, 2001).

Tabela 1. Composição elementar do óleo cru

\begin{tabular}{cl}
\hline Elemento & $\%$ em peso \\
\hline Hidrogênio & $11-14$ \\
Carbono & $83-87$ \\
Enxofre & $0,06-8$ \\
Nitrogênio & $0,11-1,7$ \\
Oxigênio & $0,1-2$ \\
Metais & até $0,3 \%$ \\
\hline
\end{tabular}

Fonte: (Speight, 2001)

Os hidrocarbonetos que constituem o óleo são agrupados em diferentes séries de compostos e cada série é constituída de compostos que possuem estruturas moleculares e propriedades semelhantes. Com as series definidas, existe um grande espectro de compostos que variam desde os 
extremamente leves ou hidrocarbonetos simples, como o $\mathrm{CH}_{4}$, até os pesados ou complexos, como é o caso do $\mathrm{C}_{40} \mathrm{H}_{82}$;

\subsection{Classificação do petróleo}

De um modo geral, a composição do petróleo pode ser estudada por dois métodos que são o químico e o físico.

\subsubsection{Classificação química}

O petróleo pode ser classificado de acordo com o hidrocarboneto predominante. Esta classificação ajuda na escolha adequada do processo de refino do óleo cru e na sua finalidade (McCain Jr, 1990; Thomas, 2001).

Os constituintes majoritários do óleo cru e de seus produtos são os hidrocarbonetos, ou seja, hidrogênio e carbono. No Figura 2 é apresentado um esquema da classificação química simplificada de acordo com o tipo de hidrocarboneto.

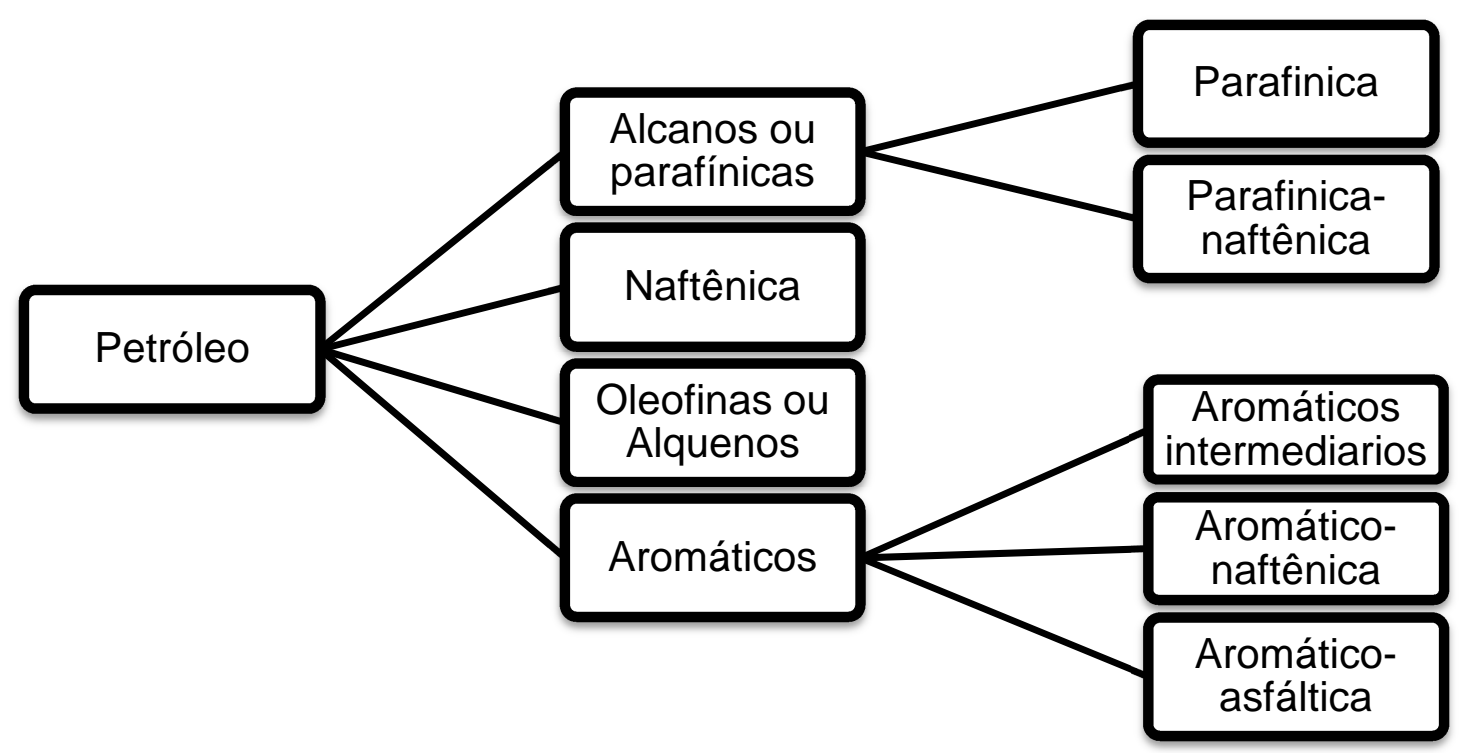

Figura 2. Classificação do petróleo segundo o tipo de hidrocarboneto 


\subsubsection{Classe parafínica ( $75 \%$ ou mais de parafinas)}

$\mathrm{Na}$ classe parafínica encontra-se os óleos leves, fluidos ou de alto ponto de fluidez, com densidade abaixo de 0,85 , teor de resinas e asfaltenos menores que $10 \%$ e baixa viscosidade, com exceção aos casos em que o teor de n-parafinas com alto peso molecular é elevado, sendo que isto gera como consequência um alto ponto de fluidez. Os aromáticos presentes são anéis simples ou duplos e o teor de enxofre é baixo. Essas características faz com que os parafínicos sejam indicados para a produção de querosene de aviação, diesel, lubrificantes e parafinas. A maior parte do petróleo produzido no Nordeste brasileiro pertence à esta classe(McCain Jr, 1990; Thomas, 2001).

\subsubsection{Classe parafínico - naftênicos $(50-70 \%$ parafinas, $>20 \%$ de naftênicos)}

Os óleos desta classe possuem teor de resinas e de asfaltenos que variam de 5 e $15 \%$, possuem baixo teor de enxofre (menos de 1\%) e teor de naftênicos entre 25 e $40 \%$. Sua densidade e viscosidade são ligeiramente maiores se comparados aos parafínicos. Grande parte do petróleo produzido na Bacia de Campos, RJ, pertence a esta classe(McCain Jr, 1990; Thomas, 2001).

\subsubsection{Classe Naftênica ( $>70 \%$ de naftênicos)}

Os óleos naftênicos apresentam baixo teor de enxofre e se originam da alteração bioquímica de óleos parafínicos e parafínico-naftênicos. Estes produzem frações significativas de gasolina, nafta petroquímica, querosene de aviação e lubrificantes. Somente alguns óleos da América do Sul, Rússia e Mar do Norte pertencem a essa classe(McCain Jr, 1990; Thomas, 2001).

\subsubsection{Classe aromática intermediária $(>50 \%$ de hidrocarbonetos a aromáticos)}

Os aromáticos intermediários são óleos pesados, que contem de 10 a $30 \%$ de asfaltenos e resinas, seu teor de enxofre é acima de $1 \%$. O teor de 
monocromáticos é baixo, entretanto o teor de tiofenos e dibenzotiofenos são elevados, normalmente, possui densidade maior que 0,85. Óleos da Arábia Saudita, Catar, Kuwait, Iraque, Síria, Turquia, África Ocidental, Venezuela, Califórnia, Sicília, Espanha e Grécia fazem parte desta classe(McCain Jr, 1990; Thomas, 2001).

\subsubsection{Classe aromático-naftênica ( $>35$ de naftênicos)}

Os óleos desse grupo passaram por um processo inicial de biodegradação, no qual foram removidas as parafinas. São derivados dos óleos parafínicos e parafínico-naftênicos, podendo conter mais de $25 \%$ de resinas e asfaltenos, seus teor de enxofre varia entre 0,4 e 1\%, Alguns óleos da África Ocidental são desse tipo(McCain Jr, 1990; Thomas, 2001).

\subsubsection{Classe aromáticos - asfáltica ( $>35 \%$ de asfaltenos e resinas)}

Os aromáticos-asfáltico são óleos provenientes de um processo de biodegradação avançada em que ocorre a reunião de monocicloalcenos e oxidação. Nestes também é possível encontrar alguns óleos verdadeiramente aromáticos não degradados da Venezuela e África Ocidental. Contudo esta classe compreende majoritariamente óleos pesados e viscosos, resultantes dos óleos aromáticos intermediários(McCain Jr, 1990; Thomas, 2001).Portanto o teor de asfaltenos e resinas é elevado, o teor de enxofre varia de 1 a $9 \%$. Nesta classe encontram-se os óleos do Canadá ocidental, Venezuela e sul da França (McCain Jr, 1990; Thomas, 2001).

\subsubsection{Não hidrocarbonetos}

O petróleo possui uma elevada quantidade de impurezas, que aparecem em diferentes faixas de ebulição, contudo tendem a se concentrar nas frações mais pesadas. Dentre os principais não hidrocarbonetos encontra-se o enxofre, o nitrogênio, o oxigênio e os metais(McCain Jr., 1990; Speight, 2001; Thomas, 2001). 
Embora a concentração destes compostos não hidrocarbonetos sejam pequenas em certas frações do petróleo, estes, ainda assim, tem sua importância. Por exemplo, a deposição da suspensão de sais inorgânicos no óleo cru pode causar sérias avarias nas operações da refinaria; a decomposição térmica de cloretos inorgânicos, gerando acido clorídrico pode gerar sérios problemas nos equipamentos de destilação. A presença de compostos ácidos, como mercaptanas e ácidos pode também causar corrosão de metais. No processo catalítico, o envenenamento de catalisadores pode ser causada pela deposição de traços de metais como o vanádio e o níquel, ou pela quimissorção dos compostos de nitrogênio que estão presentes catalisador, levando à necessidade de regeneração frequente do catalisador ou a sua substituição(McCain Jr., 1990; Speight, 2001; Thomas, 2001).

A presença de traços de não hidrocarbonetos causa um grande impacto nas características dos produtos finais, como descoloração, pouca estabilidade no armazenamento, ou a redução da eficácia dos aditivos antidetonantes. Desta forma fica evidente que um conhecimento mais extensivo sobre estes compostos e de suas características podem resultar numa otimização na qualidade do produto final(McCain Jr., 1990; Speight, 2001; Thomas, 2001).

\subsubsection{Compostos sulfurados}

O enxofre é o terceiro elemento químico mais abundante no petróleo, sua concentração media é de $0,65 \%$ em peso, com uma faixa apresentando valores entre 0,02 e 4,00\%, cabe ressaltar que tais concentrações de enxofre variam de acordo com a origem do petróleo, geralmente, quanto maior a densidade do petróleo, maior será o teor de enxofre (McCain Jr., 1990; Speight, 1999, 2001; Thomas, 2001).

O enxofre está presente no petróleo nas formas de sulfetos, polisulfetos, benzotiofenos e derivados, moléculas policíclicas com nitrogênio e oxigênio, gás sulfídrico, dissulfeto de carbono, sulfeto de carbonila e enxofre elementar (muito raro)(McCain Jr., 1990; Speight, 1999, 2001; Thomas, 2001). Na 
Tabela 2 são apresentados os principais compostos sulfurados presentes no petróleo.

Tabela 2. compostos sulfurados presentes no petróleo.

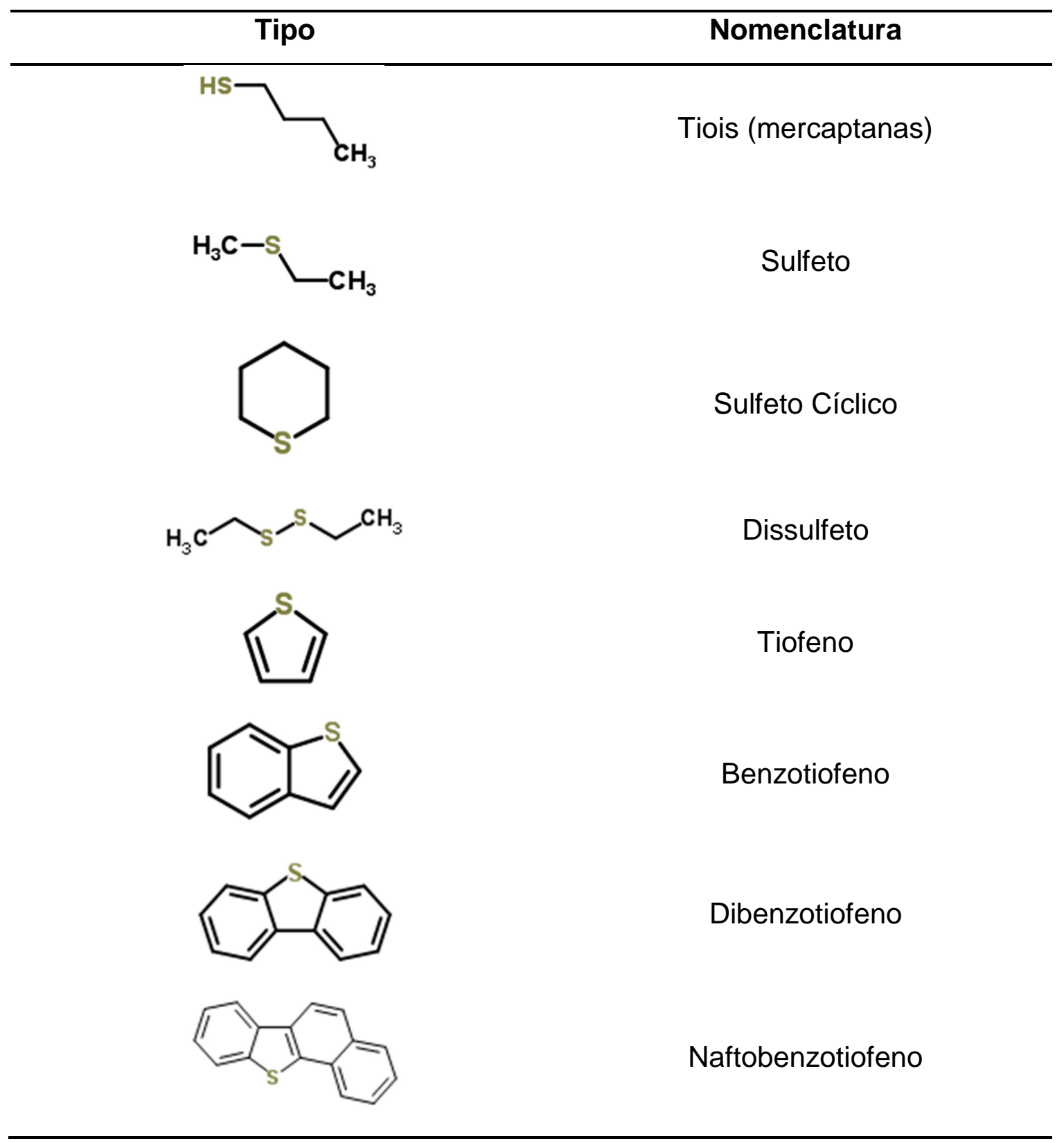

Fonte: Speight, 2001.

Esses compostos são amplamente utilizados como matéria prima para a obtenção de acido sulfúrico, produto químico mais fabricado no mundo. Nas refinarias de petróleo o enxofre elementar é basicamente obtido através do processo de Claus. Dentre as aplicações do enxofre pode-se citar o aditivo de asfalto; os cimentos e os concretos de enxofre, o tratamento de vegetação e solo, 
bateria de enxofre e metal alcalino e o isolamento de espuma de enxofre(Santos, 2005).

Apesar de ter inúmeras utilidades, o enxofre é considerado um elemento indesejável em qualquer combustível. Estes aumentam a poluição ambiental, através da contaminação da atmosfera pela oxidação do enxofre resultante da queima de combustíveis, formando dióxido de enxofre, que posteriormente será oxidado por raios ultravioletas a $\mathrm{SO}_{3}$. Esses compostos interagem com a água da atmosfera gerando a chuva ácida, que tem ação corrosiva no meio ambiente, particularmente para as plantas e vida aquática. $\mathrm{O}$ $\mathrm{SO}_{2}$ pode danificar folhas causando manchas descoloradas, áreas branqueadas entre veias, clorose e lesão em insetos. Além disto, esses compostos causam inúmeros problemas em estruturas feitas pelo homem tais como prédios e pontes e a corrosão do solo(Jarullah, 2011; Kowalewska, 2011;Jr, 2004; Medeiros, 2003; Thomas, 2001).

A presença de compostos sulfurados na indústria também causa inúmeros problemas, tais como a corrosão em equipamentos metálicos, a contaminação de catalisadores utilizados nos processos de dessulfurização e a precipitação de sedimentos. Além disso aumentam a polaridade dos óleos e, consequentemente, a estabilidade das emulsões, afetam os aditivos adicionados à gasolina com o intuito de aumentar o número de octanos, como o chumbo tetraetila, determinam a qualidade, cor e o cheiro dos produtos finais, desvalorizando-os (Jarullah, 2011; Kowalewska, 2011; Jr, 2004; Medeiros, 2003; Thomas, 2001).

A concentração total de enxofre é expressa em porcentagem por peso ou ppm sendo este determinado experimentalmente em amostras de óleo ou nos produtos. A concentração de enxofre no petróleo é levada em consideração juntamente com o grau API para a determinação de seu valor comercial. Alguns estudos relacionam o peso do óleo com a concentração de enxofre diretamente, ou seja quanto maior o peso do óleo bruto maior o teor de enxofre também(AbdelAal, 2003; Speight 2001, 2006). 


\subsubsection{Compostos oxigenados}

Os compostos oxigenados aparecem no petróleo de uma forma relativamente complexa, tais como os ácido carboxílicos, fenóis, cresóis, ésteres, amidas, cetonas e benzofuranos. Tendem a se concentrar nas frações mais pesadas e são responsáveis pela acidez, coloração, odor, formação de gomas e corrosividade das frações do petróleo. A concentração total de oxigênio no petróleo geralmente é menor do que 2\% em massa (McCain Jr., 1990; Speight, 2001; Thomas, 2001).

\subsubsection{Compostos nitrogenados}

O nitrogênio apresenta-se no petróleo basicamente na forma orgânica, são termicamente estáveis e são classificados como básico e não básico. Os compostos básicos são majoritariamente homólogos de piridina e tendem a existir nas frações cujos pontos de ebulição são mais elevados. Os compostos não básicos, como os pirróis, indóis e tipos de carbozol também ocorrem nestas frações. Na Tabela 3 são apresentados os compostos nitrogenados presentes no petróleo(McCain Jr., 1990; Speight, 2001; Thomas, 2001).

Tabela 3. Compostos nitrogenados presentes no petróleo

Formula Estrutural Não Básicos




\section{Benzocarbazol}

\section{Básicos}

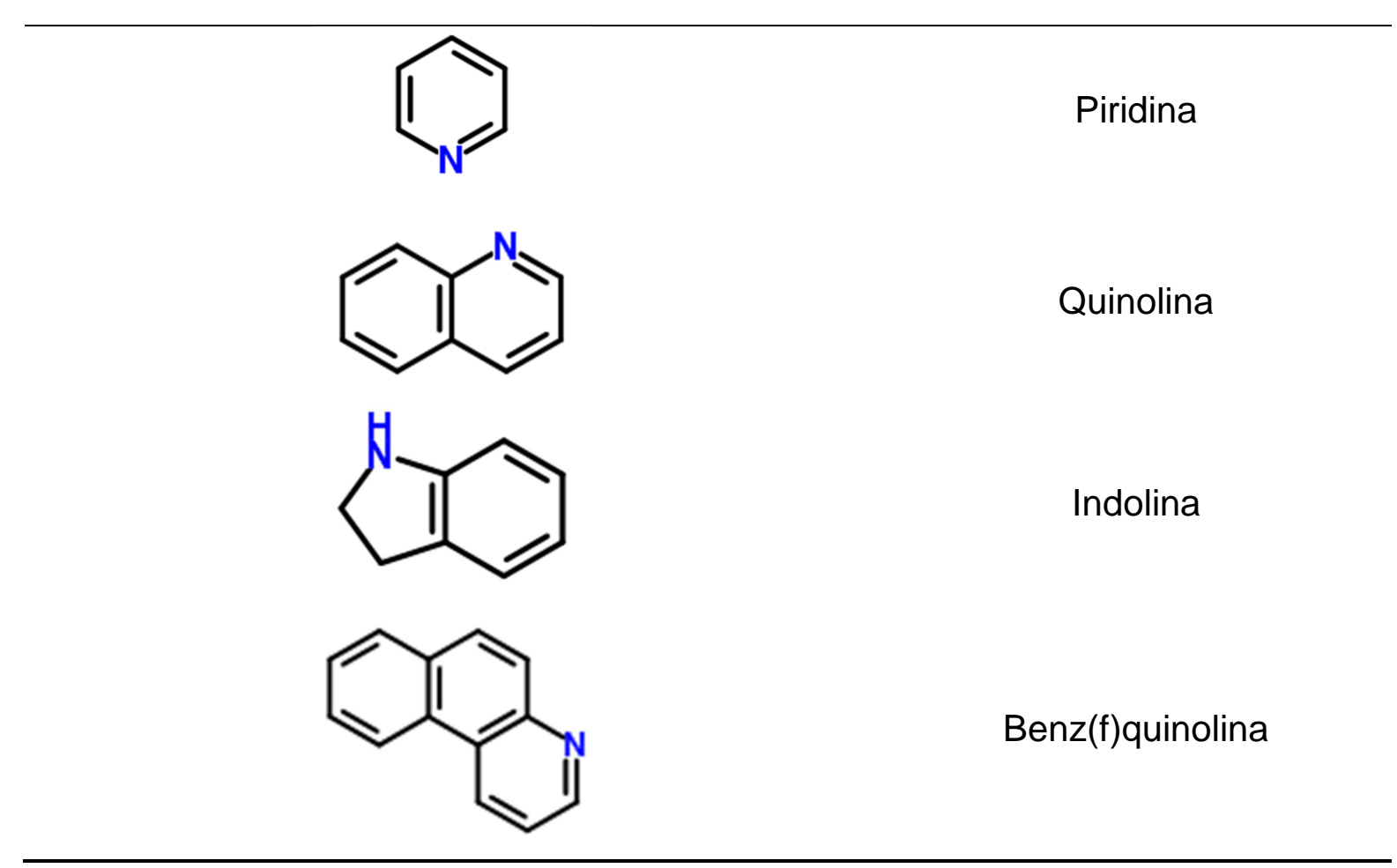

Fonte: (Thomas, 2001)

A concentração de compostos de nitrogênio no óleo cru é baixa, variando de 0,1 até $0,9 \%$, contudo é comum não ser detectado ou até mesmo ser detectado somente como traços, geralmente estes compostos são encontrados nos óleos asfálticos. Apesar de suas baixas concentrações, durante o refino o nitrogênio torna-se instável, sendo um dos responsáveis pelo envenenamento dos catalizadores de fracionamento, assim como influenciam a estabilidade dos combustíveis durante a estocagem, Alquilindóis estão associados com a formação de sedimentos em diesel combustível e com a alteração da coloração(Speight, 2001; Thomas, 2001).

O nitrogênio é determinado em peso (ppm) em uma amostra, sua presença no petróleo contribui negativamente nos processos catalíticos, pois age envenenando os mesmos. Da mesma forma que $0{ }^{\circ} \mathrm{API}$ se relaciona ao teor de enxofre no petróleo, também existe um a correlação do API com o teor de 
nitrogênio, que segue a correlação aproximada entre a concentração de nitrogênio e a quantidade de resíduo de carbono, ou seja, quanto maior a quantidade de resíduo de carbono maior a quantidade de nitrogênio (Speight, 2001, 2006)

\subsubsection{Metais}

O arsênio, o níquel e o vanádio são envenenadores dos processos de catalise, até mesmo traços desses metais pode causar corrosão ou afetar a qualidade dos produtos do refino. (Abdel-Aal, 2003; Speight 2001, 2006).

\subsubsection{Métodos físicos}

Pelos métodos químicos, os compostos químicos são identificados individualmente no óleo cru. Por outro lado, os métodos físicos consideram o óleo cru e seus produtos como uma mistura de hidrocarbonetos e se utiliza de testes físicos para caracterizar e qualificar o óleo.

Para que seja possível utilizar tal classificação devemos ter em mente que óleos crus de diferentes locais podem variar na aparência, na viscosidade e ainda na forma de se obter o produto final. É possível identificar, através de determinados testes físicos, a qualidade óleo que será extraído. Tais testes serão descritos a seguir.

\subsubsection{Densidade, peso especifico e Grau API}

Para melhor compreensão deste tópico faz-se necessário expor algumas definições básicas que serão utilizadas, como a densidade é a massa de um liquido por unidade de volume, esta tem dimensões de gramas por centímetros cubicos; (2) densidade relativa é a razão entre a massa de um dado volume de um liquido em $15^{\circ} \mathrm{C}$ sobre a massa de um mesmo volume de agua pura na mesma temperatura; (3) peso especifico possui a mesma definição da 
densidade relativa de forma que ambos termos são utilizados intercaladamente. (Abdel-Aal, 2003; Speight, 2001, 2006).

Antigamente, a densidade era a principal forma de especificação para os produtos do petróleo e foi muito utilizada pela indústria como método preliminar de caracterização e qualificação do óleo cru, além do fato de ser utilizada como base na compra e venda. Entretanto, as relações derivadas entre a densidade e a composição fracionada somente eram válidas se aplicadas a um determinado tipo de petróleo. Desta forma o American Petroleum Institute (API) criou o API para medir a densidade relativa de óleos e derivados (Abdel-Aal, 2003; Speight, 2001, 2006).

Petróleos com ำAPI maior que 32 são considerados leves, aqueles que se encontram entre $24^{\circ}$ e 31 , são médios, os que possuem valores abaixo de 23 são considerados pesados e os igual ou inferior a 10 são extrapesados. $O$ óleo leve é constituído majoritariamente de hidrocarbonetos alifáticos, que são mais facilmente degradados pela população microbiana do óleo pesado, que geralmente tem concentrações elevadas de hidrocarbonetos aromáticos (AbdelAal, 2003; Speight, 2001, 2006).

\subsubsection{Viscosidade}

A viscosidade é a medida da resistência que um liquido tem de fluir, indicando, no caso do óleo, a o grau de "bombeamento" que este possui. Geralmente é determinada em diferentes temperaturas, através da medição do tempo que um volume de líquido demora para fluir através de um viscosímetro capilar de vidro calibrado(Abdel-Aal, 2003; Speight, 2001, 2006).

\subsubsection{Ponto de fluidez}

O ponto de fluidez é definido como a menor temperatura $\left(5^{\circ} \mathrm{F}\right)$ na qual o óleo ira fluir sob condições especificas. Geralmente, os óleos aromáticos têm o 
menor ponto de fluidez e quanto maior o ponto de fluidez mais parafínico o óleo será(Abdel-Aal, 2003; Speight, 2001, 2006).

\subsubsection{Pressão de vapor Reid}

A pressão de vapor Reid, RPV, é a medida da pressão do vapor exercida pelo óleo ou por produtos leves a 100F,(Abdel-Aal, 2003; Speight 2001, 2006). Essa propriedade mede a tendência de bolhas de vapor serem produzidas na linha de combustível também indica os riscos de explosão e evaporação do combustível (Fahim, 2012).

\subsection{Tratamentos para redução de enxofre}

Para a obtenção de produtos com propriedades comercializáveis, o petróleo passa por etapas como os tratamentos químicos, que são utilizados para eliminar ou reduzir as concentrações de impurezas, principalmente aquelas que provêm de compostos que contém enxofre, nitrogênio e oxigênio em suas moléculas. Tais tratamentos são realizados, pois dependendo do processo e da qualidade do óleo cru, os derivados obtidos podem acabar não se enquadrando nas especificações requeridas, principalmente quando se trata do teor de enxofre (Mariano, 2001; Petrobras, 2002). Os tratamentos químicos podem ser divididos em duas classes, que são os processos de adoçamento e os processos de dessulfurização.

Os processos de adoçamento têm por finalidade transformar compostos de enxofre que são considerados agressivos, como é o caso do $\mathrm{S}$, $\mathrm{H}_{2} \mathrm{~S}$ e RSH, em outros menos prejudiciais, como por exemplo, em RSSR' dissulfetos, isso sem os retirar dos produtos finais, em outras palavras, o teor do enxofre permanece constate. Os processos mais conhecidos são: Tratamento Doctor(tratamento já obsoleto) e o Tratamento Bender. (Mariano, 2001; Petrobras, 2002). 
Nos processos de dessulfuração, os compostos de enxofre são removidos dos produtos. Dentre esses processos tem-se a lavagem cáustica, o tratamento com dietanolamina (DEA)e a dessulfurização catalítica, que está em desuso (Mariano, 2001; Petrobras, 2002).

Alternativa tanto para adoçamento como para dessulfurização é o Tratamento Merox, que vem sendo utilizado em larga escala.

\subsubsection{Tratamento Bender}

O tratamento Bender é um processo de adoçamento, no qual os compostos de enxofre que são mais agressivos são transformados em composto menos agressivos, sem alterar o teor do enxofre no produto, tal processo é aplicado às frações intermediárias do petróleo como a nafta, o querosene e o óleo diesel, o principal objetivo deste tratamento é melhorar a qualidade do querosene de aviação (Mariano, 2001; Petrobras, 2002).

Esse tratamento consiste, fundamentalmente, na oxidação catalítica, que ocorre em um reator de leito fixo, onde as mercaptanas que são corrosivos serão convertidas em dissulfetos, que são menos agressivos, a reação ocorre em meio alcalino, na presença de ar e enxofre elementar que são utilizados como agentes oxidantes. $O$ catalisador desse processo é à base de óxido de chumbo. No inicio do processo tem-se uma carga que é aquecida e posteriormente misturada com soda cáustica, em seguida a corrente resultante passa por uma válvula misturadora que promove um contato maior entre a carga e a soda, formando uma emulsão. Esta emulsão não deve permanecer no processo, então é introduzida num precipitador eletrostático, onde um campo elétrico da ordem de 20.000 V facilitará a quebra da emulsão e a separação das fases cáustica e orgânica. A solução cáustica acumula-se no fundo do vaso e a fase orgânica sai pelo topo. Este procedimento denomina-se lavagem cáustica e tem como finalidade remover compostos ácidos como, por exemplo, fenóis, ácidos naftênicos e $\mathrm{H}_{2} \mathrm{~S}$, que são considerados interferentes no processo de adoçamento (Mariano, 2001; Petrobras ,2002). 
Após o procedimento de lavagem cáustica, a carga é dividida em duas correntes, onde a de menor vazão segue para a parte superior de um vaso denominado torre absorvedora de enxofre. Ao passar pela torre a carga absorve enxofre necessário às reações, em seguida a carga enriquecida reúne-se na corrente principal. Tendo o teor de enxofre absorvido regulado, a carga recebe uma injeção de ar comprimido e penetra no fundo do reator Bender. No interior deste há um leito fixo de catalisador ( $\mathrm{PbS}$ ), que faz com que as reações de adoçamento ocorram. No topo do reator é injetado soda cáustica para que o meio reacional mantenha-se alcalino (Mariano, 2001; Petrobras, 2002).

As reações que ocorrem no tratamento de Bender são:

\section{$2 \mathrm{R}-\mathrm{SH}+1 / 2 \mathrm{O} 2 \rightarrow \mathrm{RSSR}+\mathrm{H}_{2} \mathrm{O}$ \\ $2 \mathrm{R}-\mathrm{SH}+\mathrm{S}+2 \mathrm{NaOH} \rightarrow \mathrm{RSSR}+\mathrm{Na}_{2} \mathrm{~S}+2 \mathrm{H}_{2} \mathrm{O}$}

O efluente do reator sai pelo topo do mesmo e em seguida recebe uma injeção de água de processo, que tem como função retirar a soda cáustica e as impurezas que foram arrastadas. A mistura resultante é submetida a um turbilhonamento e depois vai para um vaso de lavagem com água. Tal vaso é um precipitador eletrostático, como o que foi descrito anteriormente, sendo que neste tem-se a separação da fase aquosa e do produto (Mariano, 2001; Petrobras, 2002).

\subsubsection{Lavagem cáustica}

A lavagem cáustica é basicamente utilizada para remoção de mercaptanas e $\mathrm{H}_{2} \mathrm{~S}$, contudo também é utilizada para remoção de compostos ácidos que possam estar presentes no derivado a ser tratado, de modo geral esse tratamento só é aplicado quando o teor de enxofre é relativamente pequeno (Mariano 2001; Petrobras 2002).Este processo é realizado para tratar frações leves, ou seja, aquelas que possuem densidades bem menores que a da solução cáustica, como por exemplo, o GLP e a nafta (Mariano, 2001; Petrobras 2002). 
Inicialmente a carga recebe um solução aquosa de $\mathrm{NaOH}$ com uma concentração que varia de 15 a $20 \%$ e passa por uma válvula misturadora, onde a carga e a solução entram em contato intimo. Após a mistura a concentração da soda que circula continuamente, diminui gradativamente até atingir um mínimo que varia de 1 a $2 \%$ e pela diferença de densidade tem se a separação das fases, a qual ocorre em um vaso decantador, onde a fração do petróleo sai pelo topo do vaso e a solução cáustica pouco concentrada sai pelo fundo, a lavagem cáustica pode ser repetida (Mariano, 2001; Petrobras, 2002).

As quantidades de estágios de lavagem cáustica vão depender diretamente do teor de enxofre no derivado. Outra opção é a lavagem aquosa, que pode ser utilizada com estágio final, evitando que a soda seja arrastada pelo produto (Mariano, 2001; Petrobras, 2002).

As reações destes processos são as seguintes:

$$
\begin{aligned}
& 2 \mathrm{NaOH}+\mathrm{H}_{2} \mathrm{~S} \rightarrow \mathrm{Na}_{2} \mathrm{~S}+2 \mathrm{H}_{2} \mathrm{O} \\
& \mathrm{NaOH}+\mathrm{RSH} \rightarrow \mathrm{NaSR}+\mathrm{H}_{2} \mathrm{O} \\
& \mathrm{NaOH}+\mathrm{R}-\mathrm{COOH} \rightarrow \mathrm{R}-\mathrm{COONa}+\mathrm{H}_{2} \mathrm{O}
\end{aligned}
$$

\subsubsection{Tratamento com dietanolamina, DEA}

$\mathrm{O}$ tratamento com DEA é um processo aplicado para remoção de $\mathrm{H}_{2} \mathrm{~S}$ do gás combustível, do gás natural e do gás liquefeito, de modo que estas frações possam estar de acordo com as especificações relacionadas ao teor de enxofre e à corrosividade. Esse tratamento possui a vantagem de remover também o dióxido de carbono $\left(\mathrm{CO}_{2}\right)$ (Mariano, 2001; Petrobras, 2002).Um dos aspectos importantes desse processo é a capacidade de regenerar a DEA que foi utilizada na remoção de $\mathrm{H}_{2} \mathrm{~S}$.

Neste processo as soluções de etanolaminas combinam com o $\mathrm{H}_{2} \mathrm{~S}$, gerando produtos estáveis a temperaturas próximas a do ambiente e ao serem aquecidos acabam se decompondo, regenerando desta forma a solução de DEA 
e liberando uma corrente ácida, rica em enxofre, que em seguida é recuperado numa unidade de recuperação de enxofre (Mariano, 2001; Petrobras, 2002).

\subsubsection{Tratamento Merox}

O tratamento merox é um processo moderno, aplicado a frações leves como é o caso do GLP e da nafta e também a frações intermediárias como o querosene e o diesel. Este tratamento se baseia na extração cáustica de mercaptanas que se encontram nos derivados, que em seguida são oxidados a dissulfetos, ao mesmo tempo em que a solução cáustica é regenerada. Toda reação ocorre na presença de um catalisador organometálico (ftalocioanina de cobalto). Esse catalisador pode tanto estar em leito fixo quanto dissolvido em solução de soda cáustica (Mariano, 2001; Petrobras, 2002).

A utilização do catalisador em leito fixo é caracterizada como um processo de adoçamento que ocorre quando a carga é mais pesada, ou seja, querosene e diesel, sendo que a oxidação, neste caso, ocorre simultaneamente com a extração, de modo que os dissulfetos não são retirados do derivado (Mariano, 2001; Petrobras, 2002).

O processo no qual o catalisador fica dissolvido em solução cáustica é caracterizado por ser um processo de dessulfurização. que diminui muito o teor de enxofre. Este é aplicado a frações leves, onde a extração e a oxidação ocorrem em etapas diferentes, retirando-se os dissulfetos do derivado. Basicamente o produto a ser tratado sofre, inicialmente, uma lavagem cáustica, onde $\mathrm{O} \mathrm{H}_{2} \mathrm{~S}$ e os compostos ácidos são eliminados, esse procedimento é realizado a fim de evitar a formação de compostos estáveis na seção de extração. Nesta etapa de pré-lavagem, o tempo de contato entre a carga e a solução cáustica é curto, portanto as mercaptanas não chegam a ser absorvidas. Posteriormente a carga segue para uma torre extratora, onde a presença do catalisador em solução e o tempo de contato promovem a remoção das mercaptanas. A carga entra pelo fundo da torre, escoando em contracorrente com a solução cáustica com o catalisador(Mariano, 2001; Petrobras, 2002). 
No contato entre a solução cáustica e a carga, as mercaptanas são removidas de acordo com a seguinte reação:

\section{$\mathrm{RSH}+\mathrm{NaOH} \rightarrow \mathrm{RSNa}+\mathrm{H}_{2} \mathrm{O}$}

No topo da torre tem-se a saída do produto tratado, que segue para um vaso decantador, onde qualquer resquício de soda que houver, fica retido. Neste ponto o derivado já esta apto para ser estocado e comercializado (Mariano, 2001; Petrobras, 2002)

No fundo da torre de extração tem-se a saída de soda, junta se a corrente que foi recuperada no decantador, esta é aquecida e recebe uma injeção de ar comprimido e em seguida é enviada para uma torre onde ocorre sua regeneração, nesta torre ocorre a seguinte reação:

\section{$4 \mathrm{NaOH}+2 \mathrm{H}_{2} \mathrm{O}+\mathrm{O}_{2} \stackrel{\text { Cat. }}{\longrightarrow} 4 \mathrm{NaOH}+2$ RSSR}

Após a regeneração, a mistura que contém soda, ar e dissulfetos passam para um vaso onde ocorre a separação por decantação, no fundo do vaso, a solução cáustica regenerada é removida e enviada novamente para a torre de extração, enquanto no topo do vaso ocorre a saída do ar (Mariano, 2001; Petrobras, 2002)

No tratamento merox um efluente oleoso de dissulfetos sai do separador.

\subsubsection{Hidrotratamento, Hidrodessulfurização e Hidrodesnitrogenação}

O hidrotratamento, HDT, um dos métodos mais utilizados pelas refinarias de petróleo, é um processo utilizado com intuito de remover impurezas de diversos cortes do petróleo, tais como enxofre, nitrogênio, oxigênio, haletos e traços de metais, através de reações de hidrogenação, na presença de um 
catalisador em alta temperatura e alta pressão. Também tem como objetivo melhorar a qualidade das frações, pois converte mono e di-oleofinas em parafinas, desta forma tem-se a redução da formação de goma nos combustíveis (Mariano, 2001; Speight, 1999).

No caso especifico de remoção de enxofre, o processo passa a ser denominado de hidrodessulfurização,,HDS. A hidrodessulfurização ocorre na seção de conversão da refinaria (hidrocraqueameto) ou na seção final do processo de refinação (hidrotratamento) (Mariano, 2001; Speight,1999).

O processo de hidrodessulfurização pode ser destrutivo, neste caso o processo requer alta temperatura e alta pressão de hidrogênio, sendo caracterizado pela clivagem da ligação carbono-carbono e é acompanhada pela saturação de hidrogênio de fragmentos a fim de se obter produtos com pontos de ebulição mais baixos, sendo que o enxofre orgânico presente na matéria prima é convertido para sulfeto de hidrogênio (Mariano, 2001; Speight, 1999).

A hidrodessulfurização também ocorre de forma não destrutiva, de forma que o processo de hidrogenação tem o intuito de melhorar a qualidade do produto sem alterar o ponto de ebulição, logo, não há clivagem das ligações carbono-carbono em virtude das condições mais brandas de temperatura e pressão, de forma que o enxofre é removido na forma de sulfeto de hidrogênio (Mariano, 2001; Speight, 1999).

O HDS mostra-se eficiente na remoção de tióis, sulfetos e dissulfetos, contudo é menos efetiva para tiofenos e derivados do tiofeno. Como a maioria dos compostos que se mantém nos fluidos de transporte são tiofenos, benzotiofeno, dizenzotiofenos e seus alquis derivados, a dessulfurização por HDS torna-se muito difícil e cara, pois demanda muita energia, tais como altas temperaturas $\left(>300^{\circ} \mathrm{C}\right)$ e pressões que podem chegar a $2 \times 10^{7} \mathrm{~Pa}$, além do alto consumo de hidrogênio e de catalisador de cobalto e molibdênio, que encarecem o processo. Outro fator negativo deste processo é a saturação de compostos olefinicos, resultando numa perda de octanagem em cerca de 10 vezes(HernándezMaldonado, 2005; Salem,1994). 
A remoção do nitrogênio ocorre através da hidrodesnitrogenação, HDN, que trata piridinas, quinoleínas, isoquinoleínas, pirróis, indóis e carbazóis, com liberação de $\mathrm{NH}_{3}$, este tratamento é aplicado simultaneamente ao HDS. Entretanto, a capacidade dos compostos de nitrogênios adsorverem ao catalisadoré mais elevada quando comparada com o derivado do tiofeno aromático, isto gera competição pelos sítios do catalisador. Outro fator se refere a velocidade de reação, pois o HDN é um processo lento e isto faz com que o nitrogênio permaneça no sitio do catalisador, dificultando a conversão dos compostos sulfurados (Lissner, 2012; Mühlen,2007).

\subsection{Aplicação da Radiação lonizante}

A tecnologia nuclear tem sido usada na proteção e conservação do meio ambiente, seu emprego na destruição de compostos orgânicos tóxicos presentes em amostras ambientais, água potável, remediação de solos e efluentes industriais têm sido objeto de estudo de vários autores no Brasil e no mundo (Duarte, 1999).

Em estudos para tratamento de efluentes industriais, a irradiação com feixe de elétrons mostrou-se eficiente na degradação dos compostos orgânicos principalmente o benzeno, tolueno, xileno e fenol, presentes em efluentes da produção de petróleo(Duarte, 2002, 2004).

Em relação ao petróleo, alguns estudos foram realizados para compreender de que forma o radiação interage com este material e também, de que forma ela pode contribuir para a redução dos compostos de enxofre e para o craqueamento. Para a melhor compreensão desta seção, uma breve explanação sobre as fontes de radiação e a interação da radiação com a matéria será apresentada. 


\subsubsection{Fontes de radiação ionizante}

Há diversas aplicações da radiação ionizante, tanto em pesquisas quando nas indústrias, um delas é como processo de oxidação avançada, onde dois tipos de irradiadores são utilizados, os que emitem raios gama, como Cobalto-60, aplicado em larga escala em pesquisas e os aceleradores de elétrons, que predominam em processos industriais(Duarte, 1999; Wojnárovits, 2003)

As fontes de radiação gama são usadas em processos que requerem maior penetração da radiação, suas instalações são compostas por paredes espessas de concreto que servem como blindagem. Esta fonte geralmente é utilizada para a esterilização de produtos médicos e irradiação de alimentos (Duarte, 1999).

Acelerados de modo geral são preferidos como fontes de radiação para aplicações ambientais. A taxa de dose, o rendimento energético elevado, o licenciamento simplificado e o sistema liga-desliga são as principais vantagens desta fonte. Por outro lado, a baixa penetração da radiação e a necessidade de operadores especializados são apontadas como as principais desvantagens (Duarte,1999).

\subsubsection{Interação da radiação com a matéria}

A radiação ionizante proveniente de fontes de raios gama ou aceleradores de elétrons interagem com a matéria transferindo sua energia para os átomos e moléculas do meio. Num intervalo de tempo extremamente pequeno, da ordem de $10^{-13}$ s a $10^{-2}$, tem- se a primeira fase da interação, na qualse observa o efeito físico da radiação, no qual a troca de energia entre a radiação e a matéria resulta na ionização e excitação dos átomos(Duarte, 1999; Woods, 1998).

Numa segunda fase têm-se os efeitos químicos, que levam à ruptura de ligações moleculares e a formação de radicais livres. Esses efeitos ocorrem 
em um intervalo de tempo de aproximadamente $10^{-9} \mathrm{~s}$ (Duarte, 1999; Woods, 1998).

A interação da radiação com a matéria pode ocorrer através de dois mecanismos, que são o direto e o indireto. No mecanismo direto a radiação atua diretamente nas moléculas em questão, no indireto a radiação interage com as moléculas de água, formando espécies químicas altamente reativas e difusíveis, que interagiram com a matéria do meio. Um dos mecanismos mais relevantes da interação da radiação com a matéria é a radiólise da água(Duarte, 1999; Wojnárovits et al., 2003; Woods, 1998).

A relação da quantidade de energia transferida pela radiação ionizante para a matéria em uma determinada massa, é definida como dose absorvida. Esta grandeza é valida para todos os tipos de radiação ionizante e para qualquer material absorvedor. A unidade definida pelo Sistema Internacional de medidas para dose absorvida é o joule por quilograma $\left({\left.\mathrm{J} . \mathrm{Kg}^{-1}\right)}^{-}\right.$ou Gray, anteriormente chamado de rad, essas grandezas podem ser convertidas através da seguinte relação (Duarte, 1999; Wojnárovits et al., 2003; Woods,1998):

$$
(1 \mathrm{rad}=100 \mathrm{ergs} / \mathrm{s} ; 1 \mathrm{~Gy}=100 \mathrm{rad})
$$

O rendimento de produtos químicos ou íons produzidos pela radiação é definido como a razão da quantidade de produtos produzidos pela dose absorvida. Em química das radiações tal rendimento é denominado de G cuja unidade é $\mathrm{mol} / \mathrm{J}$ e significa número de radicais, moléculas ou íons que são formados ou destruídos em uma solução, após a absorção de 100 eV de energia incidente (Duarte, 1999; Wojnárovits et al., 2003; Woods, 1998).

\subsubsection{Radiólise da água}

Quando uma solução aquosa é irradiada, as moléculas de água sofrem decomposição, originando os produtos da radiólise. Após a decomposição, a $\mathrm{H}_{2} \mathrm{O}$ é quase totalmente ionizada formando $\mathrm{H}_{2} \mathrm{O}^{+}+\mathrm{e}^{-}$, e parcialmente excitada sendo 
decomposta em $\mathrm{H}+{ }^{\circ} \mathrm{OH}$ (ou $\mathrm{H}_{2}+\mathrm{O}$ ), esta fase denomina-se estágio físicoquímico. Este estágio ocorre em regiões próximas às posições na qual a energia foi depositada. $\mathrm{O}$ cátion $\mathrm{H}_{2} \mathrm{O}^{+}$interage prontamente com a água ao seu redor, originando a radical hidroxila, $\mathrm{OH}$ e o elétron ( $\mathrm{e}^{-}$) ejetado desta reação é solvatado pela $\mathrm{H}_{2} \mathrm{O}$ para formar o $e^{-}$aq. Sequencialmente os produtos da radiólise, $\mathrm{e}_{\text {aq. }}^{-} \mathrm{H}, \mathrm{OH}, \mathrm{H}_{3} \mathrm{O}^{+}$e $\mathrm{H}_{2}$, são formados em $10^{-12} \mathrm{~s}$ após a deposição de energia(Duarte,1999; Nagaishi,2011; Rashed, 2005; Wojnárovits, 2003).

Tendo em vista que os produtos da radiólise não são distribuídos uniformemente, na fase seguinte ao estagio físico-químico, os produtos são difundidos e simultaneamente reagem uns com os outros, isto ocorre por sua alta reatividade e concentração local. Posteriormente os radicais $e_{\text {aq. }}^{-} \mathrm{H}, \mathrm{OH}, \mathrm{H}_{3} \mathrm{O}^{+}$, $\mathrm{H}_{2}, \mathrm{H}_{2} \mathrm{O}$ que escaparam ou foram formados na reação impulsionadora, são distribuídos homogeneamente em $10^{-7}$ s após a deposição de energia, nesta fase o rendimento do produtos são denominados de rendimentos primários. Por fim os produtos são envolvidos na reação de homogeneidade, que é denominado de estagio químico(Nagaishi,2011; Rashed, 2005; Wojnárovits, 2003).

$\mathrm{O}$ comportamento e o rendimento da produção de $\mathrm{H}_{2}$ na radiólise da água dependem do estagio físico-químico (deposição da energia da radiação e decomposição da água) e do estagio químico (escoamento da água e homogeneidade da reação). Os dois tipos de deposição de energia ocorrem na fase físico-química como demonstrados no esquema da Figura 3. 


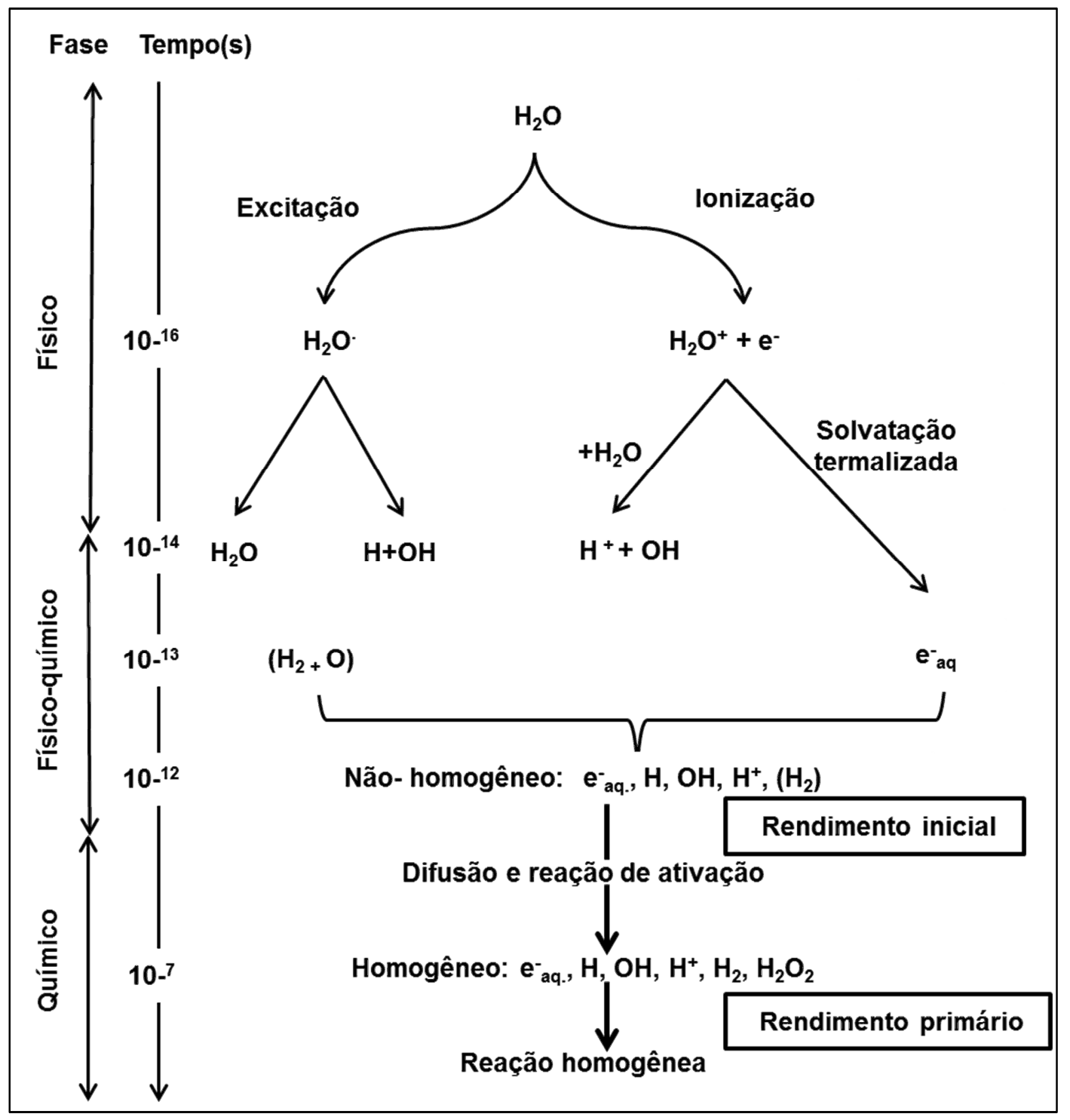

Fonte:(Nagaishi, 2011)

Figura 3. Diagrama esquemático da radiólise da água

\subsubsection{Reações induzidas pela radiação}

Os produtos resultantes da radiólise da água são distribuídos de forma homogênea e interagem com compostos orgânicos e inorgânicos presentes no material de forma que os produtos resultantes dependem da sua composição química(Duarte, 1999; Nagaishi,2011; Rashed, 2005). Na Tabela 4 são listadas as reações típicas da radiólise com suas constantes de reação. 
Tabela 4. Reações típicas da radiólise

\begin{tabular}{|c|c|c|}
\hline & Produtos & Constantes $\left(10^{10} \mathrm{M}^{-1} \mathrm{~s}^{-1}\right)$ \\
\hline $\begin{array}{l}\mathrm{e}_{\mathrm{aq}}^{-}+\mathrm{e}_{\mathrm{aq}}^{-}\left(+2 \mathrm{H}_{2} \mathrm{O}\right) \\
\mathrm{e}_{\mathrm{aq}}^{-}+\mathrm{H}^{\circ}\left(+\mathrm{H}_{2} \mathrm{O}\right) \\
\mathrm{e}_{\mathrm{aq}}^{-}+\mathrm{OH} \\
\mathrm{e}^{-} \mathrm{Oq}+\mathrm{H}_{2} \mathrm{O}_{2} \\
\mathrm{e}^{-} \mathrm{aq}^{+}+\mathrm{H}^{+} \\
\mathrm{H}^{-}+\mathrm{H}^{\cdot} \\
\mathrm{H}^{-}+{ }^{\circ} \mathrm{OH} \\
\mathrm{H}^{+}+\mathrm{H}_{2} \mathrm{O}_{2} \\
{ }^{\circ} \mathrm{OH}+{ }^{\circ} \mathrm{OH} \\
\cdot \mathrm{OH}+\mathrm{H}_{2} \\
{ }^{\circ} \mathrm{OH}+\mathrm{H}_{2} \mathrm{O}_{2} \\
\mathrm{e}_{\mathrm{aq}}^{-}+\mathrm{O}_{2} \\
\mathrm{H}^{-}+\mathrm{O}_{2}\end{array}$ & $\begin{array}{l}\rightarrow \mathrm{H}_{2}+2 \mathrm{OH}^{-} \\
\rightarrow \mathrm{H}_{2}+\mathrm{OH}^{-} \\
\rightarrow \mathrm{OH}^{-} \\
\rightarrow \mathrm{OH}^{-} \mathrm{OH}^{-} \\
\rightarrow \mathrm{H}^{\circ} \\
\rightarrow \mathrm{H}_{2} \\
\rightarrow \mathrm{H}_{2} \mathrm{O} \\
\rightarrow \mathrm{OH}^{\circ}+\mathrm{H}_{2} \mathrm{O} \\
\rightarrow \mathrm{H}_{2} \mathrm{O}_{2} \\
\rightarrow \mathrm{H}^{\circ}+\mathrm{H}_{2} \mathrm{O} \\
\rightarrow \mathrm{HO}_{2}+\mathrm{H}_{2} \mathrm{O} \\
\rightarrow 0^{\circ}{ }_{2} \\
\rightarrow \mathrm{HO}_{2}\end{array}$ & $\begin{array}{c}0.644 \\
2.64 \\
3.02 \\
1.41 \\
2.25 \\
0.543 \\
0.153 \\
0.00516 \\
0.474 \\
0.00415 \\
0.00287 \\
1.79 \\
1.32 \\
\end{array}$ \\
\hline
\end{tabular}

Fonte: Nagaishi,2011.

\subsubsection{Elétron aquoso $\left(\mathrm{e}_{\mathrm{aq}}^{-}\right)$}

A interação de compostos orgânicos e inorgânicos com elétron aquoso tem sido estudado durante anos. Este atua como um redutor altamente eficiente e na transferência de elétrons, sendo que sua interação com compostos halogenados são de grande importância (Duarte,1999; Rashed, 2005).

$$
\mathrm{e}_{\mathrm{aq}}^{-}+\mathrm{RCl} \rightarrow \mathrm{R}^{\cdot}+\mathrm{Cl}^{\circ}
$$

\subsubsection{2. Átomo de hidrogênio}

O radical hidrogênio, que também é um agente redutor, é produzido exclusivamente através do processo de oxidação avançada com feixes de elétrons. $\mathrm{O} \mathrm{H}^{\cdot}$ reage com compostos orgânicos por dois mecanismos, que são a adição ou a subtração de hidrogênio(Celina, 1999; Rashed, 2005).

Reação de adição:

$\mathrm{H}^{\circ}+\mathrm{C}_{6} \mathrm{H}_{6} \rightarrow \mathrm{C}_{6} \mathrm{H}_{7}$ 
Reação geral de subtração do $\mathrm{H}^{*}$ num átomo de metanol:

\section{$\mathrm{H}^{\cdot}+\mathrm{CH}_{3} \mathrm{OH} \rightarrow \mathrm{H}_{2}+{ }^{\circ} \mathrm{CH}_{2} \mathrm{OH}$}

A reação de abstração geralmente ocorrem em compostos orgânicos saturados, já as reações de adição tendem a ocorrer em compostos insaturados e aromáticos(Celina, 1999; Rashed, 2005).

\subsubsection{Radical hidroxila $\mathrm{OH}$}

O radical hidroxila é um dos principais agentes oxidantes formados na irradiação da água e pode interagir, através de diferentes mecanismos, com compostos químicos que estejam em solução aquosa. Os mecanismos de reação mais comuns são a adição, a subtração de hidrogênio, a transferência de elétrons e o rearranjo entre os radicais. A ocorrência de reações de adição é observada na interação do $\mathrm{OH}$ com compostos aromáticos e alifáticos insaturados(Celina, 1999; Rashed, 2005).

\section{$\mathrm{OH}+\mathrm{CH}_{2}=\mathrm{CH}_{2} \rightarrow \mathrm{HOCH}_{2}=\mathrm{CH}_{2}{ }^{\circ}$}

Reações de subtração são observadas tanto em moléculas saturadas e insaturadas pertencentesà classe dos aldeídos e cetonas:

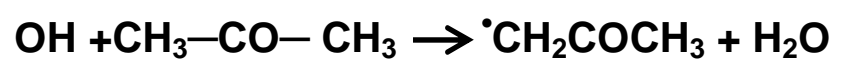

Já as reações de transferência de elétrons comumente ocorrem quando a solução aquosa é irradiada com elétrons de alta energia e geralmente envolvem íons halogênios, $X$ :

$$
\begin{aligned}
& \cdot \mathrm{OH}+\mathrm{X} \rightarrow \mathrm{X}^{\cdot}+\mathrm{OH} \\
& \mathrm{X}^{\cdot}+\mathrm{X}^{-} \rightarrow \mathrm{X}^{-}{ }_{2}
\end{aligned}
$$


$\mathrm{O} \mathrm{X}^{-}{ }_{2}$ pode interagir com moléculas orgânicas, resultando compostos orgânicos halogenados.

\subsubsection{Peróxido de hidrogênio}

A formação de $\mathrm{H}_{2} \mathrm{O}_{2}$ da-se principalmente a partir da recombinação entre radicais hidroxila(Celina, 1999; Rashed, 2005).

\section{$\cdot \mathrm{OH}+{ }^{\circ} \mathrm{OH} \rightarrow \mathrm{H}_{2} \mathrm{O}_{2}$}

A dissociação do peróxido de hidrogênio também pode ocorrer, assim mais radicais oxidantes são fornecidos para o meio.

$$
\mathrm{e}_{\mathrm{aq}}^{-}+\mathrm{H}_{2} \mathrm{O}_{2} \rightarrow{ }^{\cdot} \mathrm{OH}+\mathrm{OH}^{\cdot}
$$

\subsubsection{Interação da radiação com hidrocarbonetos saturados, insaturados e aromáticos.}

De modo geral, hidrocarbonetos simples são utilizados como molécula modelo para o estudo da radiólise dos hidrocarbonetos, a razão para isto está no fato de que compostos orgânicos simples fornecem reações modelos, que podem ser aplicadas a hidrocarbonetos mais complexos.

A partir de estudos com o gás metano, notou-se que a decomposição radiolítica resulta principalmente na formação de hidrogênio, etano, etileno e cadeias longas. Produtos semelhantes a polímeros também foram formados em menores concentrações (Wojnárovits,2003; Yang,1959).

A concentração de etileno e produtos com maior peso molecular é

altamente dependente das condições experimentais, principalmente sobre a conversão. Isto se deve à alta reatividade dos intermediários com os produtos finais do que com o próprio metano (Wojnárovits,2003; Yang,1959). O mecanismo desta interação é descrito a seguir: 


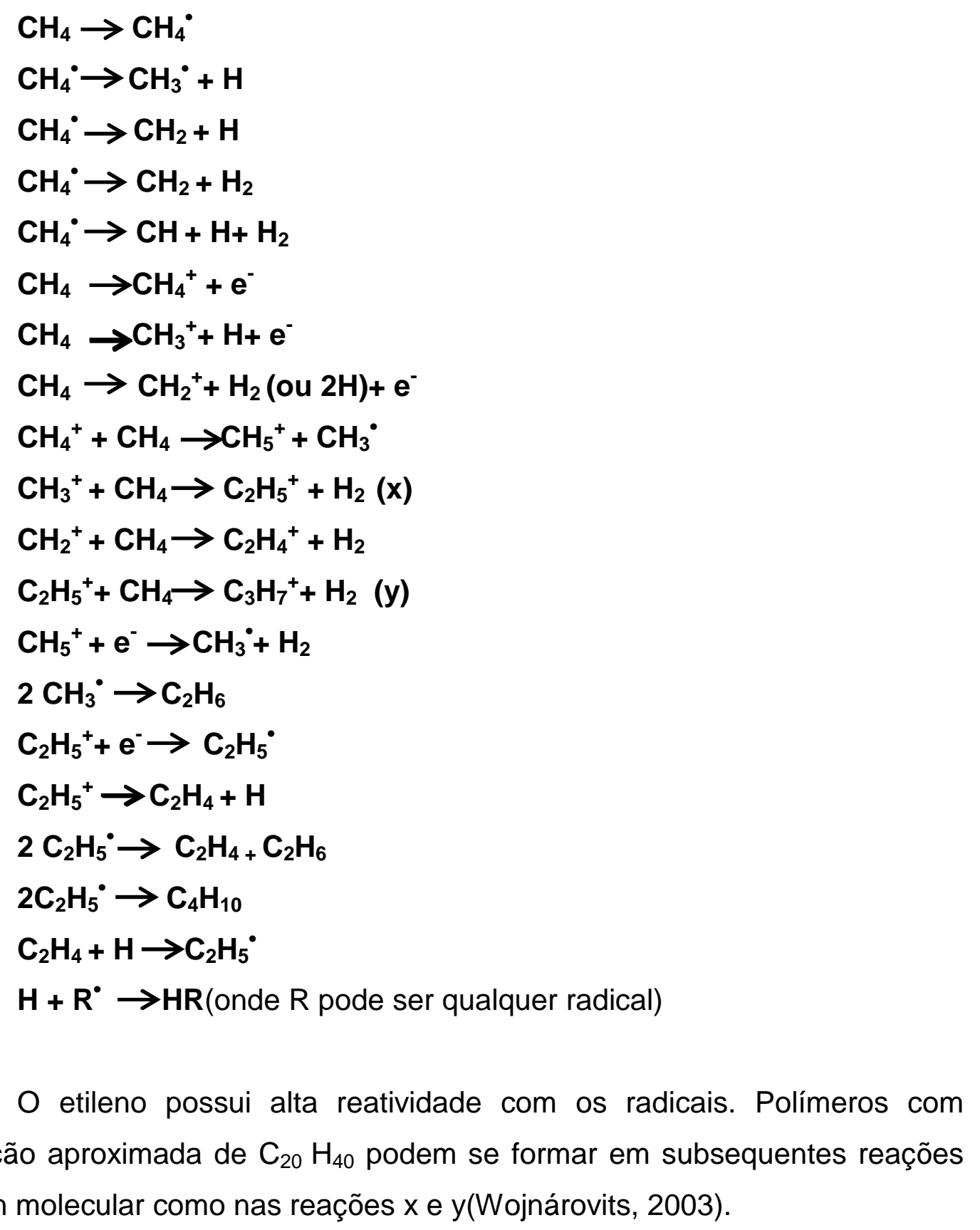

Ciclohexano á temperatura ambiente deve reagir da mesma forma que um alcano. Na molécula todas as ligações C-C e C-H são idênticos e consequentemente o produto de distribuição é relativamente simples, hidrogênio, ciclohexeno com deficiência de hidrogênio e biciclohexil são os principais produtos de degradação(Földiák, 1980; Wojnárovits, 2003)

$$
\begin{aligned}
& c-\mathrm{C}_{6} \mathrm{H}_{12} \rightarrow c-\mathrm{C}_{6} \mathrm{H}_{12}{ }^{+\cdot}+\mathrm{e}^{-} \\
& c-\mathrm{C}_{6} \mathrm{H}_{12} \rightarrow c-\mathrm{C}_{6} \mathrm{H}_{12}
\end{aligned}
$$




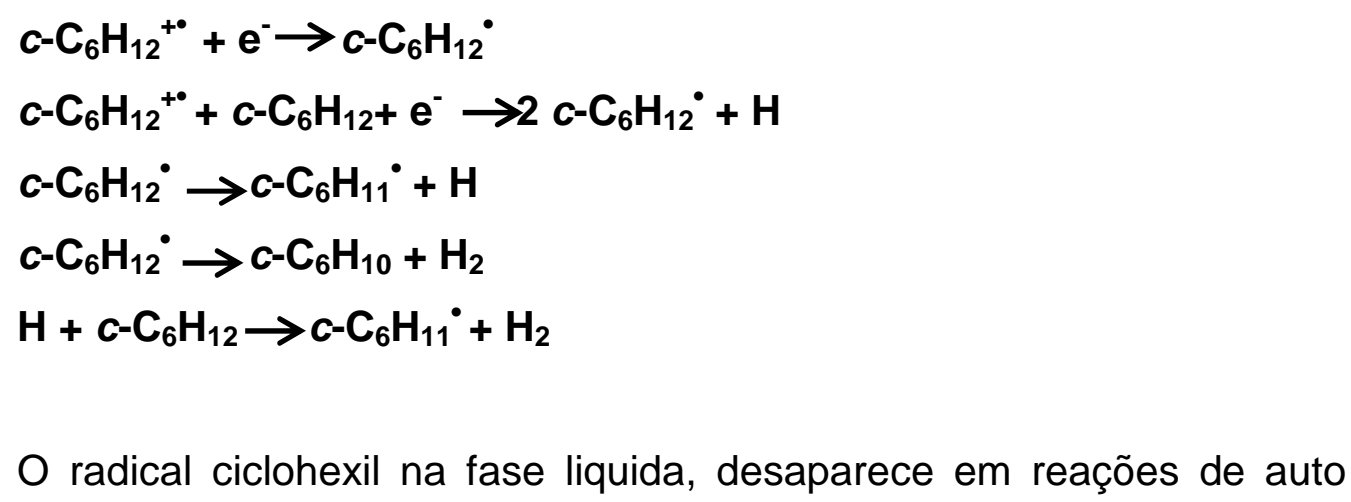
terminação, formando ciclohexeno e biciclohexil na proporção de 1:1 como pode ser observado nas equações z e w.

\section{$2 c-\mathrm{C}_{6} \mathrm{H}_{11} \rightarrow c-\mathrm{C}_{6} \mathrm{H}_{10}+c-\mathrm{C}_{6} \mathrm{H}_{12}(\mathrm{z})$$$
2 c-\mathrm{C}_{6} \mathrm{H}_{11} \rightarrow\left(c-\mathrm{C}_{6} \mathrm{H}_{11}\right)_{2}(w)
$$

$\mathrm{Na}$ radiólise de $\mathrm{n}$-alcanos, tanto o teor de hidrogênio quanto a decomposição ligações C-C permanecem essencialmente constantes quando o numero de carbonos aumenta de $\mathrm{C}_{4}$ para $\mathrm{C}_{17}$. Ainda deve-se notar que a decomposição das ligações $\mathrm{C}-\mathrm{H}$ e C-C não ocorrem de forma randômica. A frequência da decomposição da ligação $\mathrm{C}-\mathrm{H}$ no carbono secundário é três vezes maior do que em carbonos primários. A fragmentação ocorre preferencialmente na região central, portanto a eliminação de grupos metil é pouco frequente (Wojnárovits, 2003; Yang, 1959).

Na radiólise de alcanos ramificados, os produtos da decomposição de ligações $\mathrm{C}-\mathrm{H}$ são menores do que na radiólise de $\mathrm{n}$-alcanos, entretanto esta redução é compensada pelo aumento de produtos resultantes da quebra de C-C. Nestes alcanos a quebra da ligação $\mathrm{C}-\mathrm{H}$ ocorre preferencialmente nos carbonos terciários, 14 vezes mais do que em carbonos primários. A decomposição de ligações C-C ocorrem preferencialmente em carbonos terciários e quaternários (Wojnárovits, 2000; 2003).

Nos alquenos, as duplas ligações estabilizam a molécula diante da radiólise, consequentemente $o$ rendimento da decomposição primária e a quantidade de hidrogênio produzida é muito menor se comparada à 
decomposição dos alcanos. A baixa produção de hidrogênio é atribuída à facilidade de atração de átomos de H pelas duplas ligações (Wojnárovits, 2003).

$$
\begin{aligned}
& \mathrm{CH}_{2}=\mathrm{CH}-{ }^{1} \mathrm{R}+{ }^{2} \mathrm{R}^{\cdot} \rightarrow{ }^{2} \mathrm{R}-\mathrm{CH}_{2}-\mathrm{CH}-{ }^{-} \mathrm{R} \\
& \mathrm{CH}_{2}=\mathrm{CH}-{ }^{1} \mathrm{R}+{ }^{2} \mathrm{R}^{\cdot} \rightarrow{ }^{\circ} \mathrm{CH}_{2}-\mathrm{C}\left({ }^{2} \mathrm{R}\right) \mathrm{H}-{ }^{1} \mathrm{R}
\end{aligned}
$$

Os hidrocarbonetos aromáticos têm alta resistência à radiação, isto porque os elétrons $\pi$ são conjugados. O sistema conjugado redistribui a energia absorvida por toda a molécula, logo, a probabilidade da energia se localizar em uma única ligação é muito pequena. Os principais produtos formados a partir do benzeno e de outros hidrocarbonetos aromáticos são os dímeros e os compostos com alto peso molecular, ou seja, polímeros(Laverne, 1984; Wojnárovits, 2003).

Os anéis aromáticos podem agir como redutores de energia absorvida para outras cadeias ligadas ao anel, como mistura de hidrocarbonetos aromáticos e n-alcanos. Contudo observa-se um aumento na decomposição de cadeias ligadas ao anel aromático quando estas são longas (Wojnárovits, 2003).

\subsubsection{Craqueamento induzido por radiação em hidrocarbonetos}

O fenômeno mais importante na interação da radiação com hidrocarbonetos em alta temperatura e alta taxa de dose é a indução de craqueamento por radiação, trata-se de uma reação autossustentada de decomposição dos hidrocarbonetos (Zaykin, 2013).

Existem dois tipos de craqueamento induzido por radiação, que são o craqueamento térmico, em inglês radiation-thermal-cracking ( $\mathrm{RTC}$ ), atingindo temperaturas que variam de $350^{\circ} \mathrm{C}$ a $420^{\circ} \mathrm{C}$, e craqueamento térmico de baixa temperatura, com temperaturas abaixo de $350^{\circ} \mathrm{C}$.

As principais fases de qualquer reação em cadeia consistem na iniciação, propagação e terminação. Tal processo inclui o inicio da reação por radicais produzidos a partir da dissociação de uma molécula do composto inicial e 
da propagação da cadeia. Esta ultima consiste da dissociação de um radical livre grande em olefina e um radical menor e a reação deste com moléculas de iniciação. O processo de propagação da cadeia resulta na formação de uma molécula produto da reação e um novo radical grande. Em virtude de sua baixa reatividade, este radical não pode interagir com outra molécula de iniciação. Entretanto, pode se dissociar numa molécula de olefina ou menor, e consequentemente, num radical mais reativo que será capaz de propagar a cadeia. As reações de terminação ocorrem quando dois radicais livres reagem com outros gerando produtos que não são radicais livres. (Zaykin, 2013)

\subsubsection{Craqueamento térmico por radiação}

O mecanismo de craqueamento térmico por radiação é similar ao craqueamento térmico, entretanto a diferença essencial esta no fato de que as cadeias transportadoras de radicais não são geradas apenas termicamente, mas também pela interação com a radiação ionizante. As principais condições para que a reação de craqueamento em cadeia ocorra são(Zaykin, 2013):

$\checkmark$ Formação e manutenção de concentrações relativamente baixas de cadeias transportadoras de radicais (como radicais leves de $\mathrm{H}, \mathrm{CH}_{3}$, $\mathrm{C}_{2} \mathrm{H}_{5}{ }^{*}$ ) necessárias para o inicio do craqueamento.

$\checkmark$ Formação e manutenção de concentrações suficientes de moléculas excitadas necessárias para a propagação em cadeia provocada pela interação dos radicais com moléculas excitadas e suas desintegrações.

No primeiro estágio do RTC, as cadeias transportadoras de radicais são criadas por radiação. A energia absorvida dos elétrons para a formação de concentrações de radicais necessárias para iniciar o craqueamento está em torno de $0,4 \mathrm{~kJ} / \mathrm{mol}$. O estágio de propagação do RTC continua sendo termicamente ativado. O mecanismo envolvido na produção de radicais no RTC assume que a iniciação da cadeia induzida por radiação não depende da temperatura, portanto a 
taxa de geração de radicais depende apenas da taxa de dose de radiação (Zaykin, 2013).

Existem cinco reações principais que contribuem consideravelmente para o craqueamento térmico por radiação em hidrocarbonetos:

$\begin{array}{ll}\mathbf{R}+\mathbf{R} \rightarrow \mathbf{H} & \text { Recombinação } \\ \mathbf{R}+\mathbf{R} \rightarrow \mathbf{O L}+\mathbf{R H} & \text { Dismutação } \\ \mathbf{R} \rightarrow \mathbf{R}_{\mathbf{1}}+\mathbf{R H} & \text { Dissociação } \\ \mathbf{R}+\mathbf{R H} \rightarrow \mathbf{R}_{\mathbf{2}}+\mathbf{R H} & \text { Quebra da molécula } \\ \mathbf{R}+\mathbf{O L} \rightarrow & \text { Polimerização }\end{array}$

Onde:

$\mathbf{R}$ é o radical

OL é a olefina

As transformações químicas causadas pela irradiação, à temperatura elevada numa matriz de hidrocarbonetos com alto peso molecular, são complicadas em virtude da redistribuição da energia da radiação entre os componentes originais desta mistura complexa e ao grande número de reações colaterais. Os efeitos mais importantes da radiação com amostras contendo altas concentrações de parafina e de óleo de alta viscosidade são a isomerização e a polimerização nas condições do RTC (Zaykin, 2004, 2013).

A isomerização por radiação ionizante em frações leves do petróleo é importante por duas razões, a primeira deve se à isomerização, ou seja, a formação de alcanos ramificados, é uma forma conveniente para aumentar o número de octanagem da gasolina e a segunda $A$ isomerização aprimorada pela radiação faz uma contribuição importante na formação de estados moleculares instáveis necessários para a propagação da cadeia de reações de craqueamento à baixas temperaturas (Zaykin, 2004, 2013).

A polimerização induzida pela radiação tem um papel de grande importância nas transformações estruturais e conversões químicas de moléculas 
de alto peso molecular. Este fenômeno compete com o craqueamento e limita a concentração de produtos leves no processo de craqueamento térmico em qualquer tipo de óleo com alta viscosidade. Em óleos com quantidades elevadas de parafinas, este efeito influencia na otimização do óleo, ou seja, o RTC torna-se difícil, consequentemente os rendimentos da gasolina e do querosene são afetados. Experimentos mostram que há diminuição da concentração de frações leves, em doses moderadas de irradiação, devido à polimerização(Zaykin, 2008, 2013; Zaykin et al., 2004).

\subsubsection{Aplicação da radiação ionizante na redução do teor de enxofre no petróleo}

Um dos primeiros estudos que visava a dessulfurização do petróleo com a utilização da radiação ionizante foi realizado no final dos anos 50 e demonstrou que o enxofre foi convertido da forma quimicamente estável para uma forma quimicamente instável ou então que houve enfraquecimento das ligações(Zaykin, 2007).

Estudos mais recentes demonstram que a utilização de ozônio juntamente com ar ionizado leva a oxidação de compostos sulfurosos sendo que as sulfonas ou sulfóxidos podem posteriormente ser removidos por métodos de extração ou adsorção (Zaykin, 2007; Zaykina, 2004).

Num outro estudo, os sulfetos do tipo tiofeno foram dissolvidos em ndodecano para simular o petróleo, tendo sido aplicada radiação gama em conjunto com peróxido. Os resultados demonstraram que os compostos em baixa concentração eram degradados de forma mais eficaz do que aqueles que estavam em altas concentrações. Além disso, a degradação do benzotiofeno e do dibenzotiofeno foi mais rápida devido à adição do peróxido durante o processo de radiação. Sendo que a remoção do benzotiofeno e dibenzotiofeno atingiu 32,5\% e $70,4 \%$, respectivamente, por adição do peróxido de hidrogênio em comparação com 7,8\% e 14,6\% sem peróxido de hidrogênio, respectivamente(Zhang, 2009). 


\subsection{Métodos analíticos para análise de petróleo}

Atualmente inúmeras técnicas instrumentais podem ser utilizadas para a determinação de hidrocarbonetos, como por exemplo, a cromatografia a gás, CG, a cromatografia a gás associada à espectrometria de massa, CG-MS, a cromatografia liquida de alta eficiência, CLAE, a espectroscopia do infravermelho, IV, a cromatografia de fluído supercrítico, CFS, a cromatografia de camada delgada, CCD, a espectroscopia de fluorescência e ultravioleta, UV, e a espectrometria de massa por radioisótopos(Wang, 2003).

Para determinar o enxofre total em frações e derivados do petróleo, técnicas como microcoulometria oxidativa, fluorescência UV e fluorescência de raio $\times$ (ASTM D2622) podem ser aplicadas. Na determinação do nitrogênio total em petróleo pode também ser utilizada a microcoulometria oxidativa (ASTM D3431), a quimioluminescência e o método de Kjeldhal(Speight, 2001)

Contudo as técnicas citadas não são capazes de identificar os compostos moleculares onde tais heteroátomos estão presentes, logo, técnicas como a GC-MS e espectrometria de emissão podem ser usadas com esta finalidade.

Além disto, em virtude do petróleo ser uma amostra complexa, são necessários tratamentos anteriores à análise química, com o intuito de melhorar a qualidade do resultado obtido. Um dos procedimentos mais importantes do processo analítico é a preparação ou abertura da amostra(Kenkel, 2003).A preparação da amostra é designada tanto para enriquecer compostos com baixas concentrações quanto para remover compostos indesejados da matriz, evitando, desta forma, que haja sobreposições do analito num processo de análise dos componentes de interesse. Portanto, a escolha do método de separação depende do comportamento físico e químico, da concentração do analito e da matriz do componente(Kenkel, 2003). 


\subsubsection{Extração liquido/liquido}

$\mathrm{Na}$ literatura são descritas técnicas analíticas para compostos orgânicos de enxofre e nitrogênio, incluindo a extração liquido/liquido, que se baseia no balanço do analito em duas fases imiscíveis e é normalmente usada para compostos de enxofre voláteis e semi-voláteis e também para compostos de nitrogênio. Esta técnica apresenta uma boa recuperação e reprodutibilidade, especialmente com compostos não polares e neutros.

Alguns autores caracterizam a extração liquido-liquido como associada a um processo oxidativo, utilizando como agente oxidante o peróxido de hidrogênio e a extração utilizando líquidos iônicos como solvente para extração de compostos sulfurados e nitrogenados em amostras de petróleo. (Lissner, 2012; Oliveira, 2004).

\subsubsection{Extração em fase sólida}

A extração em fase sólida, SFE, ou cromatografia clássica foi desenvolvida como opção à extração liquido/liquido devido as vantagens que esta apresenta, tais como a redução do tempo de análise e a redução do consumo de solventes(Lanças, 2009; Oliveira, 2004).

O SFE baseia-se no mecanismo de separação da cromatografia liquida de baixa pressão, empregando uma pequena coluna aberta, que contem a fase estacionária apropriada. Uma solução contendo o analito é então colocada no topo da coluna já empacotada. Os analitos serão adsorvidos na fase estacionária, seletivamente, ao adicionar a fase móvel estes se deslocam de acordo com sua afinidade com a coluna, isto permite que a separação de compostos ocorra(Lanças, 2009; Oliveira, 2004).

Inúmeros estudos utilizam a sílica e/ou alumina como fase estacionaria para o fracionamento de combustíveis fosseis. No caso dos hidrocarbonetos, as pesquisas que envolvem SFE foram desenvolvidas de acordo com o que se desejava analisar. Alguns autores utilizaram sílica para fracionar o combustível 
liquido em oito frações, sendo cinco apolares, (saturados, monoaromáticos, diaromáticos,triaromáticos, polinucleares), uma polinuclear aromática ,uma de polaridade intermediaria (resina) e duas frações polares (asfaltenos e asfaltois)(Oliveira, 2004; Speight, 2006).

Atualmente o método SARA (saturados, aromáticos, resinas e asfaltenos) e PONA (parafinas, isoparafinas, oleofinas, naftenos e aromáticos) são amplamente utilizados como pré-tratamento na análise de hidrocarbonetos(Fan, 2002; Oliveira, 2004; Panda, 2007; Speight, 2006).

$\mathrm{Na}$ análise de compostos de enxofre em óleo cru e derivados do petróleo, alguns autores utilizaram como pré tratamento da amostra o SFE ou a combinação deste método com outros.

Algumas pesquisas apontam para a utilização de nitrato de prata como tratamento inicial, para remover compostos sulfurados reativos como tióis e sulfetos. Em seguida utilização de SFE, cuja fase estacionaria utilizada foi Wakigel e a partir da utilização de diferentes solventes conseguiu se obter frações aromáticas sulfuradas(Miki, 2007, 2008).

Diversos autores utilizaram coluna de troca iônica sílica gel com cloreto de paládio como fase estacionaria para separar compostos heterociclossulfurados aromáticos (polycyclicaromaticsulfurheterocycles - PASH) de hidrocarbonetos aromáticos policíclicos (polycyclicaromatichydrocarbons - PAH). Nestes experimentos o cloreto de paládio foi empregado porque os sulfetos orgânicos formam complexos com metais pesados, logo, esta característica foi aplicada para separar PASH de compostos que não formam complexo(Machado et al., 2011, 2013; Nishioka, 1988; Xiaolan et al., 2006).

$\mathrm{Na}$ separação de compostos de nitrogênio em petróleo, alguns pesquisadores utilizaram coluna sílica ácida, obtiveram três frações, que são a nitrogenada pirrolitica, a fração de aminas e a fração nitrogenada básica. Outros pesquisadores utilizaram a combinação de sílica/alumina amorfa, alumina, zeolita e $\mathrm{NH}_{4}$ e obtiveram compostos aromáticos contendo quilonas. Por fim alguns 
pesquisadores recomendam o uso da fase estacionaria clássica como método para separar moléculas contendo heteroátomos de destilados leves de carvão e óleo hidratado, seguida de extração aquosa para separar os compostos nitrogenados em classes(Cheng, 2004; Li, 1999; Oliveira, 2004;Murti, 2002; Wu, 2000).

\subsubsection{Cromatografia gasosa acoplada ao espectrômetro de massa}

Cromatografia é um método físico de separação no qual os componentes a ser separados são distribuídos em duas fases, uma delas é a estacionaria e a outra é móvel, esta segue uma direção definida. $\mathrm{Na}$ cromatografia gasosa a fase móvel é geralmente um gás nitrogênio ou hélio que flui próximo a pressão atmosférica e com uma taxa que varia de 0,5 a $3,0 \mathrm{~mL} / \mathrm{min}$. $O$ analito é injetado na coluna e o gás de arraste transporta-o até a coluna, esse movimento é inibido pela adsorção das moléculas do analito na parede da coluna ou pelo material que a envolve. Os componentes da mistura separam-se e são eluídos um após o outro, direcionando-se para a outra extremidade da coluna. $O$ tempo de retenção do analito na coluna dependerá da força de adsorção e da temperatura. Cada pico eluído da coluna cromatográfica é bombardeado com um feixe ionizante que fraciona o composto em diversos íons, estes são separados no quadrupolo de acordo com a relação massa/carga $(\mathrm{m} / \mathrm{z})$ e por fim detectados.(Herbert, 2003; Machado, 2011).

Diversos autores utilizam do GC-MS para identificar compostos orgânicos em combustíveis fosseis, seja com intuito de revelar a distribuição de hidrocarbonetos saturados e aromáticos no rafinato e nas frações extraídas, ou identificar compostos orgânicos sulfurados (Later et al. 1981; Pasadakis, 2011). Alguns trabalhos utilizam o GC-MS com detector de emissão atômica para determinação de PASH e identificação de compostos orgânicos sulfurados presentes no óleo leve proveniente do ciclo de craqueamento (Depauw, 1997; Xiaolan, 2006). 
Caracterizações feitas no petróleo árabe por GC-MS ajudou na identificação de inúmeros compostos aromáticos e policíclicos aromáticos que contêm nitrogênio.(Qian, 2002). Utilizando GC-MS com ionização química foi possível fazer a caracterização espectral de massas de compostos contendo nitrogênio em amostras de carvão. (Oliveira, 2004).

\subsubsection{Espectroscopia Infravermelho com Transformada de Fourier, FTIR}

A FTIR é uma valiosa ferramenta na identificação de grupos funcionais na estrutura orgânica. $O$ IR baseia-se na absorção de frequências especificas da luz pela molécula, o comprimento de onda absorvido dependera da estrutura. A radiação no infravermelho atravessa a amostra a ser analisada e a radiação transmitida é comparada com aquela que foi transmitida na ausência da amostra. O espectro registra o resultado na forma de bandas de absorção. Com a utilização do FTIR diversos grupos funcionais podem ser identificados. Este método é particularmente importante na análise de constituintes sólidos do petróleo com alto peso molecular, como a fração dos asfaltenos (Speight, 2001).

\subsubsection{Espectrometria de Fluorescência de Raios-X}

A espectrometria de fluorescência de raios-X é uma técnica que permite a análise de inúmeros elementos, ou seja, do berílio ao urânio. Os limites de detecção no nível de ppm, sem pré- concentração e os limites de precisão e exatidão determinam a sua ampla aplicação (Hof, 2003; Potts, 2003).

O método baseia-se na excitação fotoelétrica dos átomos e subsequente desexcitação com emissão de raios-X característico de cada elemento, como resultado tem-se uma linha espectral cuja intensidade é proporcional ao numero de átomos atribuído a esta linha.(Hof, 2003; Potts 2003). 


\subsection{Objetivo}

O objetivo deste trabalho é o estudo da interação da radiação ionizante, proveniente de uma fonte de $\mathrm{Co}^{60}$, em hidrocarbonetos, compostos de enxofre e nitrogênio presentes no diesel e petróleo brasileiros, além de avaliar a eficiência da degradação dos mesmos com diferentes doses absorvidas. 


\section{MATERIAIS E MÉTODOS}

$\mathrm{Na}$ primeira etapa do presente trabalho realizou-se estudos com padrão puro de um composto sulfurados, benzotiofeno, tendo sido este diluído em água. Na segunda etapa foram estudadas amostras reais de diesel e de petróleo brasileiros.

\subsection{Amostras}

O reagente comercial utilizado neste estudo foi o benzotiofeno, BT, da Merck Inc. Preparou-se uma solução padrão com 1391,6 mg.L ${ }^{-1}$ em metanol. A partir desta, preparou-se $50 \mathrm{~mL}$ de solução de trabalho diluída em água destilada para obtenção da curva de calibração e para irradiação.

As amostras de petróleo bruto e de diesel utilizadas nos experimentos foram mantidas sob refrigeração em frasco de vidro âmbar.

Posteriormente, as amostras de benzotiofeno, petróleo e diesel, foram armazenadas em frascos de vidro com capacidade de $20 \mathrm{~mL}$, para o processamento por irradiação a temperatura ambiente.

\subsection{Processamento por radiação ionizante}

A irradiação foi realizada em temperatura ambiente utilizando-se um irradiador gama de Cobalto-60, do tipo Gammacell, modelo 220N, instalado no Centro de Tecnologia das Radiações (CTR), IPEN - CNEN/SP, a taxa de dose foi de $1,45 \mathrm{kGy} / \mathrm{h}$.

Todas as irradiações foram realizadas em sistema de bateladas e as doses administradas foram 1 kGy , 2 kGy , 3 kGy , 4 kGy , 5 kGy, 10 kGy , 15 kGy e 20 kGy para as amostras de benzotiofeno. As amostras de petróleo e de diesel foram irradiadas com as doses de 15 kGy, 30 kGy, 50 kGy, 100 kGy e 150 kGy. $O$ Grupo de Pesquisa em Dosimetria calibra o sistema rotineiramente com dosímetro Fricke para determinar a taxa de dose absorvida. 


\subsection{Análises químicas}

Para análise de compostos orgânicos presentes no petróleo e no diesel foi necessário o estudo e avaliação de várias metodologias analíticas, tanto de separação química, como de instrumentação analítica. Nesse item serão descritas aquelas que apresentaram os melhores resultados, tanto para separação química, como para sensibilidade. Os experimentos foram realizados seis vezes para a curva de calibração do benzotiofeno e análise da degradação do mesmo com diferentes doses de irradiação amostras irradiadas em diferentes datas e para as amostras de petróleo e diesel. Foram utilizadas metodologias diferentes para o benzotiofeno puro, para o diesel e para o petróleo.

\subsubsection{Benzotiofeno, BT}

A concentração de BT nas amostras foi determinada utilizando-se o concentrador de amostras do tipo "Purge and Trap" da OI Analytica, modelo 4560, acoplado ao cromatógrafo a gás associado ao espectrômetro de massa modelo GC-MS-QP5000 da Shimadzu, localizado no laboratório do CTR, apresentado na Figura 4. As amostras foram injetadas numa coluna capilar de sílica fundida (30 m x $0.25 \mathrm{~mm}$ diâmetro interno de $0.25 \mu \mathrm{m}$ ) preenchida com DB5. $O$ gás de arraste utilizado foi o Hélio, com velocidade constante de $42 \mathrm{~cm} / \mathrm{s}$. A programação de temperatura do forno iniciou em $40^{\circ} \mathrm{C}$, na qual permaneceu durante 1 minuto, em seguida foi elevada até $100^{\circ} \mathrm{C} \mathrm{com}$ taxa de aquecimento de $10^{\circ} \mathrm{C} / \mathrm{min}$. e até 300 oC com taxa de aquecimento de $15^{\circ} \mathrm{C} / \mathrm{min}$. As temperaturas do injetor e interface de $250^{\circ} \mathrm{C}$ e $230^{\circ} \mathrm{C}$, respectivamente. 


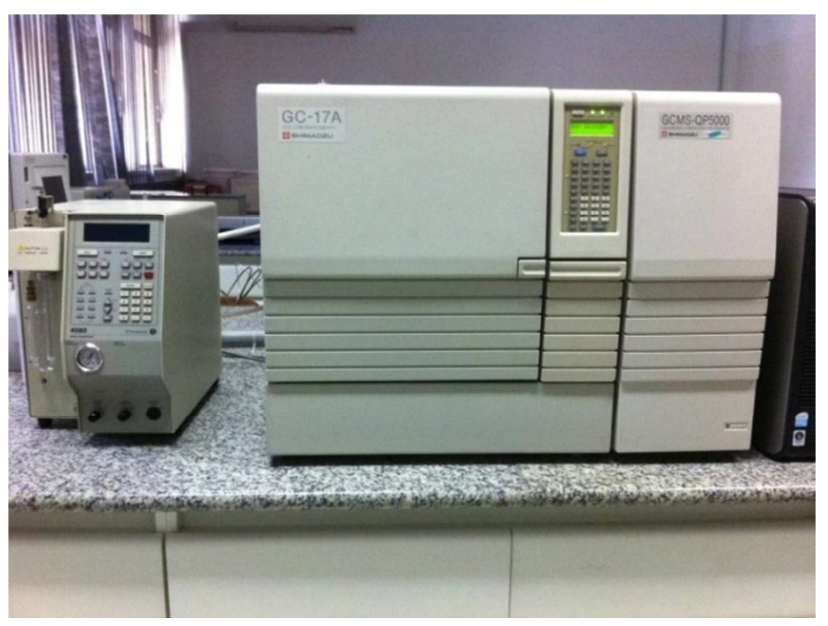

Figura 4. Cromatógrafo a gás associado ao espectrômetro de massa acoplado com um concentrador de amostras do tipo "purge and trap".

\subsubsection{Petróleo e diesel}

A concentração de enxofre total nas amostras de petróleo e diesel foram obtidas em colaboração da Dra. Ivone Mulako Sato do Laboratório de Fluorescendia de Raio-X, do Centro de Química e Meio Ambiente ( CQMA), IPENCNEN/SP. A técnica utilizada foi a Fluorescência de Raios-X por energia dispersiva, utilizando-se o espectrômetro Rany720, da Shimadzu, apresentado na Figura 5. As amostras foram preparadas por deposição de $25 \mathrm{~mL}$ de diesel/petróleo em filtro de papel Whatman n. 42 , com a faixa de trabalho entre $334-10,000 \mathrm{mg} \cdot \mathrm{I}^{-1}$.

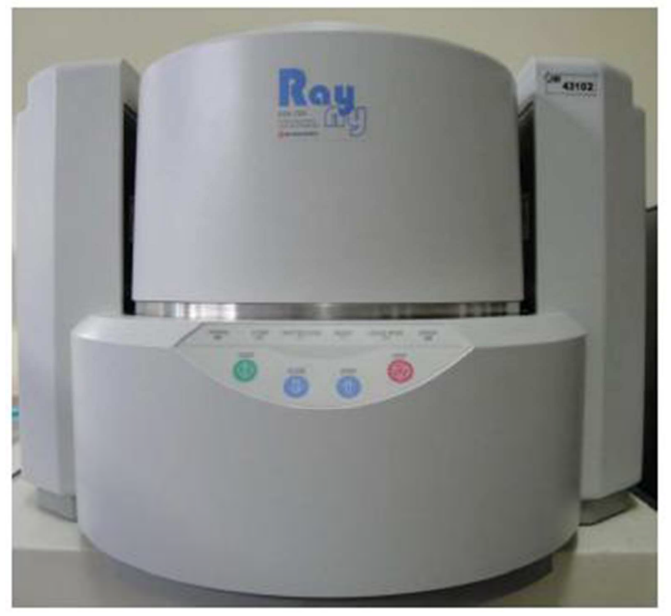

Figura 5. Espectrômetro de Fluorescência de Raios-X por energia dispersiva. 
Para as análises de espectroscopia de infravermelho foi utilizado o FTIR, localizado laboratório do CTR, modelo Espectro 400, da Perkin Elmer, com o acessório de refletância total atenuada, ATR, na faixa de comprimento de onda de 4000 a 650 nm, apresentado na Figura 6.

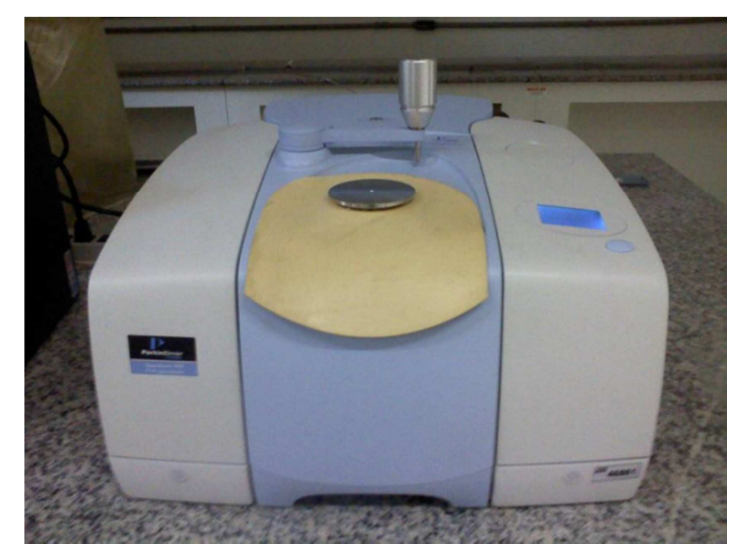

Figura 6. Espectroscopia de infravermelho com acessório de refletância total atenuada.

\subsubsection{Separação química dos compostos sulfurados no diesel}

A separação dos compostos de enxofre presentes no diesel, foram realizados no Laboratórios de Pesquisa de Poluentes Orgânicos (LAPPO), do CTR, IPEN - CNEN/SP, para tanto utilizou-se uma adaptação de método desenvolvido por Later, 1981. As amostras foram pré-fracionadas numa coluna cromatográfica de vidro, aberta, com diâmetro interno de $10 \mathrm{~mm}$ e $20 \mathrm{~cm}$ de comprimento, empacotada com 1,5 g de carvão ativado da marca Fmaia e préumedecida com hexano. Uma alíquota de $0,5 \mathrm{ml}$ de diesel foi dissolvido com $5,0 \mathrm{~mL}$ de hexano e, em seguida, eluída na coluna. A primeira fração, que corresponde majoritariamente aos hidrocarbonetos alifáticos, foi eluída com $20 \mathrm{ml}$ de hexano e a segunda fração, que corresponde aos compostos aromáticos, foi eluída com $50 \mathrm{ml}$ de benzeno. As frações foram recolhidas a cada $10 \mathrm{ml}$. Na Figura 7 apresenta-se um esquema desta separação. 


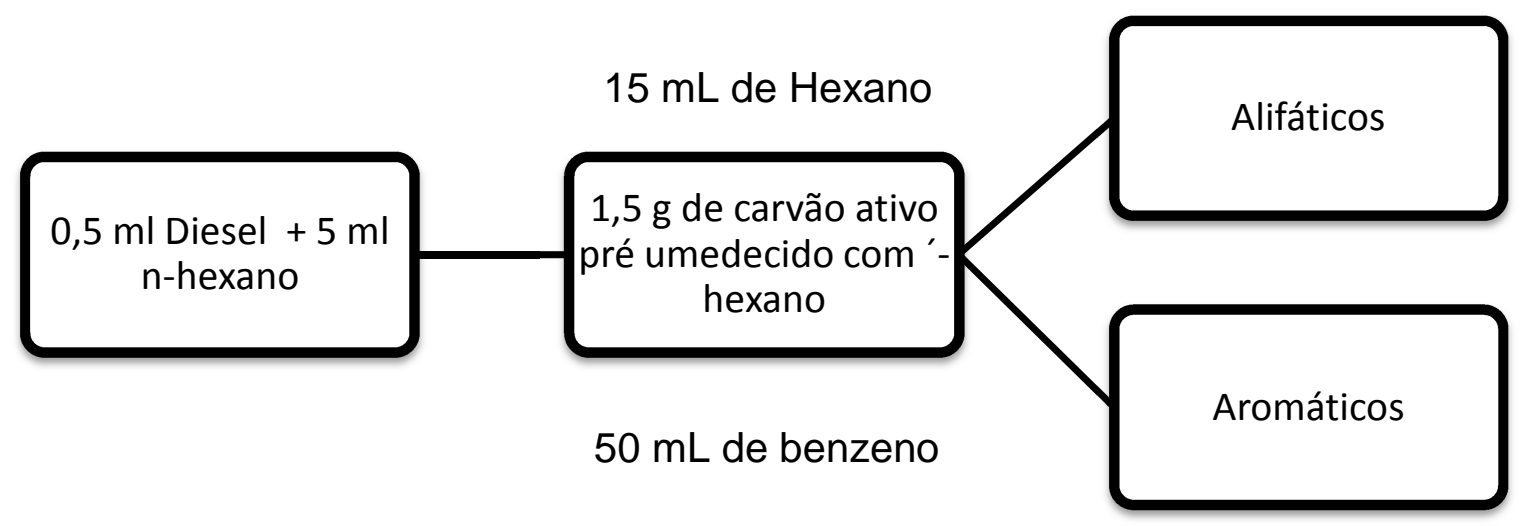

Figura 7. Separação química do diesel em coluna cromatográfica aberta.

\subsubsection{Separação química dos compostos sulfurados do petróleo}

Em virtude da complexidade da composição do petróleo foi necessário fazer uma pré-separação por destilação na primeira etapa e na segunda etapa uma separação em coluna para então ser submetido à análise cromatográfica, ambos procedimentos foram realizados no LAPPO do CTR, IPEN- CNEN/SP.

\subsubsection{Destilação do petróleo}

As amostras de petróleo foram destiladas seguindo o método ASTM1160, para tanto foi necessário o aparato apresentado na Figura 8. A amostra de petróleo foi pesada diretamente no balão de destilação. Primeiramente o sistema foi submetido ao vácuo por 5 minutos e depois iniciou-se o aquecimento até $400^{\circ} \mathrm{C}$. Às temperaturas no balão e no topo do sistema fora medidas durante todo o processo que durou cerca de 20 minutos. O destilado foi recolhido sob refrigeração com gelo seco com temperatura de $-43^{\circ} \mathrm{C}$. Ao final do processo foi medido o volume do destilado. 


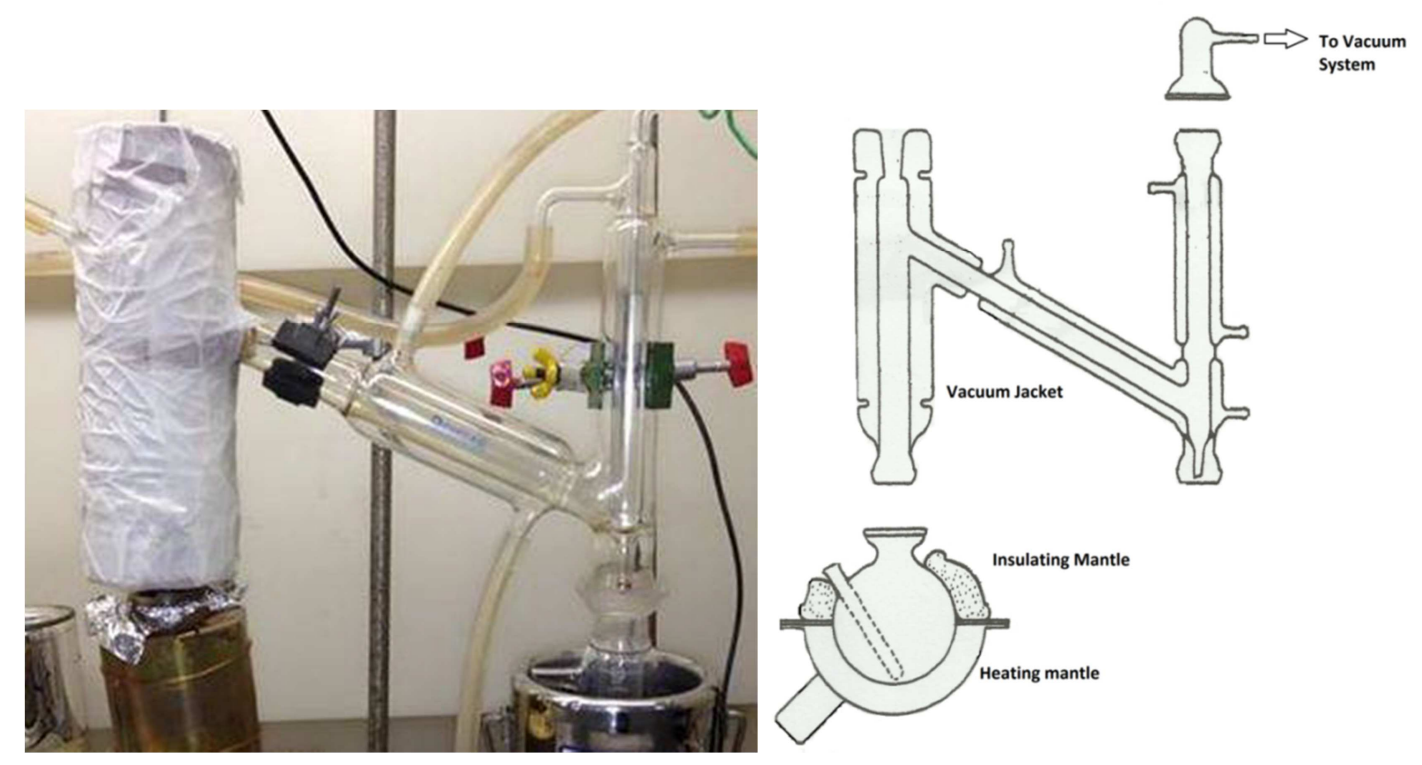

Figura 8. Destilador de baixa pressão de acordo com ASTM 1160.

\subsubsection{Separação dos compostos sulfurados do destilado de petróleo}

A separação dos compostos sulfurados presentes no destilado de petróleo foi baseada nos métodos desenvolvidos por Nishioka e colaboradores em 1987, utilizando-se cloreto de paládio sorvido fisicamente na superfície da sílica gel (Pd-II-SG). Para preparação desse composto, utilizou-se $100 \mathrm{~mL}$ de uma solução $0,01 \mathrm{~g} \mathrm{~L}^{-1}$ de $\mathrm{PdCl}_{2}$ em água deionizada, com agitação magnética por 30 min., em seguida, esta solução foi misturada a $20 \mathrm{~g}$ de SG, sendo a fase liquida separada da sólida por decantação e o material sólido obtido foi seco em estufa a $90 \stackrel{\circ}{\circ}$ por $12 \mathrm{~h}$ e em seguida aquecido a $200 \stackrel{\circ}{\circ}$ por um período de $24 \mathrm{~h}$.

Uma coluna cromatográfica aberta foi empacotada com $5 \mathrm{~g}$ de Pd-II$\mathrm{SG}$, pré-umedecido com $\mathrm{n}$-hexano/clorofórmio, uma fração de $0,5 \mu \mathrm{L}$ do petróleo destilado foi dissolvida em uma mistura de $\mathrm{n}$-hexano/clorofórmio na proporção de 1:1 e eluído nessa coluna. Na Figura 9 é apresentado o esquema de separação utilizado. As frações foram recolhidas em tubos de vidros de $10 \mathrm{ml}$. 


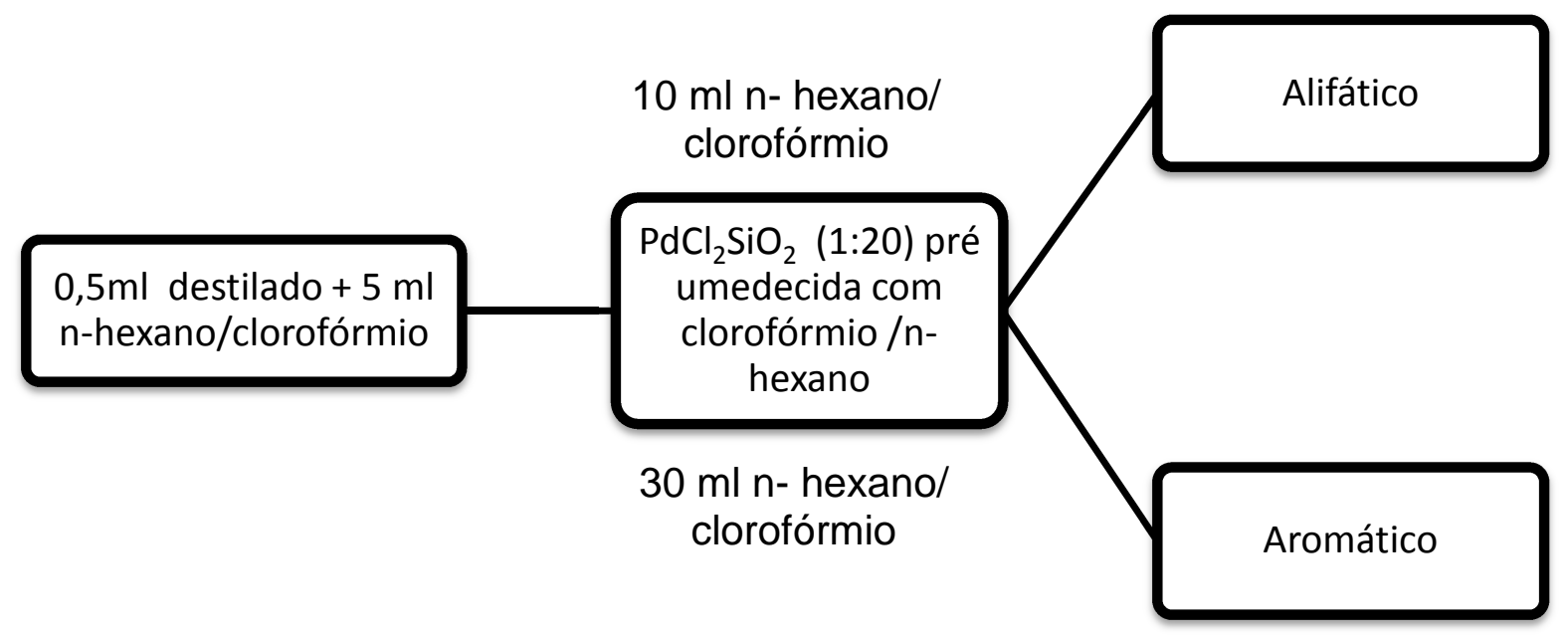

Figura 9. Separação do destilado de petróleo por cromatografia de coluna aberta empacotada com $\mathrm{PdCl}_{2} \mathrm{SiO}_{2}$

Em um segundo teste com as amostras de petróleo, apresentado na Figura $10,0,5 \mathrm{~mL}$ do destilado foi dissolvido em $5,0 \mathrm{ml}$ de $\mathrm{n}$-hexano/clorofórmio (1:1) e eluída numa coluna cromatográfica aberta, empacotada com $1,5 \mathrm{~g}$ de carvão ativado pré-umedecido com n-hexano/clorofórmio (1:1). Os compostos foram eluídos com $50 \mathrm{ml}$ de $\mathrm{n}$-hexano/clorofórmio $1: 1$ e as frações foram recolhidas em tubos de vidro de $4 \mathrm{ml}$.

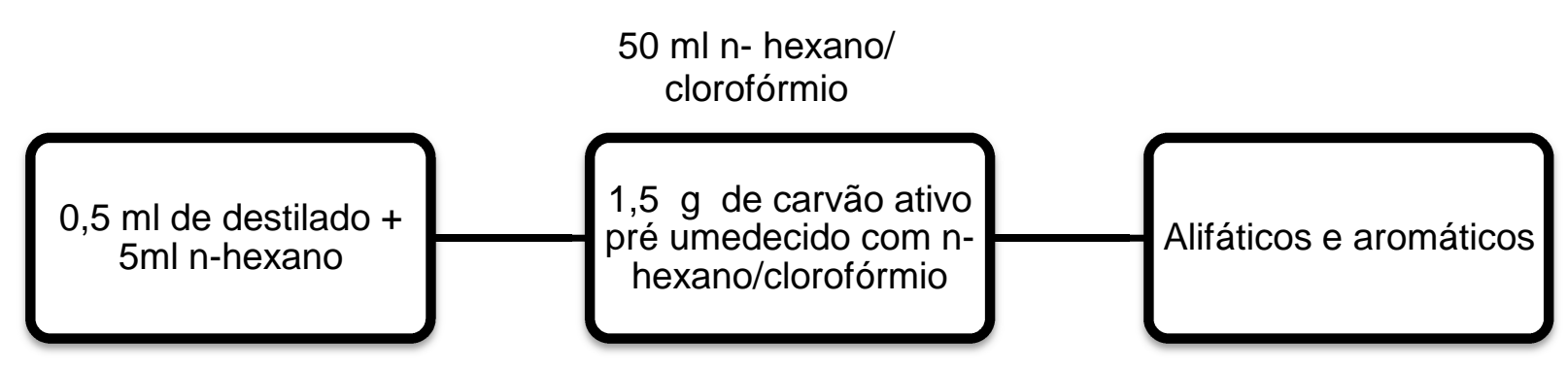

Figura 10. Esquema de separação do destilado de petróleo por cromatografia de coluna aberta empacotada com carvão ativo.

As amostras foram analisadas por cromatografia gasosa acoplada a um espectrômetro de massa, modelo GC-MS QP5000 da Shimadzu, coluna DB5 e hélio como gás de arraste. As temperaturas do injetor e da interface foram mantidas a $280^{\circ} \mathrm{C}$, a programação de temperatura do forno iniciou-se com $40{ }^{\circ} \mathrm{C}$, 
mantendo-se por 1 minuto e a rampa de aquecimento foi de $4{ }^{\circ} \mathrm{C} / \mathrm{min}$ até $280{ }^{\circ} \mathrm{C}$, onde se manteve por 5 minutos. O espectrômetro de massa operou no modo de impacto de elétrons a $70 \mathrm{eV}$. 


\section{RESULTADOS E DISCUSSÃO}

Para facilitar a compreensão dos estudos realizados, os resultados e discussões serão apresentados em tópicos que avaliam os efeitos da radiação ionizante na molécula modelo, no diesel e por fim no petróleo.

\subsection{Benzotiofeno}

O espectro do BT obtido no concentrador do tipo "purge and trap" associado ao GC-MS é apresentado na Figura 11, pode-se observar que apresentou boa qualidade e pico bem definido.

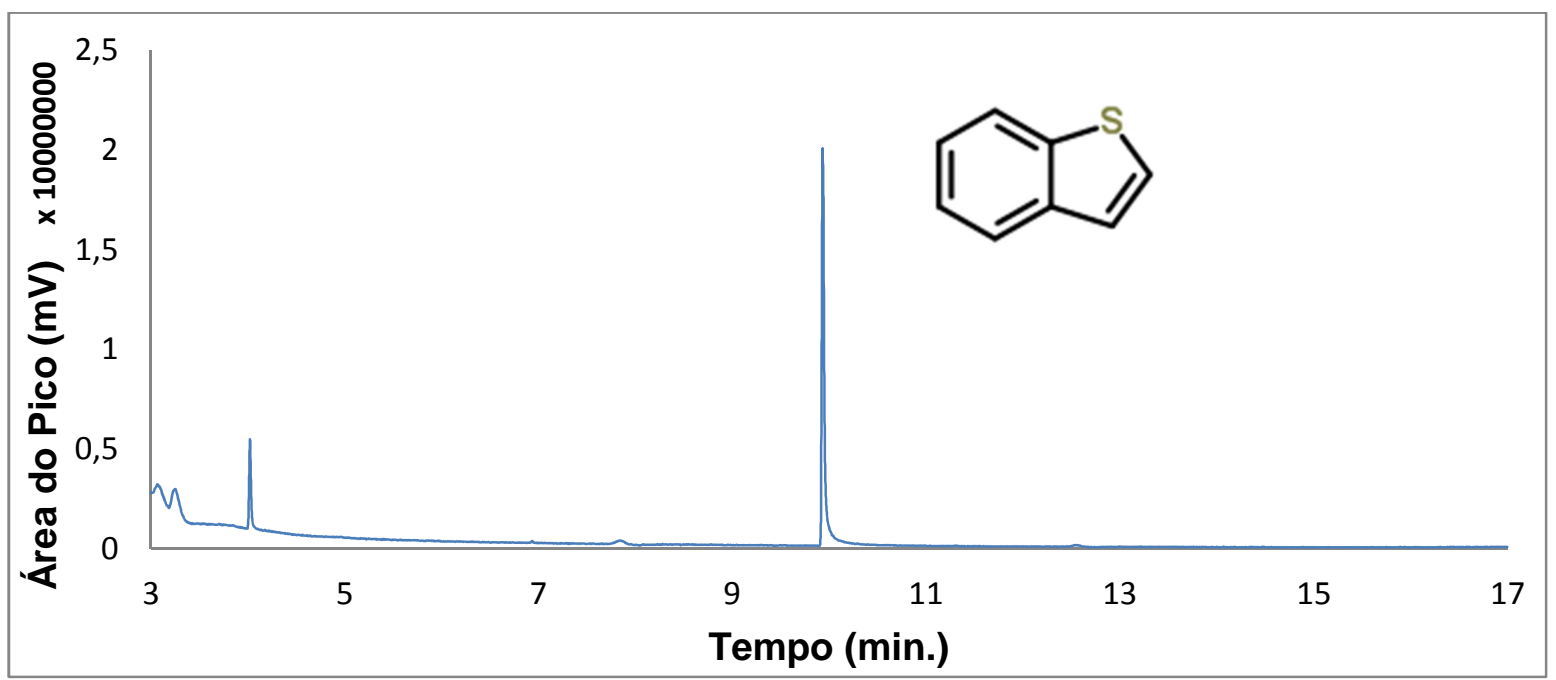

Figura 11. Cromatograma do benzotiofeno obtido no GC-MS associado ao concentrador de amostras do tipo "purge and trap".

A curva de calibração foi obtida a partir da diluição do BT em água e apresentou um coeficiente de regressão de 0,9882 e a variabilidade experimental obtida ( $\mathrm{N}=10$ ), expressa com desvio padrão foi de $10 \%$. O limite de quantificação (LQ) obtido foi de 3,17 $\mu \mathrm{g} / \mathrm{L}$ e o limite de detecção (LD) foi de 1,05 $\mu \mathrm{g} / \mathrm{L}$. Na Figura 12 é apresentada a curva obtida. 


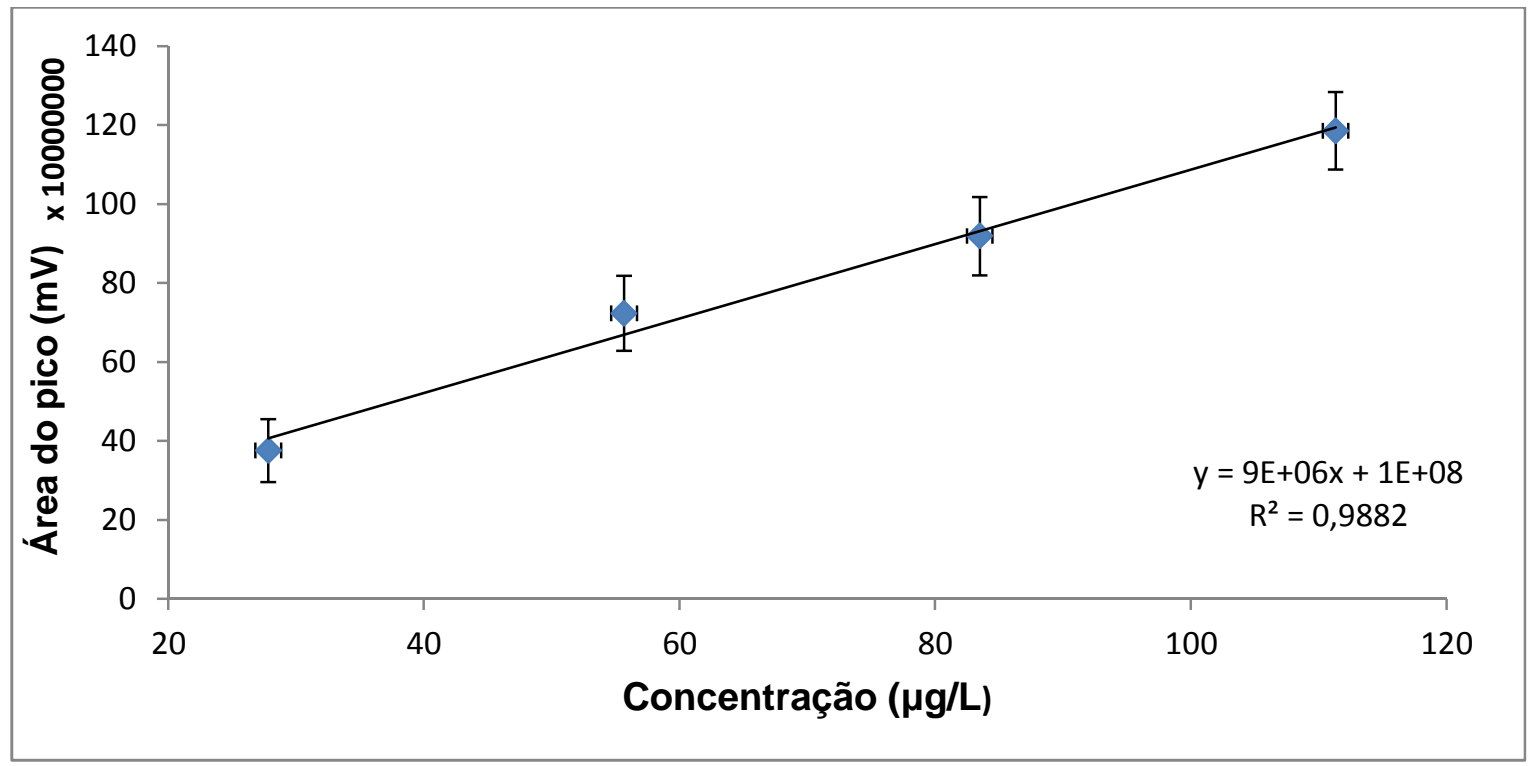

Figura 12. Curva de calibração do BT obtida no GC-MS após pré-concentração em sistema Purge and Trap.

Imediatamente após o processo de irradiação, as amostras foram analisadas para de quantificar a remoção do BT(\%) em função da dose absorvida, como pode se observar na Figura 13. A eficácia deste processo de oxidação está relacionada com o aumento da dose de radiação.

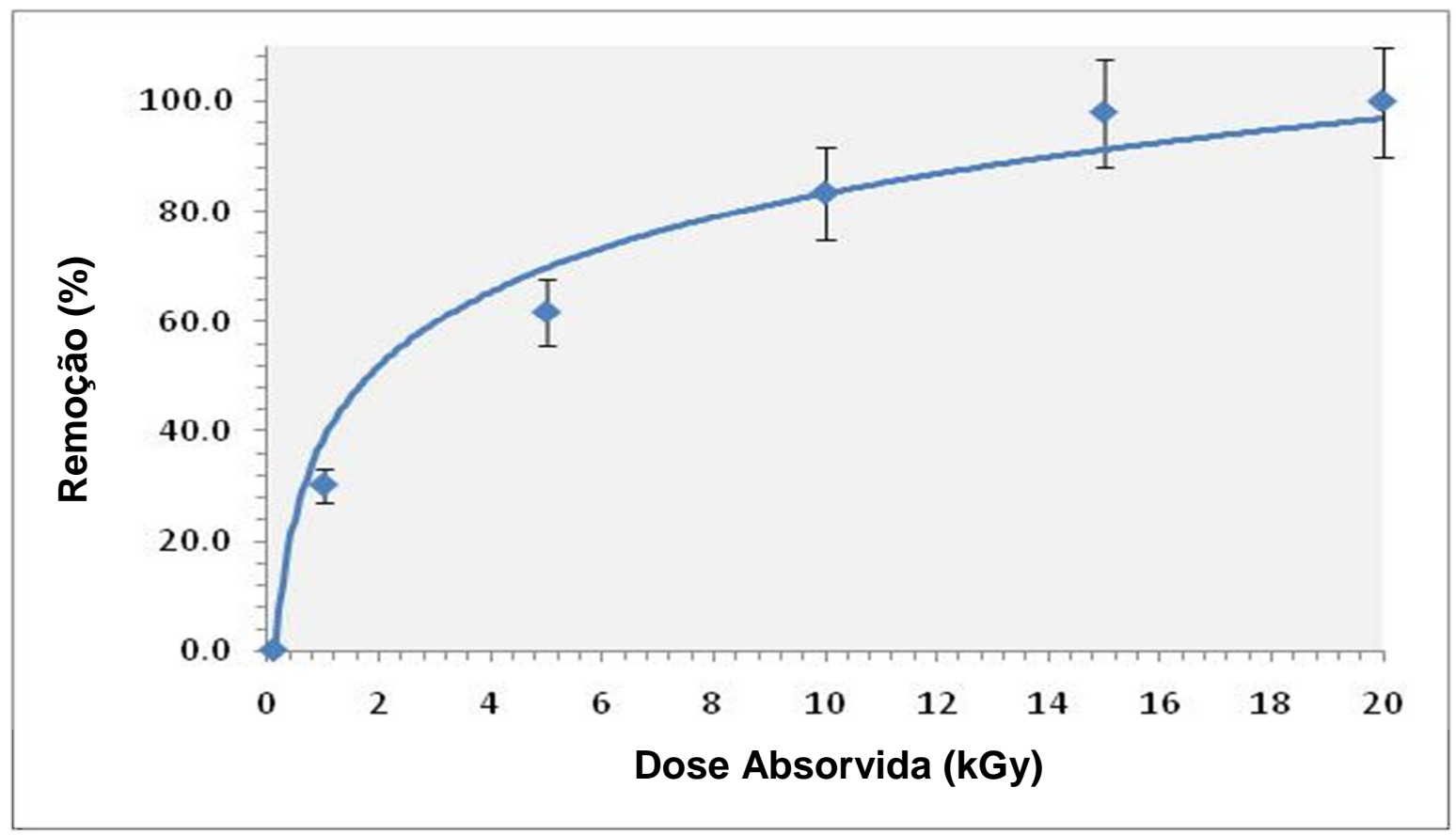

Figura 13. Remoção do benzotiofeno em função da dose absorvida de radiação 
Os resultados mostram, com nível de confiança de 95\% e reprodutibilidade, que 95,98\% totalidade da BT foi degradado com $20 \mathrm{kGy}$, com as doses de 10 e 15 kGy a degradação foi de $81,47 \%$ e $86,77 \%$ respectivamente.

Nesta fase, observou-se que a presença de água afeta diretamente a eficiência do processo de irradiação, sabe-se que a água sofre decomposição em radicais oxidantes como a hidroxila e redutores como o átomos de hidrogênio. Para avaliar se a degradação se deu principalmente pela reação com os radicais hidroxila, foi realizado um estudo de bloqueio desses radicais com a adição de metanol. O metanol reage com os radicais hidroxilas oxidando-os e revertendo o efeito da radiação (Eq. 1 e 2). Para tanto diluiu-se benzotiofeno em água com a adição de $20 \%$, 40\% e 60\% de metanol e as amostras foram irradiadas com 5 kGy, 10 kGy, 15 kGy e 20 kGy. Os resultados da remoção do BT em função da dose absorvida podem ser observados no gráfico da Figura 14.

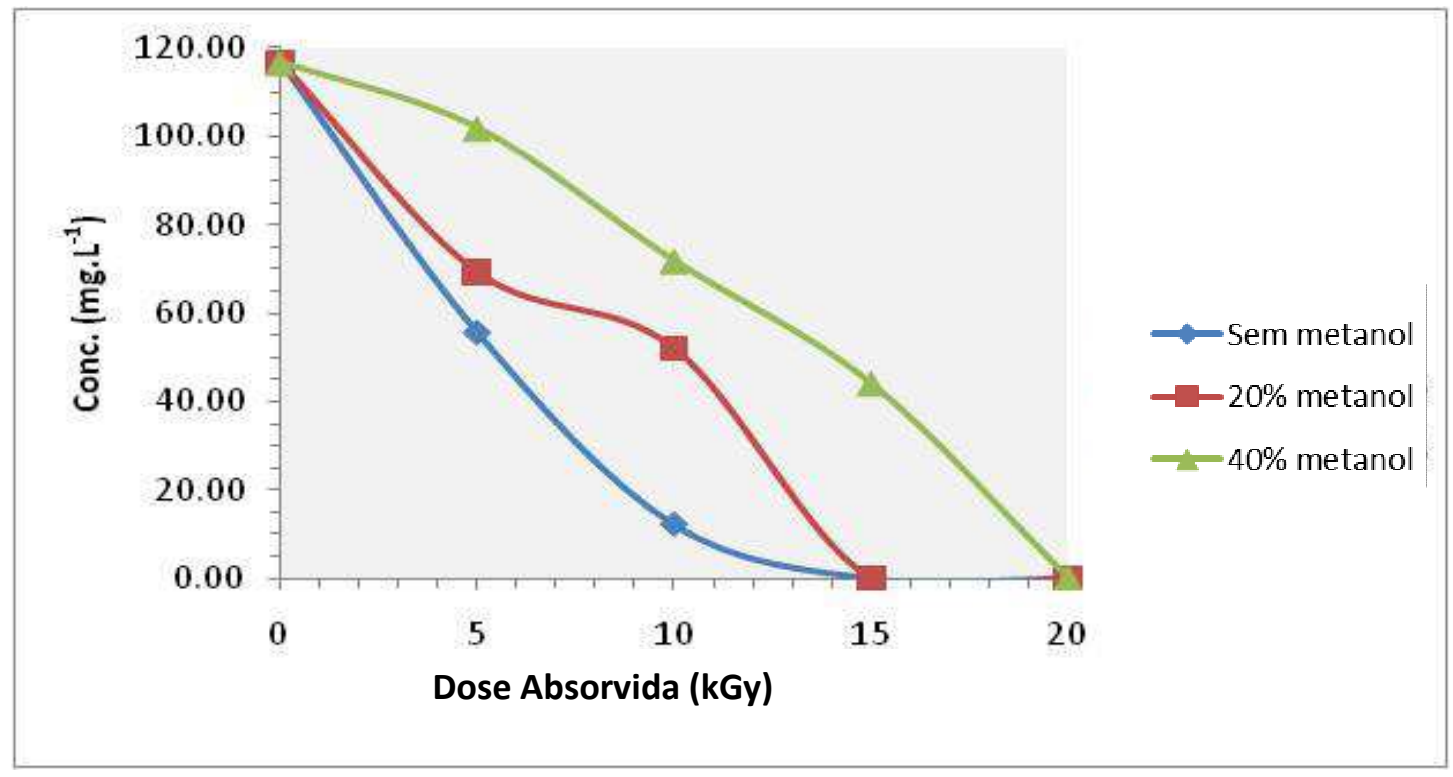

Figura 14. Concentração do BT em metanol em função da dose absorvida.

Como pode ser visualizado pelo gráfico da Figura 14, a presença de metanol interferiu na degradação do benzotiofeno pela radiação, comparando a dose de 20 kGy em todas as amostras com diferentes concentrações de metanol, nota-se que com $20 \%$ de metanol a degradação foi de aproximadamente $86 \%$ e com a adição de $60 \%$ de metanol não ocorre a degradação e sim o aumento da 
concentração do benzotiofeno . Dessa forma infere-se que o principal radical responsável pela degração do BT é a hidroxila e o possível mecanismo para oxidação do BT é proposto na eq. (3), ainda segundo a literatura o BT sofre oxidação para sulfóxido e sulfona.

$$
\begin{aligned}
& \mathrm{H}_{2} \mathrm{O} \rightarrow \mathrm{H}, \cdot \mathrm{OH}, \mathrm{H}_{2}, \mathrm{H}_{2} \mathrm{O}_{2} \\
& \text { metOH }+2 \cdot \mathrm{OH} \rightarrow \mathrm{H}_{2} \mathrm{O}+\mathrm{O}_{2}
\end{aligned}
$$

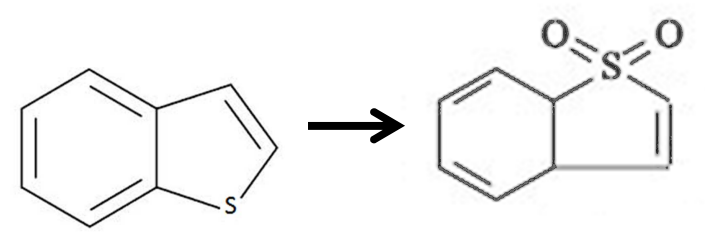

Contudo, a partir da análise no GC-MS das amostras de BT irradiadas, observou-se a formação de fragmentos, apresentados na Figura 15, tais como benzotiofano, tiofeno, tolueno e dimetilbenzeno em proporções baixas se comparadas com a concentração do BT.<smiles>c1ccc2c(c1)CCS2</smiles>

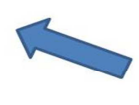<smiles>Cc1ccccc1</smiles><smiles>c1ccc2sccc2c1</smiles><smiles>C=C=Cc1cccs1</smiles><smiles>C=C[14c]1ccc(C)c(C)c1</smiles>

Figura 15. Compostos formados pela degradação de BT pela radiação ionizante.

Os grupos sulfóxidos e sulfona, que segundo a literatura são formados durante o processo de irradiação, não foram identificados por GC-MS.

\subsection{Avaliação do efeito da radiação ionizante no Diesel}

A avaliação do efeito da radiação nas amostras de diesel foram realizadas dez dias após o processamento por radiação, para estas serão 
considerados os resultados obtidos nas análises de concentração de enxofre total por fluorescência de raios-x e nos resultados obtidos por GC-MS de hidrocarbonetos e de compostos orgânicos sulfurados e nitrogenados

\subsubsection{Enxofre molecular total}

Para a curva de calibração de fluorescência de Raios-x utilizou-se como padrão o benzotiofeno, com intervalo de concentração de 334-10,000 mg.L' ${ }^{1}$ como parâmetro de comparação das amostras, sendo obtido o coeficiente de regressão de 0,9944 e a variabilidade experimental $(N=3)$, foi de $15 \%$ de desvio padrão.

Na Tabela 5 são apresentados os resultados de enxofre molecular total nas amostras de diesel não irradiadas e irradiadas com doses de 30 e 50 kGy. Não houve variação na concentração de enxofre no diesel, o que demonstra que, embora possa ter havido alteração na forma química, o enxofre molecular continuava presente nas amostras, ou seja não foi liberado o $\mathrm{H}_{2} \mathrm{~S}$ que é a forma volátil do enxofre.

Tabela 5. Concentração de enxofre molecular total na amostra de diesel não irradiada e após a irradiação.

\begin{tabular}{cc}
\hline $\begin{array}{c}\text { Dose Absorvida } \\
\text { (kGy) }\end{array}$ & $\begin{array}{c}\text { Concentração de enxofre } \\
\text { mg. } \mathbf{L}^{-1}\end{array}$ \\
\hline Não irradiada & $3028 \pm 58$ \\
$\mathbf{1 5}$ & $3765 \pm 54$ \\
$\mathbf{3 0}$ & $2847 \pm 28$ \\
$\mathbf{5 0}$ & $3940 \pm 47$ \\
\hline
\end{tabular}




\subsubsection{Efeito da radiação nos compostos orgânicos do Diesel}

Nas amostras de diesel foram analisados, separadamente, os hidrocarbonetos, os compostos orgânicos nitrogenados e os compostos orgânicos sulfurados, que foram identificados com as siglas DH, DN e DS, respectivamente.

\subsubsection{Hidrocarbonetos}

Os compostos orgânicos presentes no diesel, foram previamente separados por cromatografia de coluna aberta, cuja fase estacionária era carvão ativo e, através da utilização de diferentes solventes, os compostos aromáticos e alifáticos foram separados, entretanto observou-se que alguns compostos alifáticos de alto peso molecular como o tetradecano, o 2 metil heptadecano, o 2 metil octadecano, o nanocosano e o tricontano coeluiram juntamente com a fração aromática, cujos principais foram o xileno, o trimetilbenzeno e o 2 metil naftaleno. Na Tabela 6 são apresentados o nome, a sigla que será usada no presente trabalho e a fórmula estrutural desses hidrocarbonetos.

Para que seja melhor visualizado o efeito da irradiação nesses compostos, foi construído o gráfico apresentado na Figura $16 \mathrm{com}$ a área do pico de cada composto identificado na Tabela 6 em função da doses absorvida de radiação. O composto presente em concentração muito mais elevada que os demais foi o metil naftaleno (HD3), por isso no Figura 17 este composto foi retirado para melhor visualização dos demais compostos. Pode-se observar que a concentração de alguns compostos reduziram com doses de 15 kGy e 30 kGy e outros aumentaram. 
Tabela 6. Compostos orgânicos alifáticos e aromáticos identificados nas amostras de diesel após separação em carvão ativo

Compostos Alifáticos e Aromáticos
Sigla
2-metil naftaleno
2-Xileno
Tetradecano (C14)
2-Metiloctadecano (C19)
Nonacosano (C29)




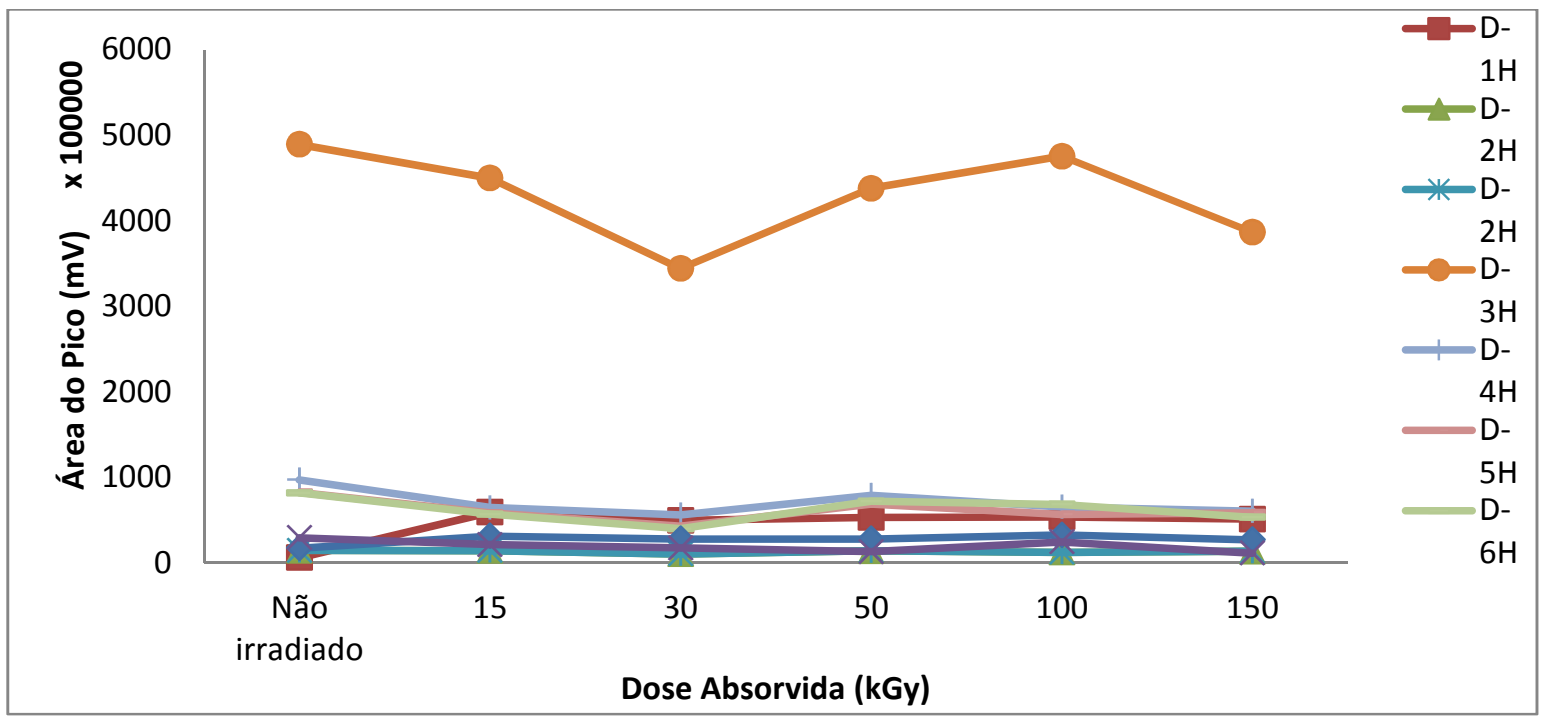

Figura 16. Variação da área do pico dos principais compostos aromáticos e alifáticos no diesel com a dose absorvida de radiação.

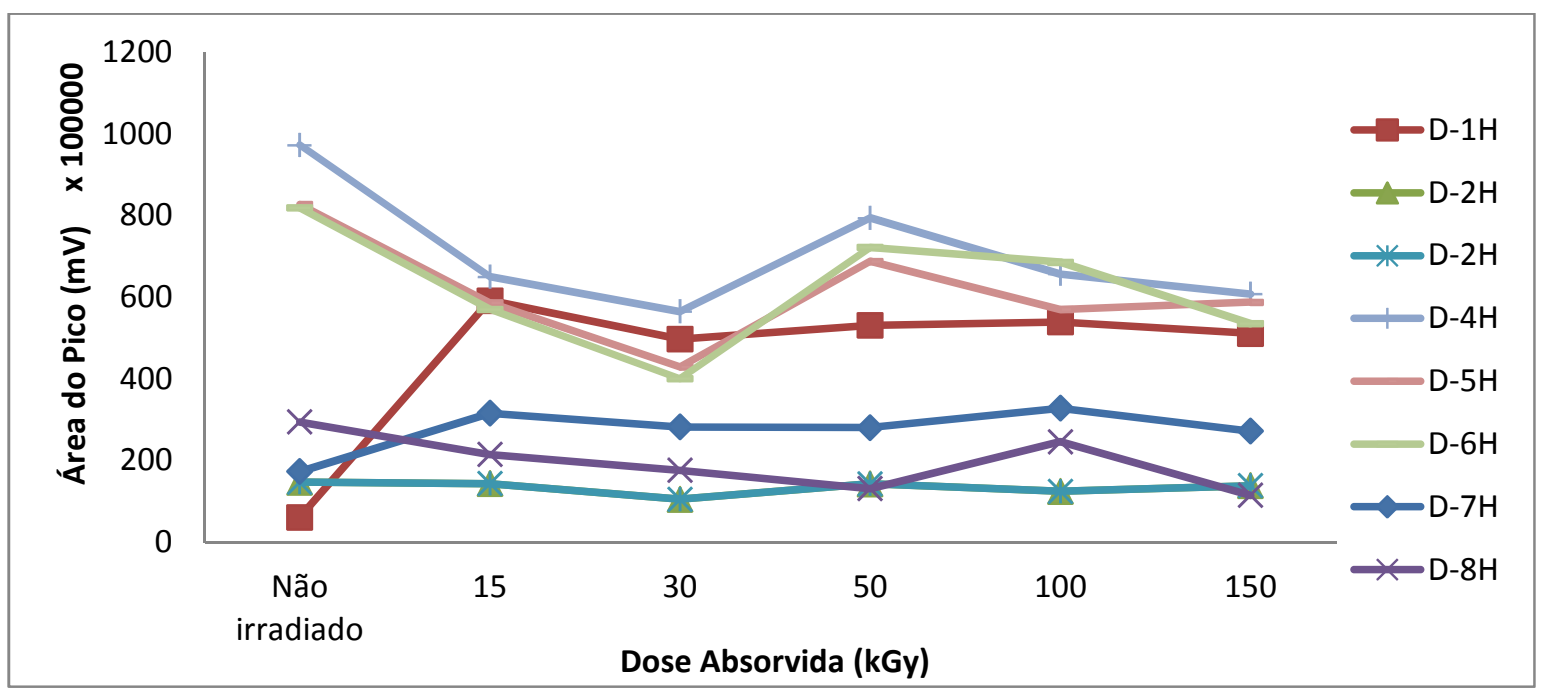

Figura 17. Variação da área do pico dos principais compostos aromáticos e alifáticos no diesel com a dose absorvida de radiação, sem o metilnaftaleno.

As variações nas concentrações foram calculadas em forma de porcentagem e os resultados são apresentados na Tabela 7. Dentre os aromáticos observou-se que o composto Xileno (D1-H) apresentou um aumento na concentração após a irradiação, principalmente com a dose de 15 kGy. O aumento deste composto se deu como resultado das reações de decomposição 
de compostos aromáticos mais complexos como o metil naftaleno que possui dois anéis aromáticos e, principalmente pela perda de um radical metila do trimetilbenzeno. Consequentemente esses compostos apresentaram as maiores porcentagens de remoção com $30 \mathrm{kGy}$, cerca de $30 \%$. Os anéis aromáticos são mais resistentes à radiação, pois sistemas conjugados redistribuem a energia absorvida por toda molécula.

Tabela 7. Degradação e /ou formação de hidrocarbonetos (\%) na amostra de diesel após a irradiação

\begin{tabular}{c|ccccc}
\hline \multirow{2}{*}{ Sigla } & \multicolumn{5}{|c}{ Dose Absorvida (kGy) } \\
& $\mathbf{1 5}$ kGy & $\mathbf{3 0}$ kGy & $\mathbf{5 0}$ kGy & $\mathbf{1 0 0}$ kGy & $\mathbf{1 5 0}$ kGy \\
\hline D-1H & -871 & -716 & -771 & -785 & -739 \\
D-2H & 2 & 29 & 3 & 15 & 6 \\
D-3H & 8 & 30 & 10 & 3 & 21 \\
D-4H & 33 & 42 & 18 & 33 & 38 \\
D-5H & 29 & 48 & 17 & 31 & 29 \\
D-6H & 30 & 51 & 12 & 16 & 35 \\
D-7H & -82 & -63 & -62 & -90 & -57 \\
D-8H & 27 & 40 & 56 & 17 & 61 \\
\hline
\end{tabular}

*Os valores negativos observados na Tabela são referentes ao aumento da concentração dos compostos quando submetidos à irradiação.

Os compostos tetradecano, 2-metil heptadecano e 2-Metiloctadecano tiveram maior degradação com dose de 30 kGy, 42 e 48\% respectivamente, sendo que, com doses mais altas estes os compostos degradados continuam interagindo entre si e com radicais livres e polimerizam.

O composto nonacosano corresponde a hidrocarboneto de cadeia média que é formado como resultado da decomposição, tanto dos compostos aromáticos, como dos alifáticos de cadeias mais longas (tricontano), assim como pode também ter sido formado pela polimerização de radicais livres liberados.

De modo geral, a dose de 30 kGy mostrou-se mais eficiente na degradação dos compostos estudados. Nos compostos alifáticos, houve 
degradação acima de $40 \%$, o que sugere a produção de n-alcanos leves, ou seja, com menos de 14 carbonos.

\subsubsection{Compostos orgânicos nitrogenados}

Os principais compostos orgânicos nitrogenados encontrados no diesel com as respectivas identificações são apresentados na Tabela 8. Foram identificados cinco compostos principais, que são 0 metildihidro ciclopentapirazina, o metil benzenoetanamina, o dicarbonitrile benzeno, o tetrahidro fenil benzoxazocine e o etilamina carbazol. Todos são compostos aromáticos e apenas em dois deles o nitrogênio faz parte do anel aromático, 0 metildihidro ciclopentapirazina (D1N) e o etilamina carbazol (D5N).

Tabela 8. Compostos orgânicos nitrogenados identificados nas amostras de diesel

\section{Compostos Nitrogenados}

Nome

Metildihidro ciclopentapirazina

Metil benzenoetanamina

Dicarbonitrile benzeno

Tetrahidrofenil Benzoxazocine

Etilamina carbazol
Sigla

D-1N

D-2N

D-3N

D-4N

D-5N

\section{Formula Estrutural}<smiles>CC1Cc2nccnc21</smiles>

$\mathrm{NH}_{2}$<smiles>CC(CN)c1ccc(N=C2C=CC(=N)C=C2)cc1</smiles>

in
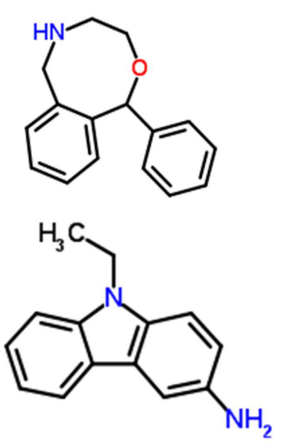
O comportamento da concentração desses compostos em função da dose absorvida de radiação é apresentado no gráfico da Figura 18. Os compostos Dicarbonitrile benzeno (D3N), tetrahidro fenil Benzoxazocine (D4N) e o etilamina carbazol (D5N), apresentaram concentrações maiores que os demais.

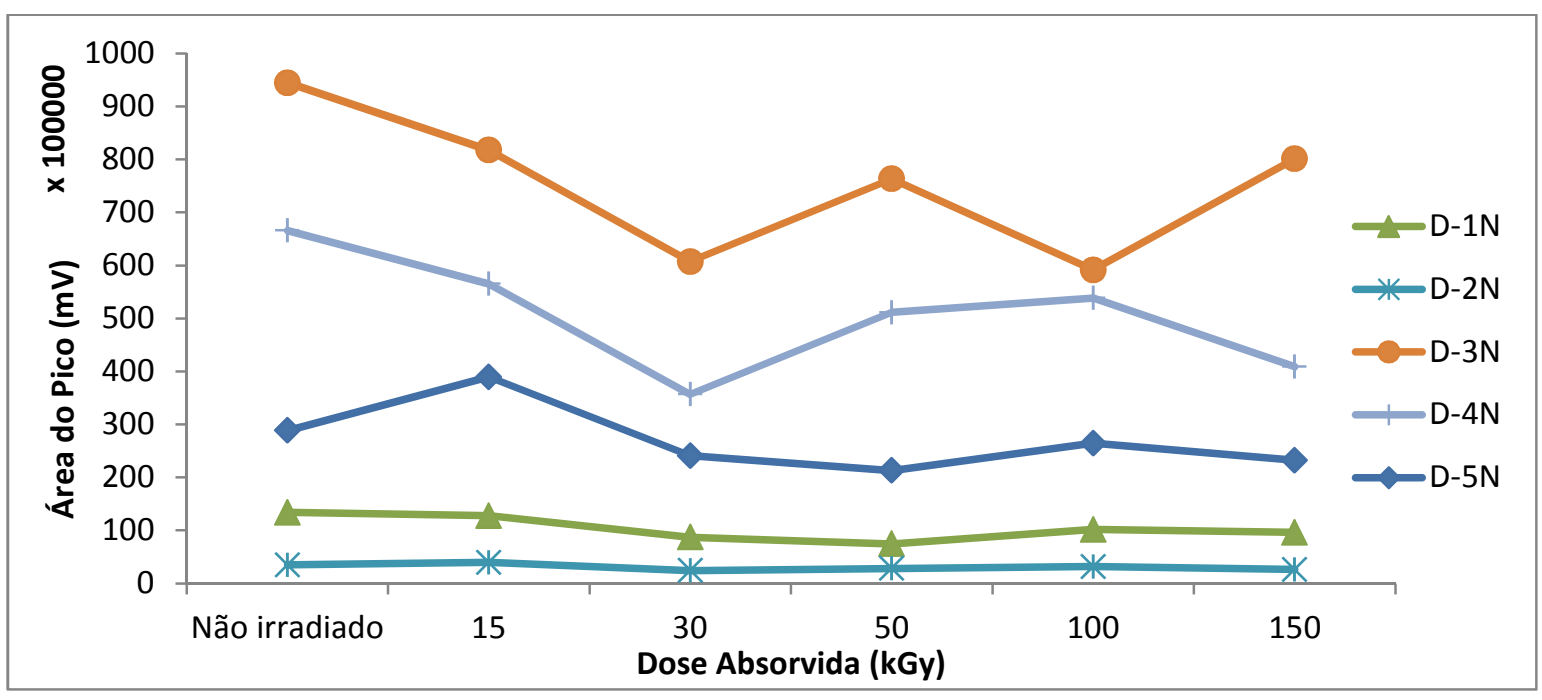

Figura 18. Variação da área do pico dos principais compostos nitrogenados no diesel em função da dose absorvida de radiação.

A variação das concentrações das amostras irradiadas em porcentagens relativa à amostra não irradiada é apresentada na Tabela 9 para as diferentes doses absorvidas.

Tabela 9. Degradação e /ou formação de compostos nitrogenados (\%) na amostra de diesel após a irradiação.

\begin{tabular}{c|ccccc}
\hline Sigla & \multicolumn{5}{c}{ Dose Absorvida (kGy) } \\
& $\mathbf{1 5}$ & $\mathbf{3 0}$ & $\mathbf{5 0}$ & $\mathbf{1 0 0}$ & $\mathbf{1 5 0}$ \\
\hline D-1N & 5 & 35 & 44 & 24 & 28 \\
D-2N & -13 & 31 & 19 & 10 & 25 \\
D-3N & 13 & 36 & 19 & 37 & 15 \\
D-4N & 15 & 46 & 23 & 19 & 39 \\
D-5N & -35 & 17 & 26 & 8 & 20 \\
\hline
\end{tabular}

${ }^{*}$ Os valores negativos observados na Tabela são referentes ao aumento da concentração dos compostos quando submetidos à irradiação. 
Todos os compostos apresentaram degradação maior que $30 \%$ com uma dose de $30 \mathrm{kGy}$, exceto o etilamina carbazol que reduziu $17 \%$ e aumentou $35 \%$ com a dose de $15 \mathrm{kGy}$, esse aumento pode ser resultado da decomposição do Tetrahidrofenil Benzoxazocine (D4N) que possui molécula semelhante só que mais complexa.

Cabe notar que os compostos 5-Metil-6,7-dihidro-(5H)ciclopentapirazina, 3,4,5,6-tetrahidro-1-fenil, 1H-2,5-Benzoxazocine e $9 \mathrm{H}$ Carbazol-3-amina, 9-etil são aromáticos e o nitrogênio esta no anel, logo a energia absorvida pela molécula não altera sua estrutura. Já os compostos Benzenoetanamina, beta.-metil e 1,4-Benzenedicarbonitrila apresentam maior degradação com doses de $30 \mathrm{kGy}$, e isso ocorre pois seus nitrogênios estão ligados ao anel aromático.

\subsubsection{Compostos orgânicos sulfurados}

Nas amostras de diesel foram identificados nove compostos sulfurados principais, sendo oito compostos com cadeia aromática e apenas um com cadeia alifática. Dos oito compostos aromáticos, o enxofre faz parte do anel em 5 deles e em 3 deles está ligado à parte alifática da molécula. Na Tabela 10 são apresentados todos os compostos sulfurados com a identificação e a fórmula estrutural. Os compostos DS-2, DS-4, DS-5 e DS-6 são derivados do benzotiofeno.

Tabela 10. Compostos orgânicos sulfurados identificados nas amostras de diesel

\begin{tabular}{ccc}
\hline Nome & Compostos Sulfurados \\
Sigla & $\mathrm{D}-1 \mathrm{~S}$ & 1-etilsulfinil buteno \\
Benzotiofeno & $\mathrm{D}-2 \mathrm{~S}$
\end{tabular}




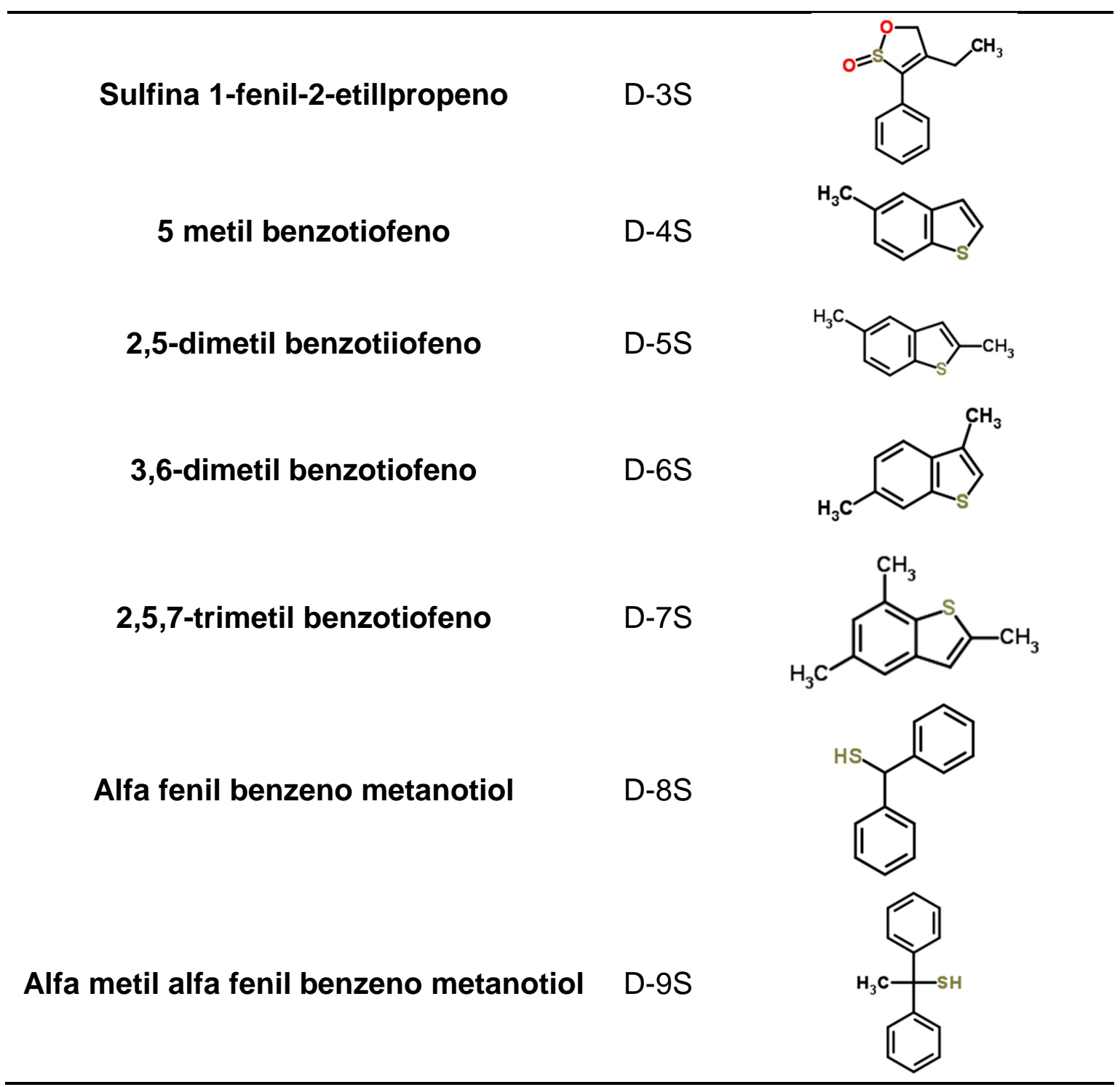

O composto presente em maior concentração foi o alfa fenil benzeno metanotiol (D-8S), seguido pelo alfa metil alfa fenil benzeno metanotiol,(D-9S) pelo trimetil benzotiofeno (D-7S) e pelo sulfina 1-fenil-2-etillpropeno (D-3S). Todos esses compostos são mais complexos, mas semelhantes ao benzotiofeno. $\mathrm{Na}$ Figura 19 é apresentado o gráfico com as variações de concentração de cada composto com a dose absorvida de radiação. 


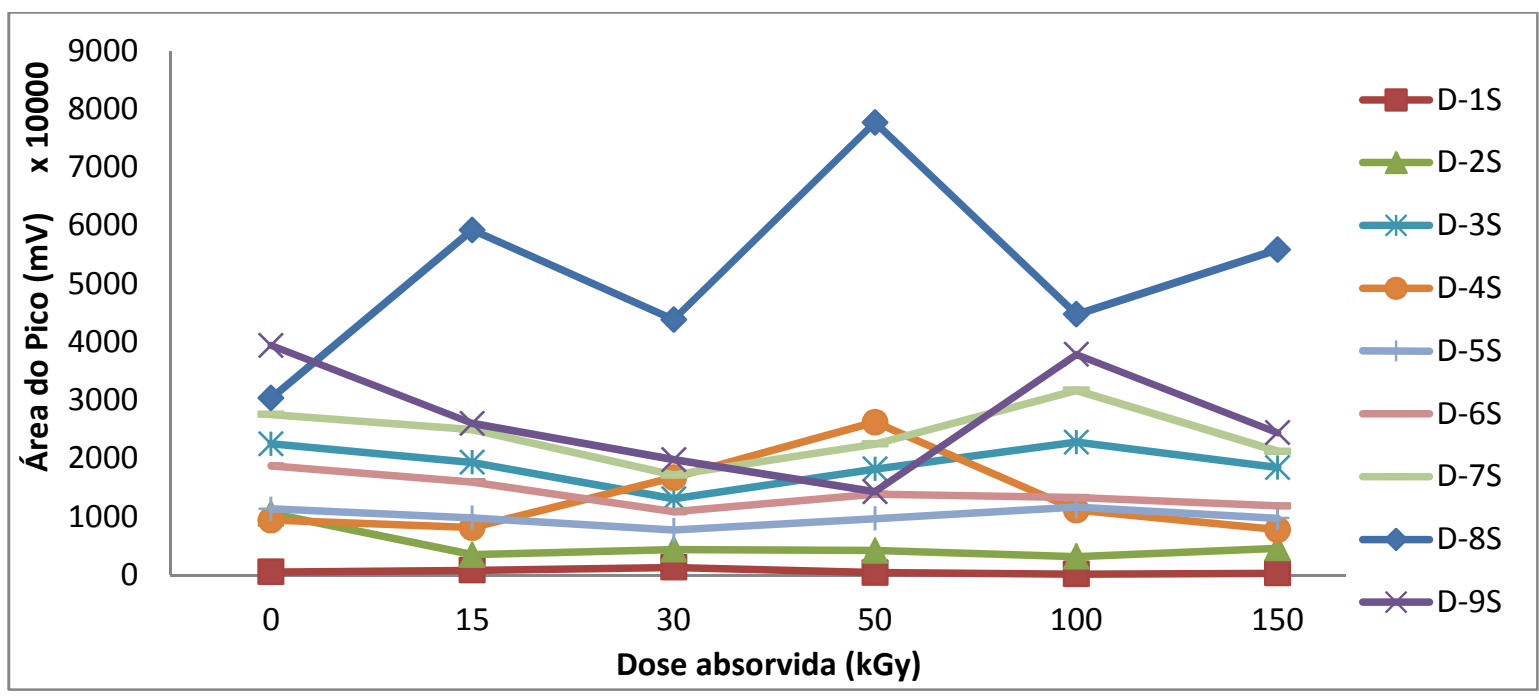

Figura 19. Variação da área do pico dos principais compostos sulfurados no diesel em função da dose absorvida de radiação

As variações nas concentrações após a irradiação foram calculadas em porcentagem relativa à amostra não irradiada, para todos os compostos e doses absorvidas e os resultados obtidos são apresentados na Tabela 11.

Tabela 11. Degradação e /ou formação de compostos sulfurados (\%) na amostra de diesel após a irradiação.

\begin{tabular}{c|ccccc}
\hline Sigla & \multicolumn{5}{c}{ Dose Absorvida (kGy) } \\
& $\mathbf{1 5}$ & $\mathbf{3 0}$ & $\mathbf{5 0}$ & $\mathbf{1 0 0}$ & $\mathbf{1 5 0}$ \\
\hline D-1S & -50 & -149 & 25 & 69 & 44 \\
D-2S & 67 & 58 & 60 & 70 & 57 \\
D-3S & 14 & 42 & 19 & -1 & 18 \\
D-4S & 14 & -77 & -178 & -18 & 18 \\
D-5S & 13 & 32 & 15 & -2 & 14 \\
D-6S & 15 & 42 & 26 & 29 & 37 \\
D-7S & 9 & 38 & 18 & -15 & 23 \\
D-8S & -95 & -44 & -156 & -47 & -84 \\
D-9S & 34 & 50 & 64 & 4 & 38 \\
\hline
\end{tabular}

${ }^{*}$ Os valores negativos observados na Tabela são referentes ao aumento da concentração dos compostos quando submetidos à irradiação. 
Analisando a Figura 19 e a Tabela 11 observa-se que houve redução na maioria dos compostos com doses absorvidas de até 50 kGy e, como resultado dessa decomposição, houve formação de outros que possuem moléculas mais simples. O composto de que mais aumentou com $15 \mathrm{kGy}$ e 30 kGy foi o de molécula alifática mais simples, o etilsulfinil buteno,, o que é esperado uma vez que ele pode ter sido liberado da degradação dos outros compostos aromáticos, principalmente aqueles cujo enxofre fazia parte do anel, como o benzotiofeno e seus derivados.

O composto benzotiofeno, degradou mais de $50 \%$ em todas as doses, sendo a dose de $100 \mathrm{kGy}$ a que apresentou melhor eficiência com remoção de 70\%. O compostos, 2,5-dimetilbenzotiofeno (D-4S) e alfa fenil benzeno metanotiol (D-8S) apresentaram um aumento de mais de $150 \%$ com a dose de $50 \mathrm{kGy}$, em contrapartida os compostos 3,6-dimetil, benzotiofeno etrimetil benzotiofeno reduziram $58 \%$ e, $38 \%$ respectivamente, com a dose de $30 \mathrm{kGy}$. A partir destes dados supõe-se que houve a formação de radicais $\mathrm{C}_{n} \mathrm{H}_{2 n+1}$, que recombinados com hidrocarbonetos saturados gerados aumentam a concentração de benzotiofeno mono-substituidos.

Para os compostos alfa.-fenil benzenometanotiol e alfa.-metil-.alpha.fenil benzenometanetiol, a radiação interagiu majoritariamente $\mathrm{CH}_{3}$ da molécula alfa.-metil-.alpha.-fenil benzenometanetiol o que consequentemente fez com que a concentração da Alfa.-fenil benzenometanotiol aumentasse na dose de $50 \mathrm{kGy}$.

\subsubsection{Espectroscopia do Infravermelho}

As análises de espectroscopia de FTIR foram realizadas nas amostras sem irradiar e após a irradiação para avaliar se houve alguma alteração na composição óleo diesel (Apêndice B), entretanto, tais mudanças não foram perceptíveis, isto porque as bandas de absorção observadas no espectro são resultado da vibração molecular e da composição da amostra predominantes, carbono e hidrogênio. 


\subsection{Avaliação do efeito da radiação ionizante no Petróleo}

A avaliação do efeito da radiação nas amostras de petróleo foram realizadas 20 dias após o processamento por radiação, para estas serão apresentados resultados considerando-se as análises realizadas por fluorescência de raios- $x$, para determinar a concentração total de enxofre, e avaliação da variação dos compostos orgânicos, analisados por GC-MS.

Devido a complexidade do petróleo em relação ao diesel, foi necessário o estudo de técnicas de separação química como a destilação e a separação cromatográfica em coluna aberta com cloreto de paládio e com carvão ativo, antes deste ser submetido à análise no GC-MS. Desse modo, os resultados obtidos serão apresentados, considerando essas etapas.

\subsubsection{Fluorescência de Raios-x}

Os parâmetros utilizados nas análises de fluorescência de raio- $X$ do petróleo foram os mesmos utilizados nas análises de óleo diesel, apresentados no item 3.2.1.

A concentração total de enxofre no petróleo não irradiado foi de $6330 \pm$ $16 \mathrm{mg} \cdot \mathrm{L}^{-1}$ e após a irradiação houve uma pequena redução de cerca de $5 \%$ para uma dose absorvida de $15 \mathrm{kGy}$, ou seja, o enxofre continua presente nas frações do petróleo, esses resultados são apresentados na Tabela 12.

Tabela 12.Concentração de enxofre molecular total nas amostras de petróleo não irradiada e irradiada com diferentes doses

\begin{tabular}{cc}
\hline $\begin{array}{c}\text { Dose Absorvida } \\
\text { (kGy) }\end{array}$ & $\begin{array}{c}\text { Concentração de enxofre no } \\
\text { Petróleo } \text { mg.L }^{-1}\end{array}$ \\
\hline Não irradiada & $6330 \pm 16$ \\
$\mathbf{1 5}$ & $6012 \pm 60$ \\
$\mathbf{3 0}$ & $6349 \pm 51$ \\
\hline
\end{tabular}




\subsubsection{Destilação do Petróleo}

A destilação do petróleo foi realizada com o intuito de facilitar a separação química dos compostos orgânicos, mas foi importante também como simulação da destilação realizada nas refinarias para o craqueamento térmico, ou seja, quebra dos hidrocarbonetos alifáticos de cadeias muito longas em cadeias menores.

No processo de destilação do petróleo foram controladas as temperaturas no balão de destilação e também no topo da coluna, onde passam as diferentes frações na forma de vapor. A variação dessas temperaturas para cada dose de radiação é apresentada no gráfico da Figura 20. No caso do petróleo bruto, a temperatura no topo da coluna foi mais elevada atingindo $140^{\circ} \mathrm{C}$ quando o balão de destilação foi aquecido a $400^{\circ} \mathrm{C}$ (ASTM1160) e na faixa $350 \mathrm{a}$ $400^{\circ} \mathrm{C}$ apresentou um patamar indicando a presença de hidrocarbonetos mais pesados. Para as amostras irradiadas nas diferentes doses, a temperatura no topo da coluna foi menor indicando a presença de hidrocarbonetos mais leves. As menores temperaturas foram obtidas quando a amostra de petróleo foi irradiada com dose absorvida de $15 \mathrm{kGy}$, para doses maiores, as temperaturas no topo da coluna voltaram a aumentar. A massa do petróleo antes da destilação e o volume do destilado foram medidos para a amostra não irradiada e irradiada nas diferentes doses absorvidas e, através pela densidade aparente do petróleo calculou-se o rendimento médio da destilação, obtendo-se o valor de $52 \pm 6 \%$. 


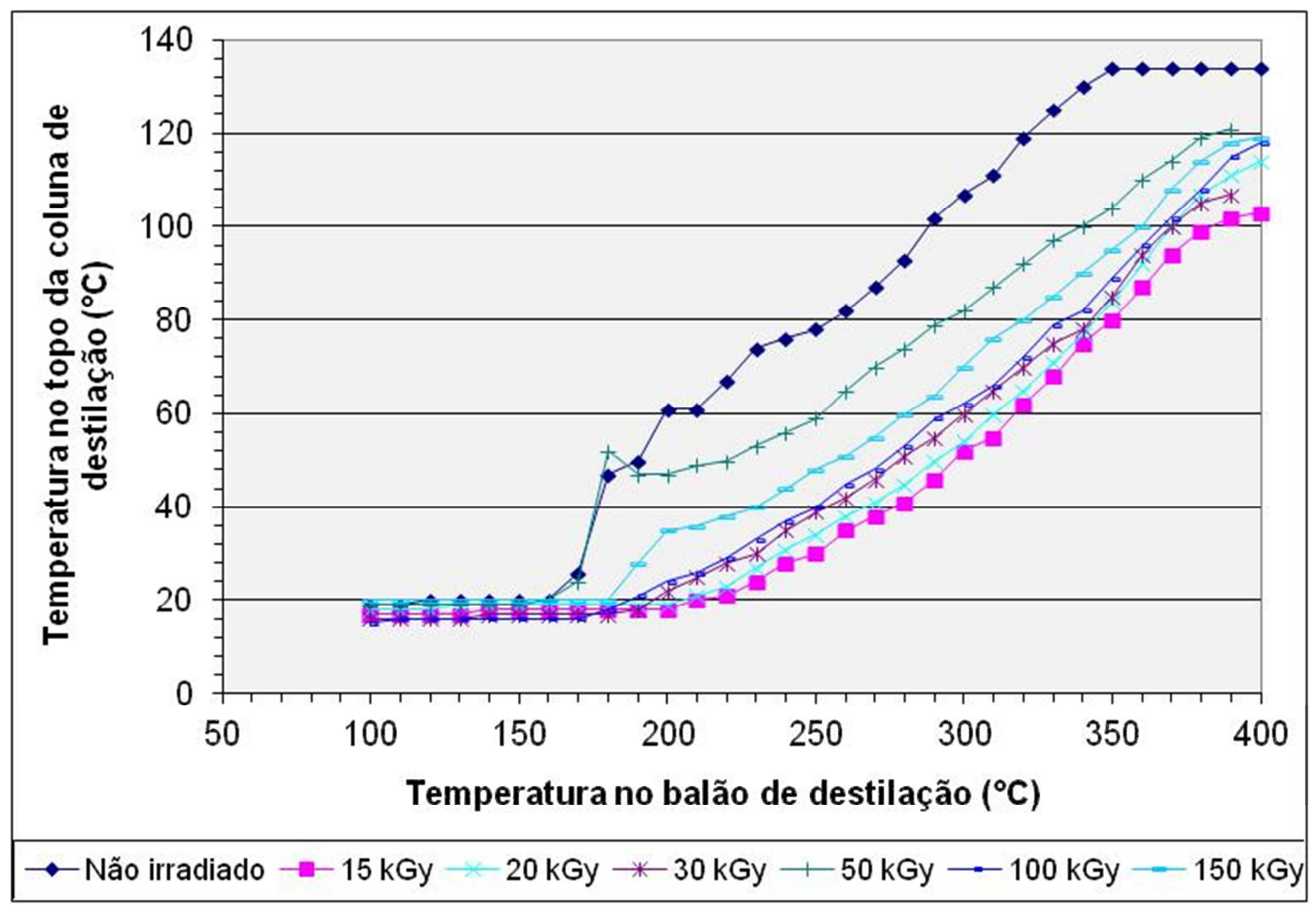

Figura 20. Variação da temperatura no fundo e topo da coluna com diferentes doses de irradiação

A influência da dose absorvida de radiação no comportamento da temperatura no topo da coluna em relação á do balão de destilação, pode ser visualizada melhor no gráfico apresentado na Figura 21. Nas temperaturas iniciais, $100^{\circ} \mathrm{C}$ e $150^{\circ} \mathrm{C}$, nota-se que a temperatura no topo permanece praticamente estável nas diferentes amostras, a partir de $200^{\circ} \mathrm{C}$ a temperatura no topo da coluna começa a variar para todas as doses absorvidas, mas decaindo significativamente para as doses de $15 \mathrm{kGy}$ e $20 \mathrm{kGy}$ e voltando a subir nas doses de $30 \mathrm{kGy}$ e $50 \mathrm{kGy}$. Esse comportamento pode explicar o efeito da radiação ionizante na decomposição ou craqueamento dos hidrocarbonetos mais pesados presentes no petróleo, ou seja, compostos mais leves foram gerados e portanto a destilação ocorre em temperaturas mais baixas. Sob outro ponto de vista, com a taxa de dose elevada, observa-se que a destilação começa a ter novamente característica do petróleo não irradiado, isso se dá em virtude da polimerização dos hidrocarbonetos causada pela recombinação dos radicais livres formados pela interação da radiação. 


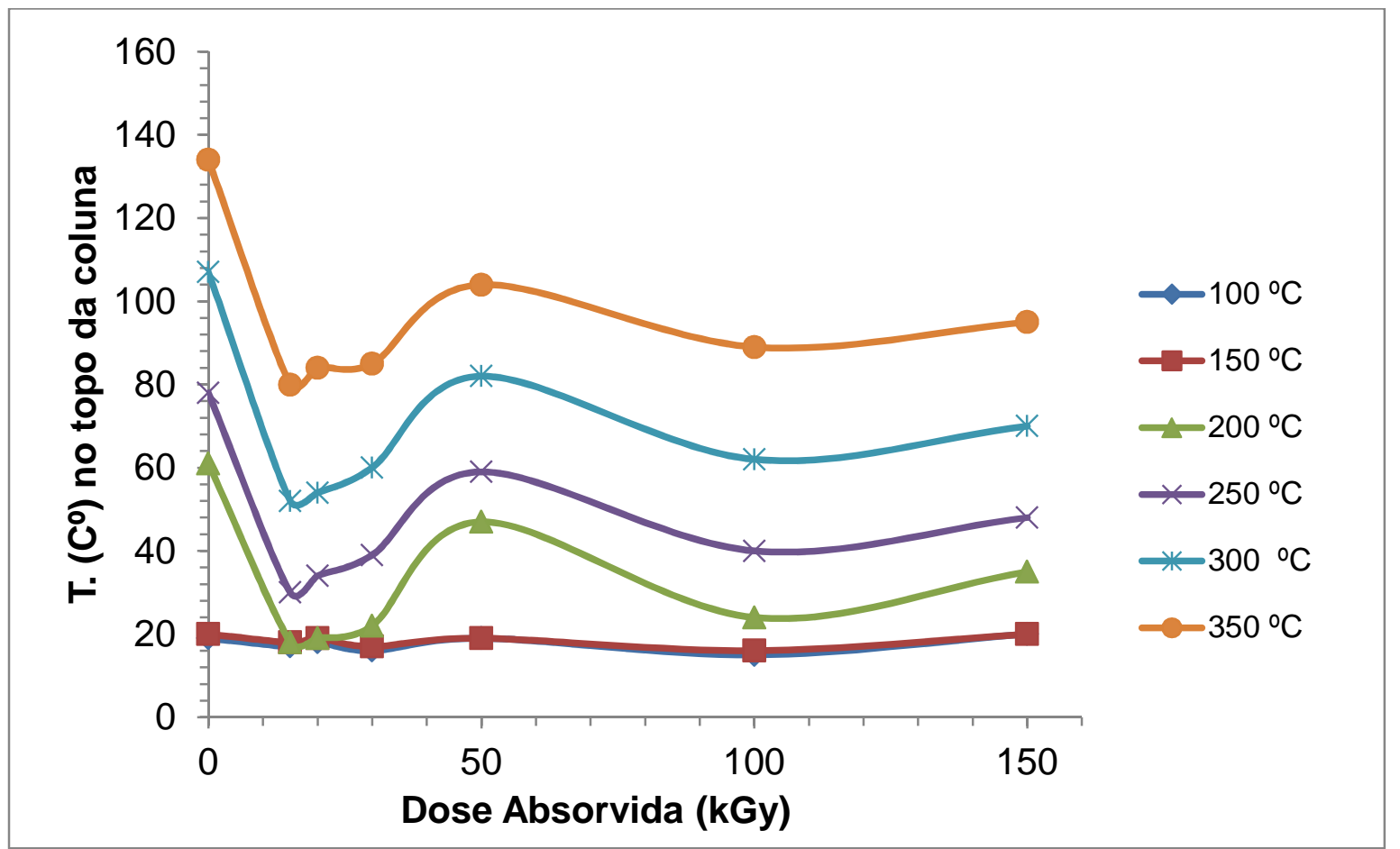

Figura 21. Variação da temperatura no topo da coluna com a temperatura fixa e diferentes doses de radiação.

Os resultados da concentração de enxofre total no destilado para a amostra não irradiada e irradiada nas diferentes doses, realizado por fluorescência de raios-x, são apresentados na Tabela 13. Esses resultados apresentaram o mesmo comportamento apresentado pela variação da temperatura na destilação, com uma redução significativa no teor de enxofre para doses de 15 kGy e 30 kGy, de cerca de 53\%. Esses resultados confirmam dados da literatura obtidos com petróleo da Arábia Saudita (Basfar, 2011) e Casaquistão (Zaykina et al, 2002). 
Tabela 13. Teor de enxofre nas amostras de petróleo destilados em relação a dose de radiação

\begin{tabular}{ccc}
\hline Dose (kGy) & $\begin{array}{c}\text { Concentração de } \\
\text { enxofre (mg/L) }\end{array}$ & \% de dessulfurização \\
\hline $\mathbf{0}$ & $1485 \pm 14$ & 0,00 \\
$\mathbf{1 5}$ & $709 \pm 42$ & 52,26 \\
$\mathbf{3 0}$ & $699 \pm 50$ & 52,92 \\
$\mathbf{5 0}$ & $1367 \pm 23$ & 7,95 \\
$\mathbf{1 0 0}$ & $1299 \pm 20$ & 12,53 \\
$\mathbf{1 5 0}$ & $1482 \pm 20$ & 0,20 \\
\hline
\end{tabular}

\subsubsection{Efeito da radiação nos compostos orgânicos do Petróleo}

Nas amostras de petróleo foram analisados separadamente os compostos orgânicos sulfurados, os compostos orgânicos nitrogenados e os hidrocarbonetos, estes foram identificados com as siglas PS, PN e PH, respectivamente.

\subsubsection{Compostos orgânicos sulfurados}

Para a separação por cromatografia de coluna aberta dos compostos sulfurados, utilizou-se diferentes fases estacionarias, e posteriormente realizou-se a análise por GC-MS, os resultados serão apresentados a seguir.

\section{Separação usando cloreto de paládio}

Após a irradiação, com doses de 30kGy e 50 kGy, e destilação das amostras de petróleo, que produziu uma fração mais leve, com a qual realizou-se a cromatográfica de coluna aberta, sendo o cloreto de paládio utilizado como fase estacionaria, elui-se a amostra do destilado com uma mistura de solventes, os compostos cíclicos e aromáticos foram separados dos compostos alifáticos. Entretanto, compostos alifáticos de alto peso molecular, como 0 1- 
heptadecanotiol coeluiram juntamente com a fração dos compostos cíclicos e aromáticos. Na Tabela 14 são apresentadas os nomes, as siglas que serão usadas para estes compostos no presente trabalho e as fórmulas estruturais dos compostos orgânicos sulfurados.

Tabela 14 . Compostos orgânicos sulfurados identificados nas amostras de petróleo após separação cromatográfica usando cloreto de paládio.

\begin{tabular}{|c|c|c|}
\hline Nome & Sigla & Formula estrutural \\
\hline 4-Fluorotiofenol & PS1 & \\
\hline 4,6-dimetil-1H,3H-tieno 3,4-c tiofeno, & PS2 & \\
\hline 5-Hidroxi-2-metiltiopirimidina & PS3 & \\
\hline 2,6-Dimetil-3-formiltiaciclohex-3-eno & PS4 & \\
\hline Ciclohexano, isotiocianato & PS5 & \\
\hline Ácido 1,2-ditiolane-3 pentanoíco & PS6 & \\
\hline 1-Heptadecanotiol & PS7 & \\
\hline $\begin{array}{l}\text { 4,5-Dimetiltetrahidro-1,3-oxazine-2- } \\
\text { tione }\end{array}$ & PS8 & \\
\hline
\end{tabular}


Ácido benzenossulfônico, 4-metil-, dodecil ester

PS9

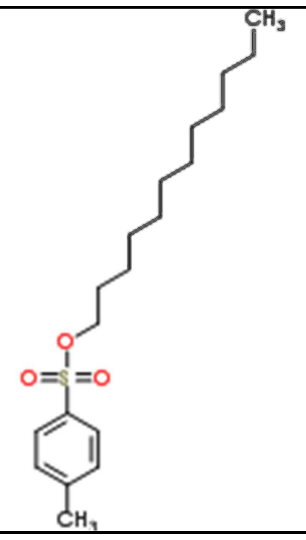

Para melhor compreensão do efeito da radiação nestes compostos, construiu-se o gráfico apresentado na Figura $22 \mathrm{com}$ a área do pico, dos compostos identificados na Tabela 14, em função da dose absorvida. Neste observa-se que a dose de 50 kGy a obteve maior eficiência.

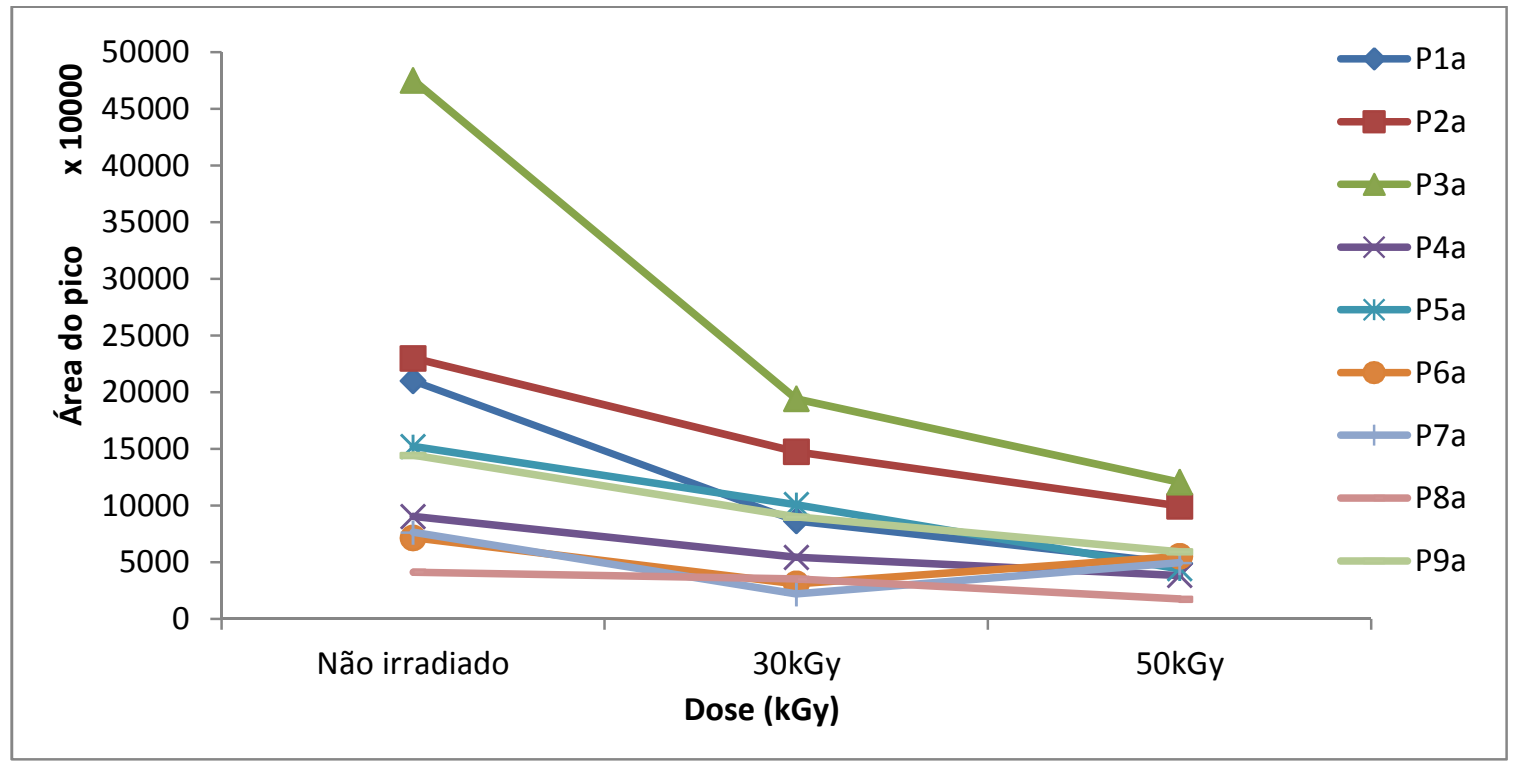

Figura 22. Variação da área do pico dos principais compostos sulfurados no petróleo, separados por coluna de cloreto de paládio, em função da dose absorvida de radiação

As variações nas concentrações foram calculadas em forma de porcentagem de remoção dos compostos em relação a amostra não irradiada, os resultados são apresentados na Tabela 15 . Os compostos sulfurados apresentaram reduziram consideravelmente com a radiação, sendo que o 4- 
fluorotiofenol , o 5-hidroxi-2-metilopirimidina e ciclohexano isotiocianato que apresentaram as maiores remoções com $77 \%, 75 \%$ e $71 \%$, respectivamente, para a dose absorvida de $50 \mathrm{kGy}$. Os demais compostos de enxofre apresentaram uma redução de aproximadamente 50\%, com exceção do 4,5-dimetiltetrahidro1,3-oxazine-2-tione e ácido benzenossulfônico-4-metil-dodecil ester que apresentaram melhores resultados com 30 kGy, com remoções de $57 \%$ e $71 \%$, respectivamente.

Tabela 15. Remoção de compostos de enxofre (\%) da amostra de petróleo após a irradiação com 30 kGy e 50 kGy de doses absorvidas

\begin{tabular}{c|cc|c|cc}
\hline Sigla & \multicolumn{2}{|c|}{ Dose Absorvida (kGy) } & Sigla & \multicolumn{2}{c}{ Dose Absorvida (kGy) } \\
& 30 kGy & $\mathbf{5 0 ~ k G y ~}$ & & 30 kGy & 50 kGy \\
\hline PS1 & 59 & 77 & PS6 & 38 & 59 \\
PS2 & 15 & 57 & PS7 & 36 & 57 \\
PS3 & 59 & 75 & PS8 & 57 & 23 \\
PS4 & 40 & 58 & PS9 & 71 & 35 \\
PS5 & 34 & 71 & & & \\
\hline
\end{tabular}

Um dos fatores que deve-se notar na redução dos compostos sulfurados, esta na forma com a qual o enxofre se liga ao carbono, desta forma compostos como o PS-1, PS-3 e PS-5, que não possuem enxofres dentro do anel cíclico ou aromático reduziram mais facilmente com a dose de $50 \mathrm{kGy}$, pois suas ligações são mais fracas.

Em contrapartida os compostos como PS-2, PS-4, PS-6, cujo enxofre esta no anel cíclico e ou aromático, tendem reduzir em menor proporção se comparado a outros compostos, sendo que sua redução pode estar relacionado a quebra das ligações externas, ou seja $\mathrm{CH}_{3}$, e não propriamente a quebra do anel, que redistribui a energia proveniente da radiação.

Ainda deve-se considerar a presença oxigênio e o nitrogênio, como nas moléculas PS-8 e PS-9, que interagem majoritariamente e competitivamente com 
o enxofre pelos elétrons gerados no processo de radiação. Além disto, impedimentos estéricos dificultam a interação destes elétrons com o enxofre.

\section{Separação usando carvão ativo}

Nesta etapa, após a irradiação e destilação do petróleo, fez se a separação cromatográfica em coluna aberta, utilizando como fase estacionaria carvão ativo, visando diminuir os custos da análise. A partir da eluição do destilado, obteve-se a fração que foi analisada por GC-MS. Nesta observou-se a coleuição dos compostos cíclicos, aromáticos e alifáticos.

Um dos fatores que mais se ressalta na análise dos compostos sulfurados como resultado deste método é o aparecimento de isômeros e a pequena quantidade de compostos identificados. Na Tabela 16 são apresentados os nomes, as siglas usadas no presente trabalho e suas respectivas formulas estruturais .

Tabela 16 . Compostos orgânicos sulfurados identificados nas amostras de petróleo após separação cromatográfica usando carvão ativo.

Compostos sulfurados
Sigla
Dimetil 1,5-Pentanodiol sulfonato




\section{4,5-Dimetil tetrahidro-1,3-oxazina-2- tiona}

\section{4,5-Dimetil tetrahidro-1,3-oxazina-2- tiona}

P-5S<smiles>C=C1COC(=O)[C@H](C)C1</smiles>

P-6S<smiles>CC1COC(=S)NC1C</smiles>

Para auxiliar visualização do efeito da radiação nos compostos orgânicos sulfurados, foi com construído o gráfico apresentado na Figura $23 \mathrm{com}$ a área de cada pico, do compostos indicados na Tabela 16, nesta observa-se que a dose mais eficiente foi a de 50 kGy onde a maioria dos compostos reduziram, enquanto com outras doses apresentaram baixa eficiência na remoção ou aumento da concentração.

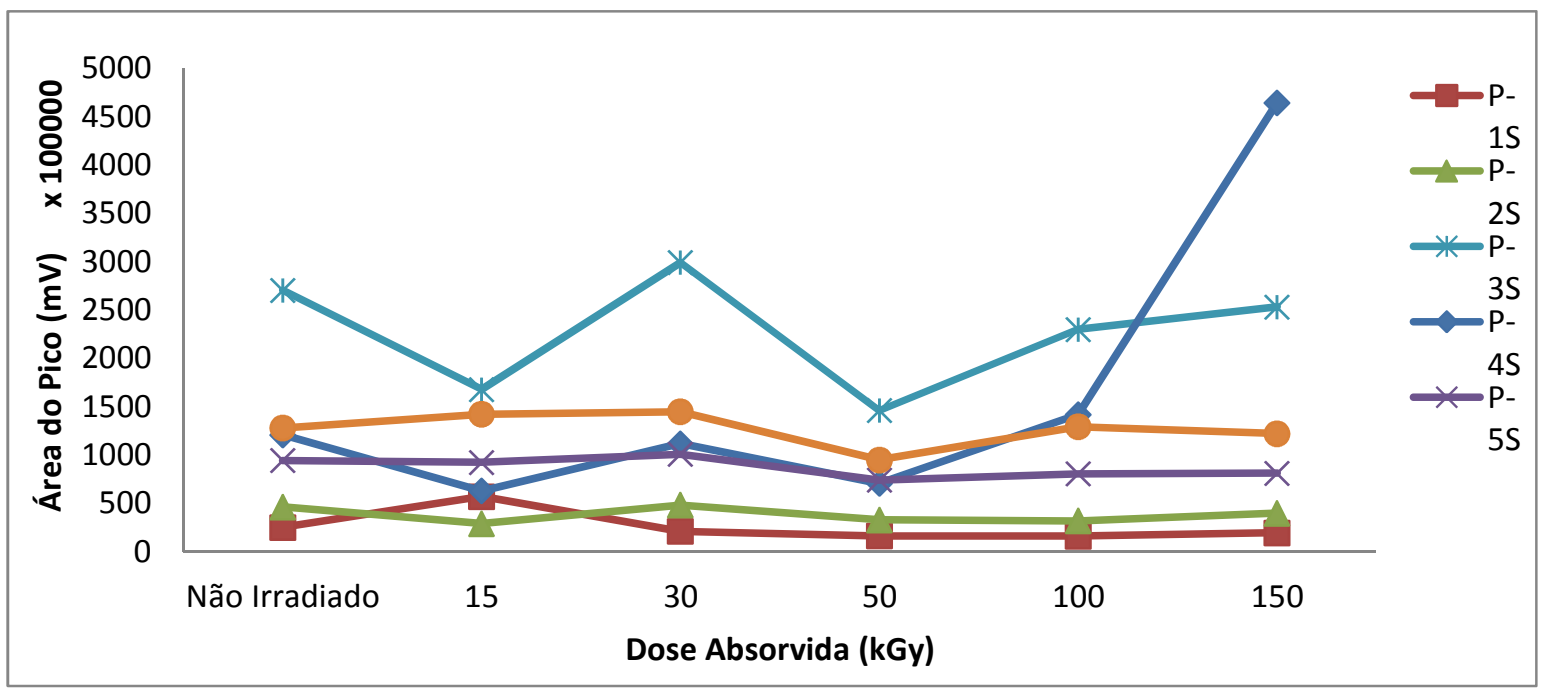

Figura 23. Variação da área do pico dos principais compostos sulfurados no petróleo, separados por coluna de carvão ativo, em função da dose absorvida de radiação

As variações nas concentrações foram calculadas em forma de porcentagem relativa à amostra não irradiada, os resultados obtidos são apresentados na Tabela 17. De modo geral, observa-se que os isômeros dos compostos sulfurados, apresentam um comportamento distinto nas mesma doses, com por exemplo, o P-3S e P-4S que na dose de 150 kGy, que apresentam 
redução de $6 \%$ e aumento de $285 \%$ respectivamente. Entretanto para estes compostos, bem como para os P-5S E P-6S, nota-se um comportamento semelhante é observado na dose de 50 kGy, ou seja as porcentagens de degradação são muito próximas.

Tabela 17. Remoção de compostos sulfurados (\%) da amostra de petróleo após a irradiação

\begin{tabular}{c|ccccc}
\hline Sigla & \multicolumn{5}{c}{ Dose Absorvida (kGy) } \\
& $\mathbf{1 5}$ & $\mathbf{3 0}$ & $\mathbf{5 0}$ & $\mathbf{1 0 0}$ & $\mathbf{1 5 0}$ \\
\hline P-1S & ${ }^{*}-127$ & 16 & 36 & 37 & 22 \\
P-2S & 37 & ${ }^{*}-4$ & 29 & 31 & 14 \\
P-3S & 38 & $*-11$ & 46 & 15 & 6 \\
P-4S & 48 & 8 & 42 & $*-17$ & ${ }^{*}-285$ \\
P-5S & 2 & $*-7$ & 22 & 15 & 14 \\
P-6S & ${ }_{-}-11$ & $*-13$ & 26 & ${ }^{*}-1$ & 5 \\
\hline
\end{tabular}

*Os valores negativos observados na Tabela são referentes ao aumento da concentração dos compostos quando submetidos à irradiação.

O composto P-1S tem sua concentração elevada com a dose de 15 kGy, e é degradado com doses 50 e 100 kGy. Já o composto P-2S degrada $37 \%$ com a dose de 15 kGy. O composto P-3S isômero do P-4S, P-5S isômero P-6S, apresentam maior degradação com a dose de 50 kGy.

Para os compostos sulfurados estudados a partir da separação com carvão ativo, deve-se notar que os átomos de enxofre estão fora de anéis cíclicos e aromáticos, de forma que radicais livres contendo enxofre podem ter sido gerados a partir da interação com a radiação e estes por serem instáveis se recombinam com outros compostos, dentre eles os próprios anéis cíclicos e aromáticos.

\section{Separação com cloreto de paládio versus separação carvão ativo}

A separação do destilado de petróleo por cromatografia de coluna aberta, utilizando duas fases estacionarias distintas tinha como intuito estudar os 
compostos orgânicos sulfurados e seu comportamento perante a radiação ionizante. A partir do estudo utilizando o cloreto de paládio como fase estacionaria observou-se a separação mais eficiente dos compostos sulfurados, nove compostos foram identificados, também foi possível determinar de forma efetiva a melhor dose para a degradação dos compostos que foi de 50 kGy, entretanto o uso do cloreto de paládio elevaria os custos da análise.

A utilização do carvão ativo como fase estacionaria resultou na baixa eficiência da separação entre os compostos aromáticos, cíclicos e alifáticos, nesta identificou-se seis compostos orgânicos sulfurados, entretanto foi possível observar o comportamento dos isômeros, com diferentes doses, e conforme a análise utilizando cloreto de paládio, também determinou-se que a dose mais eficiente na degradação dos compostos foi de 50 kGy. Cabe ressaltar que a partir da utilização desta fase, tornou-se possível avaliar os hidrocarbonetos e compostos nitrogenados que serão discutidos a seguir, além de reduzir os custos da análise.

\subsubsection{Hidrocarbonetos}

Os hidrocarbonetos presentes no petróleo destilados, foram identificados após a separação cromatográfica de coluna aberta, usando como fase estacionaria o carvão ativo, seguido da análise por GC-MS. Na tabela 18 são apresentados os nomes dos hidrocarbonetos, suas siglas e respectivas formulas moleculares que serão utilizadas neste trabalho.

Tabela 18. Principais hidrocarbonetos identificados nas amostras de petróleo destilado após separação cromatográfica usando cloreto de paládio.

\begin{tabular}{|c|c|c|}
\hline \multicolumn{3}{|c|}{ Hidrocarbonetos alifáticos e aromáticos } \\
\hline Nome & Sigla & Formula Estrutural \\
\hline 3,7-dimetil- nonano (C11) & $\mathrm{P}-1 \mathrm{H}$ & \\
\hline 3,4-dimetil-1-Deceno (C12) & $\mathrm{P}-2 \mathrm{H}$ & \\
\hline
\end{tabular}


3-metil-hexadecano (C17)

Nonadecano (C19)

Heneicosano (C21)

Docosano (C22)

Pentatriacontano (C35)

cis 1-etil-2-metil-ciclopentano

1-etenil-3-metileno-ciclopenteno

1,3,5-trimetil- benzeno,

Undecil- benzeno
$\mathrm{P}-3 \mathrm{H}$

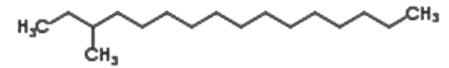

P-4H

$\mathrm{P}-5 \mathrm{H}$

P-6H

$\mathrm{P}-7 \mathrm{H}$

$\mathrm{P}-8 \mathrm{H}$<smiles>CCC1CCCC1C</smiles>

P-9H<smiles>C=CC1=CC(=C)CC1</smiles>

P-10H<smiles>Cc1cc(C)cc(C)c1</smiles>

P-11H

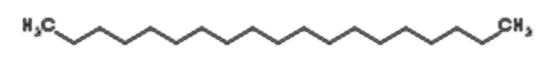

Hochors
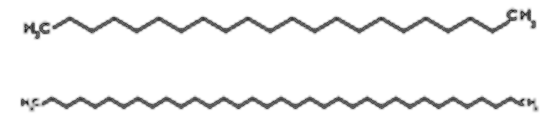

Para a melhor visualização do efeito da radiação ionizante nesses compostos, construiu-se o gráfico da Figura $24 \mathrm{com}$ a área do pico, de cada compostos identificado na Tabela 18, em função da dose absorvida de radiação. Nesta observa-se que hidrocarbonetos alifáticos, com cadeia carbônica media e longa, como o nonacosano, heneicosano, docosano e o pentatriacontano e o hidrocarboneto cíclico , 1-etenil, 3-metil ciclopenteno, tiveram concentrações mais elevadas, com relação aos outros hidrocarbonetos identificados, em todas as doses estudadas. Ainda nota-se a diminuição da concentração de alguns compostos nas doses de 15 kGy e 50 kGy e o aumento em outras doses. 


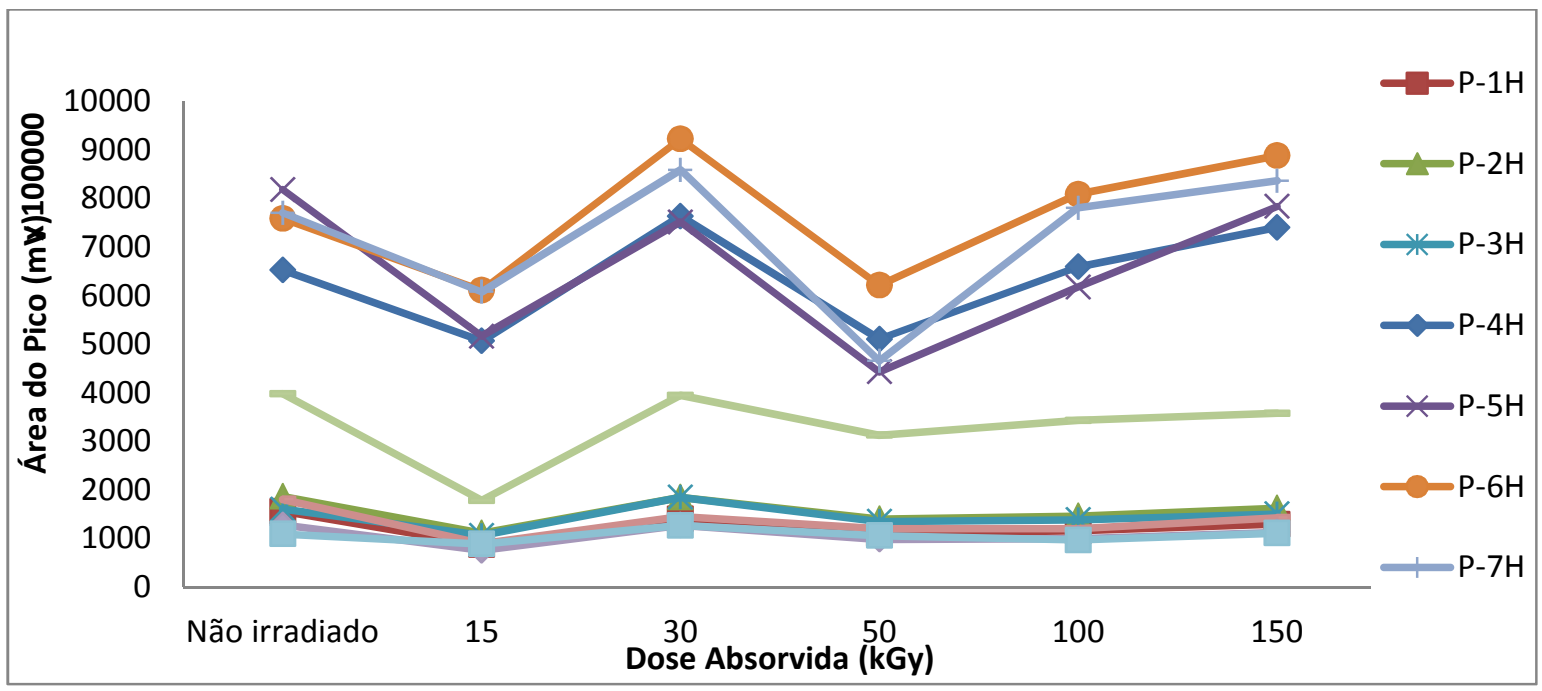

Figura 24. Relação entre a área e a dose dos hidrocarbonetos no petróleo.

As variações nas concentrações em relação a amostra não irradiada, foram calculadas em forma de porcentagem, os resultados são apresentados na Tabela 19.

Tabela 19. Remoção de compostos de enxofre (\% ) da amostra de petróleo após a irradiação

\begin{tabular}{c|ccccc}
\hline Sigla & \multicolumn{5}{c}{ Dose Absorvida (kGy) } \\
& $\mathbf{1 5}$ & $\mathbf{3 0}$ & $\mathbf{5 0}$ & $\mathbf{1 0 0}$ & $\mathbf{1 5 0}$ \\
\hline $\mathbf{P}-\mathbf{1 H}$ & 44 & 10 & 30 & 26 & 17 \\
$\mathbf{P}-\mathbf{2 H}$ & 40 & 1 & 25 & 22 & 13 \\
$\mathbf{P}-3 \mathbf{H}$ & 34 & ${ }^{*}-15$ & 16 & 14 & 6 \\
$\mathbf{P}-\mathbf{4 H}$ & 22 & ${ }^{*}-17$ & 22 & ${ }^{*}-1$ & ${ }^{*}-13$ \\
$\mathbf{P}-\mathbf{5 H}$ & 37 & 8 & 46 & 25 & 4 \\
$\mathbf{P}-\mathbf{6 H}$ & 19 & ${ }^{*}-22$ & 18 & ${ }^{*}-7$ & ${ }^{*}-17$ \\
$\mathbf{P}-\mathbf{7 H}$ & 21 & ${ }^{*}-11$ & 40 & $-{ }^{*} 1$ & ${ }^{*}-9$ \\
$\mathbf{P}-\mathbf{8 H}$ & 51 & 20 & 33 & 33 & 21 \\
$\mathbf{P}-9 \mathbf{H}$ & 55 & 1 & 21 & 14 & 10 \\
$\mathbf{P}-\mathbf{1 0 H}$ & 41 & 0 & 23 & 22 & 12 \\
$\mathbf{P}-\mathbf{1 1 H}$ & 19 & ${ }^{*}-16$ & 3 & 12 & ${ }^{*}-2$ \\
\hline${ }^{*}$ Os valores negativos observados na Tabela são referentes ao aumento da concentração \\
dos compostos quando submetidos à irradiação.
\end{tabular}


Dentre os compostos alifáticos, 3,7-dimetil- nonano, 3,4-dimetil-1deceno, 3-metil-hexadecano e nonadecano, observa-se o fenômeno de craqueamento de modo superior com as doses de $15 \mathrm{kGy}$ e $50 \mathrm{kGy}$, isto significa que para a quebra das ligações simples não é necessário uma dose absorvida elevada, ou seja, a aplicação da radiação ionizante diminui a energia necessária para que ocorra o craqueamento, diferentemente do que ocorre no hidrocraqueamento, como foi constatado por Zaykin em 2013.

Com a dose de 30 kGy os compostos 3-metil-hexadecano e nonadecano tiveram sua concentração ligeiramente elevada, isto sugere que houve a polimerização destes, em contrapartida com doses de 100 e 150 kGy observou-se que a degradação não foi eficiente, isto se da devido a interação de fragmentos menores com radicais livres, ou seja, recombinação destes compostos.

Para os compostos alifáticos, heneicosano, docosano e pentatriacontano, com peso molecular maior notou-se que a degradação mais eficiente ocorreu mais com a dose de 50 kGy, com doses de 100 kGy e 150 kGy esse compostos degradaram pouco e ou tiveram suas concentrações elevadas.

Os hidrocarbonetos cíclicos e aromáticos, 1-etil-2-metil-, cisciclopentano, 1-etenil-3-metileno-ciclopenteno, 1,3,5-trimetil-benzeno e undecilbenzeno, obtiveram a maior degradação com a dose de 15kGy. Para estes devese considerar que a existência de cadeias laterais ligados ao anel cíclico e ao aromáticos, sendo que a degradação dos mesmo se da devido a quebra destas ramificações, uma vez que ligações conjugadas tendem a ser resistentes a radiação. A quebra destas cadeias laterais colabora para que ocorra a polimerização em especial em doses elevadas, como as de 100 kGy e 150kGy, que neste caso justificaria o aumento dos hidrocarbonetos alifáticos de alto peso molecular.

\subsubsection{Nitrogenados}


Os principais compostos orgânicos nitrogenados presentes no destilado de petróleo, suas siglas e suas formulas estruturais são expostos na Tabela 20. Foram identificados oito compostos, todos aromáticos sendo que apenas quatro compostos apresentam o nitrogênio como parte do anel aromáticos, ainda observou-se que os $\mathrm{N}$-(fenilmetil)-benzenometanamina, Etinil-, carbamato ciclohexanol e 5-Metil-6,7-dihidro-(5H)-ciclopentapirazina apresentaram maiores concentrações nas amostras estudadas.

Tabela 20. Compostos orgânicos nitrogenados identificados nas amostras de petróleo

\begin{tabular}{|c|c|c|}
\hline \multicolumn{3}{|c|}{ Compostos nitrogenados } \\
\hline Name & Sigla & Formula estrutural \\
\hline 2,3,4,5-tetrahidro- piridina & $\mathrm{P}-1 \mathrm{~N}$ & \\
\hline $\mathrm{N}$-(fenilmetil)-benzenometanamina & $\mathrm{P}-2 \mathrm{~N}$ & \\
\hline Etinil-, carbamato ciclohexanol & $\mathrm{P}-3 \mathrm{~N}$ & \\
\hline 1-nitroetil- benzeno & $\mathrm{P}-4 \mathrm{~N}$ & \\
\hline $\begin{array}{l}\text { 5-Metil-6,7-dihidro-(5H)- } \\
\text { ciclopentapirazina }\end{array}$ & $P-5 N$ & \\
\hline 1-pentil-1H-pirrol & $P-6 N$ & \\
\hline
\end{tabular}




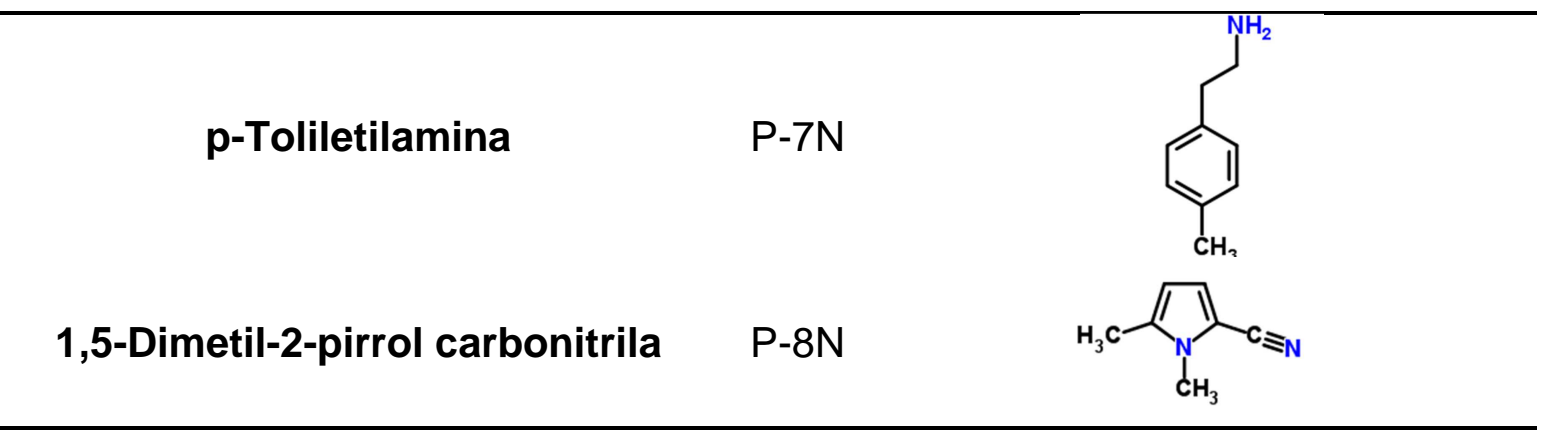

Para a melhor compreensão da interação da radiação ionizante com os compostos nitrogenados contrui-se o gráfico apresentado na Figura $25 \mathrm{com}$ a área de cada pico, dos compostos identificados na Tabela 20 , em função da dose absorvida de radiação. A partir desta é possível inferir que a maioria dos compostos se degradaram com as doses de 15 kGy e de 50 kGy.

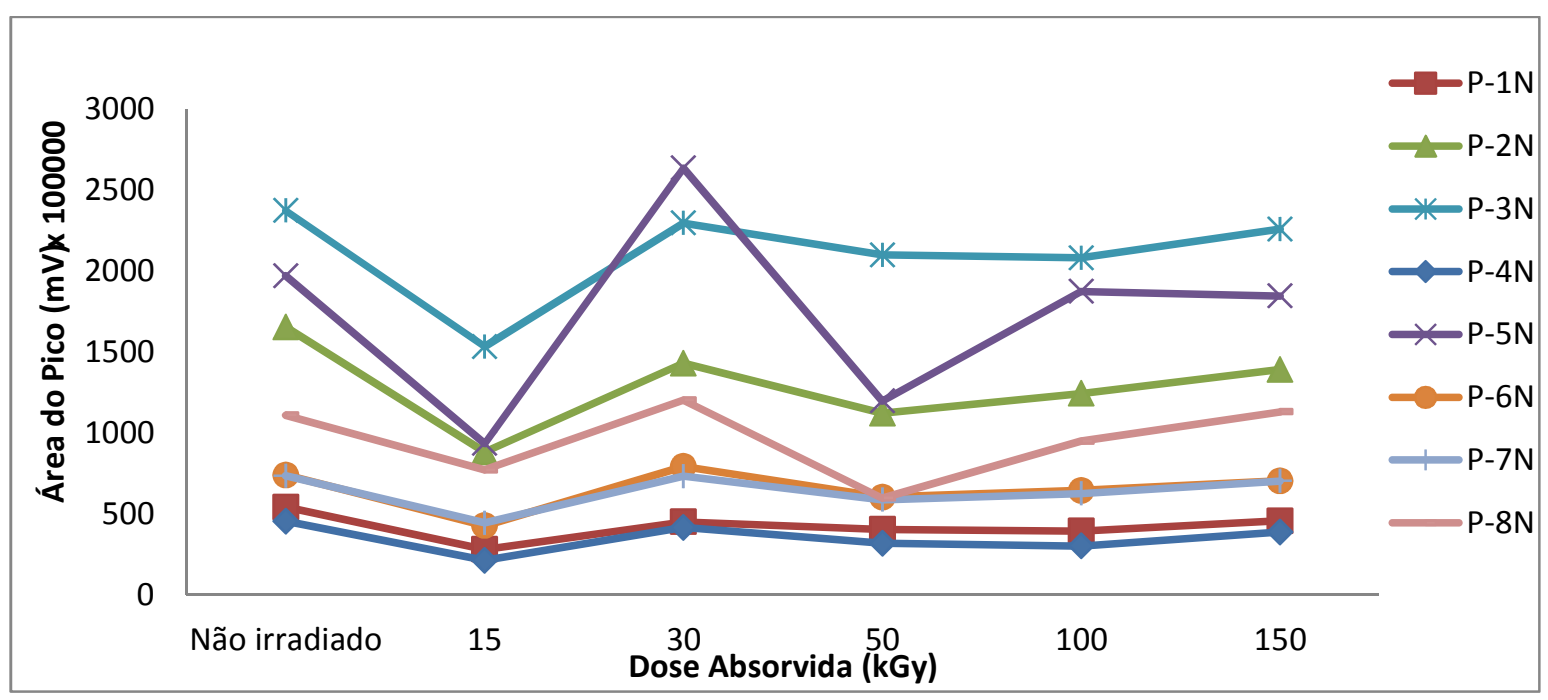

Figura 25. Relação entre a área e a dose dos compostos de nitrogênio no petróleo.

A variação das concentrações foram calculadas em forma de porcentagem em relação a amostra não irradiada, os resultados são expostos na Tabela 21. Para os compostos nitrogenados em questão observou-se que a dose de 15 kGy foi mais efetiva na degradação dos mesmos, com exceção do P-8N que teve $46 \%$ de degradação com 50 kGy. 
Tabela 21. Remoção de compostos nitrogenados (\%) da amostra de petróleo após a irradiação

\begin{tabular}{c|ccccc}
\hline Sigla & \multicolumn{5}{c}{ Dose Absorvida (kGy) } \\
& $\mathbf{1 5}$ & $\mathbf{3 0}$ & $\mathbf{5 0}$ & $\mathbf{1 0 0}$ & $\mathbf{1 5 0}$ \\
\hline P-1N & 48 & 17 & 25 & 27 & 16 \\
P-2N & 47 & 14 & 32 & 25 & 16 \\
P-3N & 35 & 3 & 12 & 12 & 5 \\
P-4N & 53 & 9 & 30 & 34 & 15 \\
P-5N & 53 & ${ }^{*}-34$ & 39 & 5 & 6 \\
P-6N & 42 & -7 & 18 & 13 & 5 \\
P-7N & 40 & 0 & 20 & 15 & 4 \\
P-8N & 31 & ${ }^{*}-8$ & 46 & 14 & ${ }^{*}-2$ \\
\hline
\end{tabular}

*Os valores negativos observados na Tabela são referentes ao aumento da concentração dos compostos quando submetidos à irradiação.

Cabe ressaltar que a estrutura molecular dos compostos interfere na forma com a qual a radiação interage com os mesmos, os $\mathrm{N}$-(fenilmetil)Benzenometanamina, etinil-, carbamato ciclohexanol,1-nitroetil-benzeno e pToliletilamina, possuem nitrogênio fora do anel aromático fator que facilita a transformação destes em compostos de menor complexidade, o compostos etinil-, carbamato ciclohexanol tem uma redução menor com a dose de $15 \mathrm{kGy}$ devido a presença de oxigênio, que esta ligado ao carbono, de modo que os radicais livres interagem preferencialmente com estes.

Para os compostos, nos quais o nitrogênio esta diretamente ligado ao anel aromático, como no, 1-pentil-1H-pirrol, 5-Metil-6,7-dihidro-(5H)ciclopentapirazina e 1,5,-Dimetil-2-pirrol carbonitrila, deve se levar em consideração a existência de cadeias laterais, que se decompõem, neste caso os compostos nitrogenados foram convertidos em compostos mais leves.

\subsubsection{Espectroscopia do Infravermelho}

Realizou-se também espectroscopia ATR-FTIR, no petróleo sem tratamento prévio (ANEXO D), nestes não houve mudanças perceptíveis com diferentes doses de irradiação. Entretanto após a destilação observou-se uma 
diferença sutil entre os espectros, principalmente na região entre $650-1200 \mathrm{~cm}^{-1}$, conhecida como fingerprint, esta região é característica de substituinte alquila, como pode se observar na Figura 26.

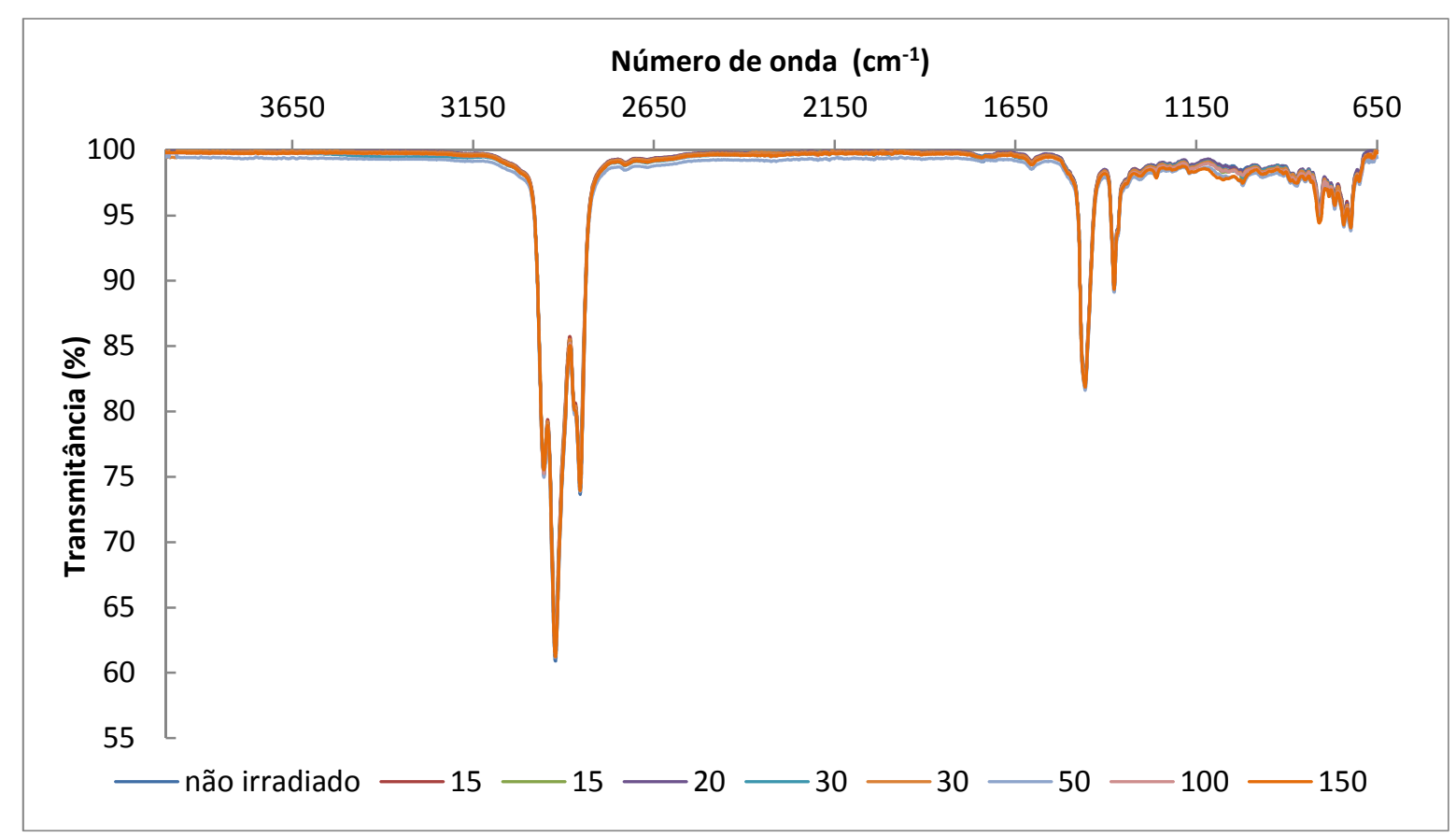

Figura 26. Espectros de infravermelho do petróleo irradiado e destiladas. 


\section{CONCLUSÃO}

Para o desenvolvimento do presente trabalho foram necessários vários estudos, como a molécula modelo, BT, as separações químicas dos compostos orgânicos no diesel e no petróleo e a avaliação dos efeitos da radiação ionizante nas diferentes amostras.

Quanto ao estudo preliminar dos compostos sulfurados, utilizando a molécula modelo, a radiação ionizante levou a degradação maior que $95 \%$ do benzotiofeno $\mathrm{e}$ os principais compostos formados foram o tolueno, o dimetilbenzeno, o benzotiofano e o tiofeno. Pelo estudo realizado com metanol foi possível comprovar que a decomposição do BT se dá, principalmente pela ação do radical hidroxila.

No estudo do diesel, a concentração total de enxofre não variou após o processo de radiação, logo é possível inferir que os compostos sulfurados transformam se em outros compostos, mas não em H2S que seria eliminado por evaporação após a formação. O método de separação cromatográfica dos compostos alifáticos e aromáticos proposto foi eficiente e reprodutível, no entanto compostos alifáticos de alto peso molecular eluiram juntamente com a fração analisada.

A degradação dos hidrocarbonetos após o processamento por irradiação do diesel foi maior para doses absorvidas menores (15 kGy e 30 kGy), sendo que, para doses elevadas, houve a interação dos hidrocarbonetos com radicais livres, levando à polimerização, reduzindo a eficiência. No caso dos compostos nitrogenados presentes no diesel as doses mais eficientes foram as de 30 kGy e 50 kGy, entretanto nenhum dos compostos estudados degradou acima de $50 \%$. Os compostos sulfurados alfametil alfafenil bezenometanotiol apresentou maior decomposição que o 1 etil sulfonil buteno e o benzotiofeno

A técnica de fluorescência de raios-x foi fundamental para o estudo de compostos sulfurados no petróleo, principalmente após a destilação das amostras irradiadas. Constatou-se que as amostras irradiadas com as doses de 15 e 30 
kGy tiveram uma redução acima de $50 \%$ no teor de enxofre, tornando possível inferir que houve a dessulfurização parcial das frações mais leves.

Para a amostra de petróleo, a separação cromatográfica dos compostos orgânicos sulfurados com cloreto de paládio foi mais eficiente que com o carvão ativo, entretanto com este foi possível avaliar o comportamento dos isômeros.

Pelo controle da temperatura de destilação foi possível comprovar que, após a irradiação com dose de $15 \mathrm{kGy}$, os hidrocarbonetos foram decompostos em frações mais leves e doses maiores levaram à reações entre radicais com aumento do peso molecular. Outro fator relevante foi o craqueamento em doses menores, considerada positiva, uma vez que diminuiria a energia necessária no processo de destilação.

Finalmente os resultados obtidos demonstraram que a utilização da radiação ionizante para degradação dos compostos, principalmente os sulfurados no petróleo e no diesel pode ser promissora tecnicamente e pode ser associada com o HDS ou algum outro processo bem desenvolvido, agregando benefícios. 


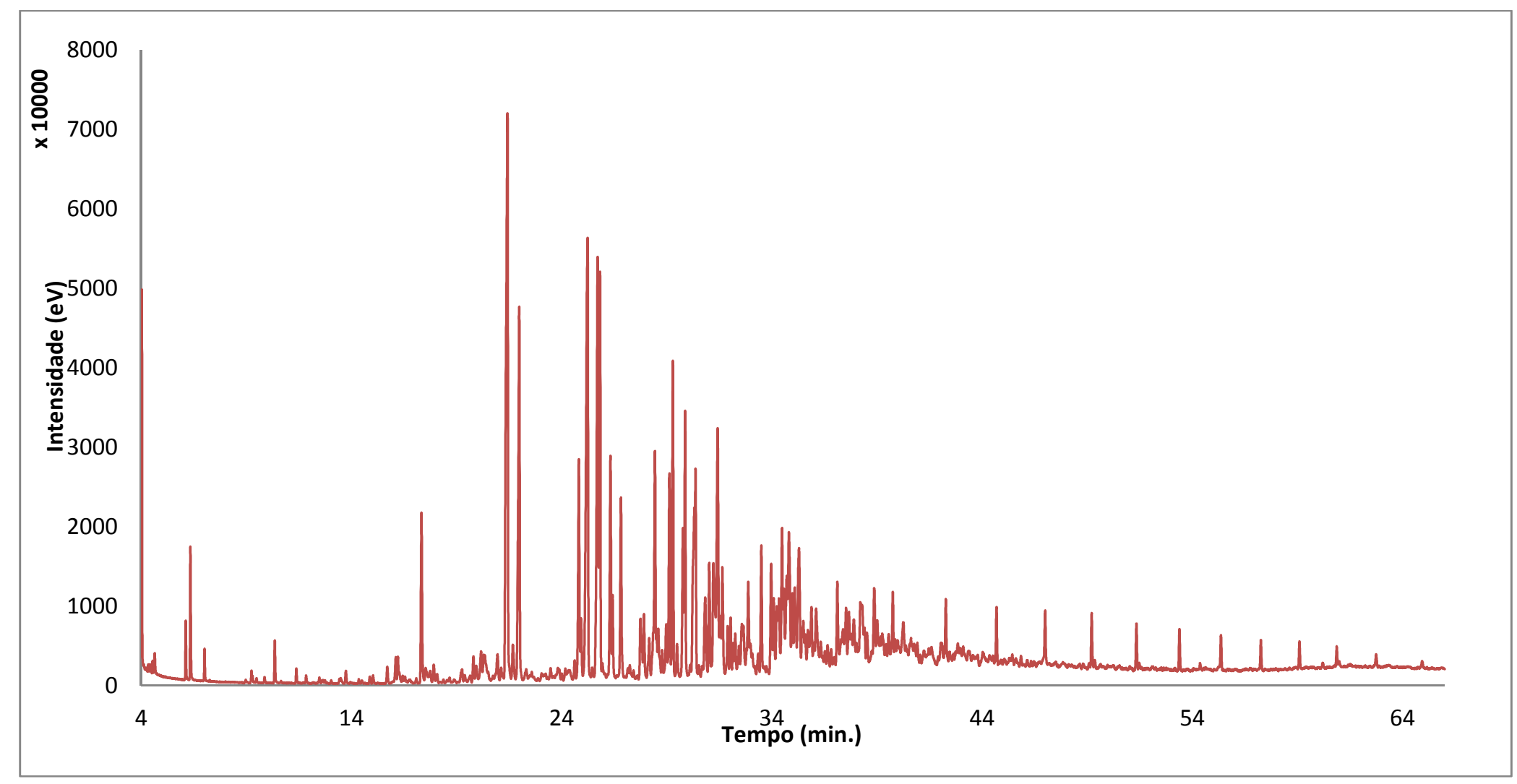






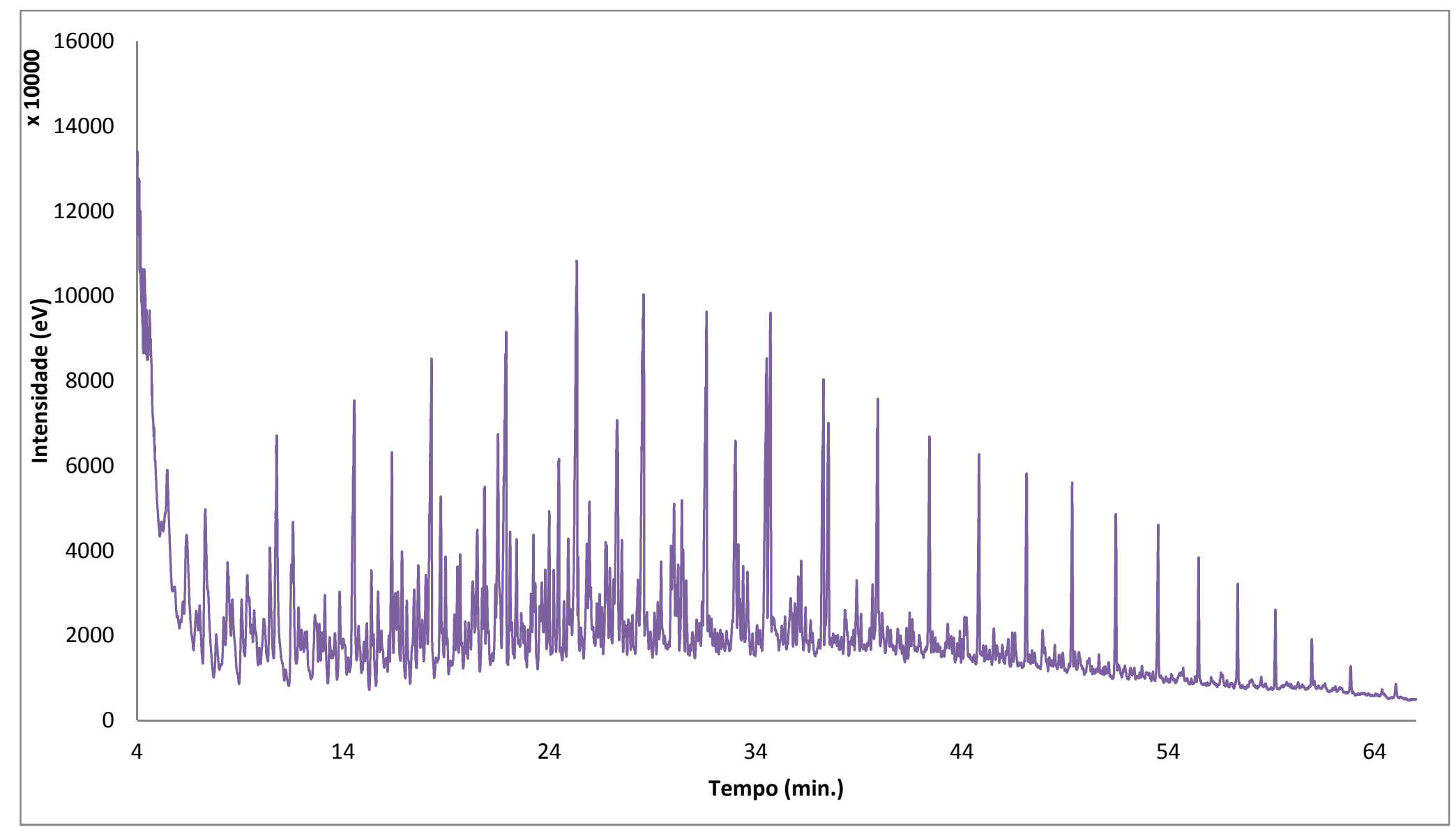

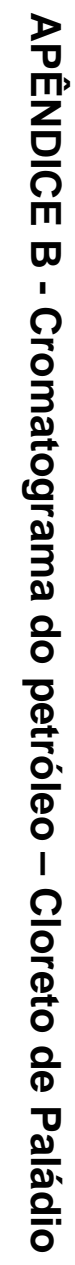




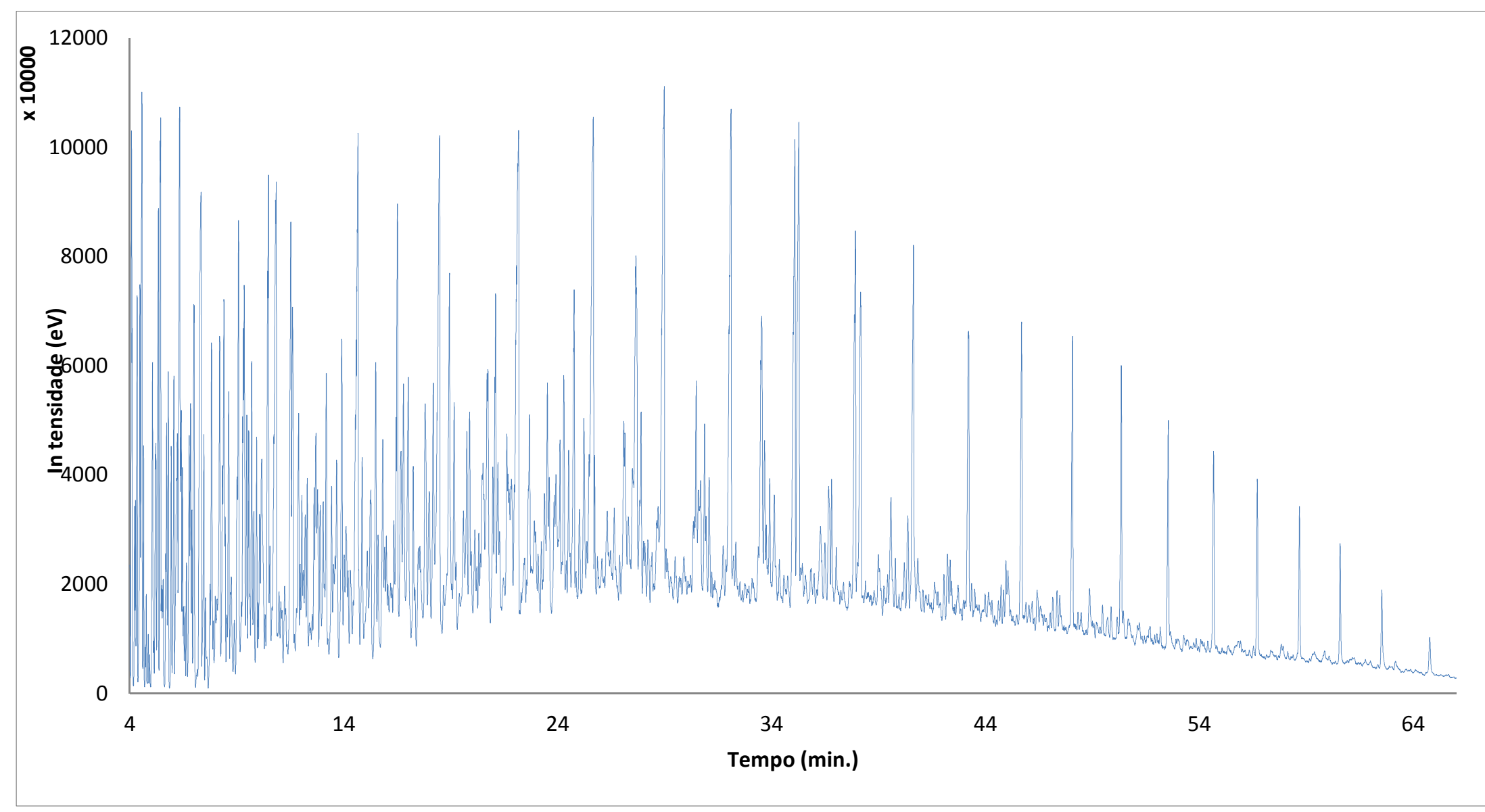

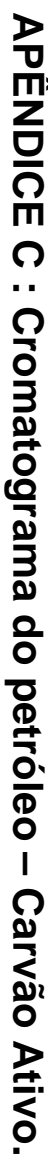




\section{REFERÊNCIA BIBLIOGRAFICA}

1. ABDEL-AAL,H.K.; FAHIM, M. A.; AGGOUR, M. CRC. 2003. Petroleum and Gas Field Processing. cap.2. Composition and Characteristics of Crude Petroleum.

2. ANP- Agencia Nacional do Petroleo, Gás Natural e Biocombustível. Resolução ANP no 38, de 9 de dezembro de 2009.

3. ANP- Agencia Nacional do Petroleo, Gás Natural e Biocombustível. Resolução ANP no 42, 16 de dezembro de 2009.

4. BASFAR, A. A.; MOHAMED, K. A. Radiation-Induced Desulfurization of Arabian Crude Oil and Straight-Run Diesel. Radiation Physics and Chemistry, v.80, p.1289-1290, 2011.

5. CHENG, X.; ZHAO,T.; FU, X.; HU, Z. Identification of Nitrogen Compounds in RFCC Diesel Oil by Mass Spectrometry. Fuel Processing Technology, v.85, p. 1463-1472, 2004.

6. DEPAUW, G. A.; FROMENT, G. F. Molecular Analysis of the Sulphur Components in a Light Cycle Oil of a Catalytic Cracking Unit by Gas Chromatography with Mass Spectrometric and Atomic Emission Detection. Journal of Chromatography A, v. 761, p. 231-247, 1997.

7. DUARTE, C. L.; GERALDO, L. L.; P. JUNIOR, O .A.; BORRELY, S . I.; SATO, I. M.; SAMPA, M. H. O. Treatment of Effluents from Petroleum Production by Electron Beam Irradiation. Radiation Physics and Chemistry, v. 71, p. 445459, 2004.

8. DUARTE, C. L.; SAMPA,M. H. O.; RELA, P. R.; OIKAWA H.; SILVEIRA, C. G. Advanced Oxidation Process by Electron-Beam-Irradiation Induced Decomposition of Pollutants in Industrial Effluents. Radiation Physics and Chemistry, v.63, p. 647-51, 2002.

9. DUARTE, C L. Aplicação Do Processo Avançado de Oxidação Por Feixe de Elétrons $\mathrm{Na}$ Degradação de Compostos Orgânicos Presentes Em 
Efluentes Industriais. 1999. Tese (doutorado) - Instituto De Pesquisas Energéticas E Nucleares, São Paulo.

10. FAHIN, M. A.; AL-SAHHAF, T. A. Introdução ao Refino de Petróleo - Série Engenharia de Petróleo. Elsevier, 2012.

11. FAN, T.; BUCKLEY, J S. Rapid and accurate sara analysis of medium gravity crude oils. Energy \& Fuels, v.47, p. 1571-75, 2002.

12. FÖLDIÁK, G. Radiolysis of Liquid Hydrocarbons. Radiation Physics and Chemistry, v.16, p. 451-63, 1980.

13. HOF. M. Basics of Optical Spectroscopy. in: Gauglitz, G.;Vo-Dinh, T. Handbook of Spectroscopy, WILEY-VCH Verlag GmbH \& Co. KGaA, Weinheim. p. 38- 168, 2003.

14. HERBERT, C. G.; JOHNStONE, R. A. W. Capitulo 36. Gas Chromatography/Mass Spectrometry (GC-MS). in: HERBERT, C.G.; JOHNSTONE, R. A. W. Mass Spectrometry Basics, CRC, 2003.

15. HERNÁNDEZ-MALDONADO, A J.; YANG, F.H.; QI, G.; YANG, R. T. Desulfurization of Transportation Fuels by P-complexationsorbents: $\mathrm{Cu}(\mathrm{I})$-, $\mathrm{Ni}(\mathrm{II})-$, and $\mathrm{Zn}(\mathrm{II})$-Zeolites. Applied Catalysis B: Environmental, v. 56, p. 111- 126, 2005.

16. HILSDORF, J. W.; BARROS,N. D.; TASSINARI, C. A.; COSTA, I. Química Tecnológica. São Paulo: PioneiraThomsom Learning. 2004.

17. JARULLAH, A. T.; MUJTABA, I.M.; WOOD, A. S. Kinetic Parameter Estimation and Simulation of Trickle-Bed Reactor for Hydrodesulfurization of Crude Oil. Chemical Engineering Science, v. 66, n.5, p.859-871, 2011.

18. JORGE, E. Conama 315/2002. Folha de São Paulo, São paulo, 08 set. 2007. Cotidiano, Opinião.

19. JR, C E. B.. Industrial Combustion Pollution and Control. New York: MARCEL DEKKER, INC, 2004. cap 8, Sulfur Oxides $\left(\mathrm{SO}_{\mathrm{x}}\right)$. p. 379-402 .

20. JÚNIOR,G. Processamento Primário de Petróleo / Noções de Processo de Refino.Disponivel em: <http://www.tecnicodepetroleo.ufpr.br/apoio_didatico.htm>. Acessado em: 10 abr. 2011. 
21. KENKEL, J. 2003. Analytical Chemistry for Technician. CRC, 2003. cap. 2, Sampling and Sample Preparation, p. 17-35 .

22. KOWALEWSKA, Z. Feasibility of High-Resolution Continuum Source Molecular Absorption Spectrometry in Flame and Furnace for Sulphur Determination in Petroleum Products. Spectrochimica Acta Part B: Atomic Spectroscopy, v. 66, n. 7, p. 546-556, 2011.

23. LANÇAS, F. M. Cromatografia liquida moderna - HPLC/CLAE. Átomo, 2009. cap. 12. Preparo da amostra. p. 251-315.

24. LATER, D. W.; LEE, M. L.;. BARTLE, K. D.; KONG, R. C.; VASSILAROS, D. L. Chemical Class Separation and Characterization of Organic Compounds in Synthetic Fuels. Analytical . Chemistry, v. 53, n. 11, p. 1612-1620, 1981.

25. LAVERNE, J.A.; SCHULER, R. H. Track Effects in Radiation Chemistry: Core Processes in Heavy-Particle Tracks as Manifest by the $\mathrm{H} 2$ Yield in Benzene Radiolysis. The Journal Physical. Chemitry, v. 88, p. 1200-1205, 1984

26. LEMBERCK, S.. "O Pré - Sal: Uma Visão Econômica, Social, Ambiental e Politica." in: Petróleo, Energia e Meio Ambiente, 2010, Rio de Janeiro.disponivel em: <http://www.sergiolemberck.com.br>. Acessado em: 19. jul. 2012.

27. LI, M., FOWLER, M. G.; OBERMAJER, M.;. STASIUK, L. D ; SNOWDON, L. R. "Geochemical characterisation of Middle Devonian oils in NW Alberta, Canada : possible source and maturity effect on pyrrolic nitrogen compounds. Organic Geochemistry, v. 30, p. 1039-1057, 1999.

28. LISSNER, E. A.. Extração Oxidativa de Organossulfurados E Extração de Nitrogenados Por Liquidos Ionicos Funcionalizados. 2012. Tese (Doutorado)- Universidade Federal do Rio Grande do Sul, Porto Alegre.

29. MACHADO, M. E.. Determinação de Compostos Orgânicos Sulfurados Em Carvão E Petróleo Por Cromatografia Gasosa Monodimensional E Bidimensional Abrangente. 2011. Tese (Doutorado) - Universidade Federal do Rio Grande do Sul, Porto Alegre.

30. MAChADO, M. E.; MENEZES,E. W.; BREGleS, L. P. CARAMÃO, E. B. ; BENVENUTTI,E. V.; ZINI, C. A. Palladium(II) Chemically Bonded to Silica Surface Applied to the Separation and Identification of Polycyclic Aromatic 
Sulfur Heterocycles in Heavy Oil. Journal of Separation Science, v. 36, p. 1636-1643, 2013.

31. MACHADO, M. E.; FONTANIVE, F. C.; OLIVEIRA, J. V.; CARAMÃO, E. B.; ZINI. C. A.. Identification of organic sulfur compounds in coal bitumen obtained by different extraction techniques using comprehensive two-dimensional gas chromatography coupled to time-of-flight mass spectrometric detection. Analytical and bioanalytical chemistry, v. 401, p. 2433-2444, 2011.

32. MARIANO, J. B. Impactos Ambientais Do Refino de Petróleo. 2001. Dissertação (Mestrado) - Universidade Federal do Rio de Janeiro, Rio de Janeiro.

33. MCCAIN JR, W. D. Componentes of naturally occuring in petroleum fluids. In: MCCAIN JR, W. D. The Properties of Petroleum Fluids. Pennwell Publishing Company, 1990, p 1-42.

34. MEDEIROS, MARINA ÁUREA DE O., ANTONIO SOUZA ARAÚJO, AND NEDJA SUELY FERNANDES. Estudo comparativo das propriedades físicoquímicas do óleo diesel combustível nos estados do RN E PB. In: $2^{\circ}$ CONGRESSO BRASILEIRO DE P\&D EM PETRÓLEO \& GÁS. 2003, Rio de Janeiro. Disponivel em :<http://www.portalabpg.org.br/PDPetro/2/7016.pdf>. Acessado em: 11 out. 2013.

35. MIKI, Y.; TOBA, M.; YOSHIMURA, Y. Separation of Sulfur Compounds in Straight-Run Naphtha. The chemical society of Japan, v. 80, n. 11, p. 21572160, 2007

36. MIKI, Y.; TOBA, M.; YOSHIMURA, Y. Analysis of Sulfur Compounds in Straight-Run Naphtha and FCC Gasoline. Journal of the japan petroleum institure,v. 51, n. 4, p. 225-33, 2008.

37. MÜLEN, C. V. Caracterização química de compostos nitrogenados do petróleo brasileiro e de óleos voláteis de plantas brasileiras usando cromatografia gasosa bidimensional abrangente. 2007. Tese (Doutorado) - Universidade Federal do Rio Grande do Sul, Porto Alegre.

38. MURTI S D. S.; SAKANISHI, K.; OKUMA, O.; KORAI,Y.; MOCHIDA. I.Detailed Characterization of Heteroatom-Containing Molecules in Light 
Distillates Derived from Tanito Harum Coal and Its Hydrotreated Oil. Fuel, v. 81, n. 17, p. 2241-2248, 2002.

39. NAGAISHI, R.; KUMAGAI. Y. Radiolysis of Water. In: YAN, X. L.; HINO,R. Nuclear Hydrogen Production Handbook. New York: Taylor \& Francis Group, 2011. p. 177-187

40. NATIONAL ENERGY TECHNOLOGY LABORATORY. A Literature Review on Cold Cracking of Petroleum Crude Oil. Energy Policy Act of 2005 Section: 1406. Jul. 2006. Disponivel em: < http://fossil.energy.gov/epact/cold_cracking_report.pdf> Acessado em: 29 mai. 2012.

41. NISHIOKA, M.. Aromatic sulfur compounds other than condensed thiophenes in fossil fuels: enrichment and identification. Energy \& Fuels. v.2, p. 214$219,1988$.

42. OLIVEIRA, E. C. Estudo dos compostos nitrogenados em frações do petróleo. 2004. Tese (Doutorado) - Universidade Federal do Rio Grande do Sul, Porto Alegre.

43. PANDA, S. K.; ANDERSSON, J. T.; SCHRADER, W. Mass-Spectrometric Analysis of Complex Volatile and Nonvolatile Crude Oil Components: A Challenge. Analytical and bioanalytical chemistry. v. 389, n.5, p. 1329 1339, 2007.

44. PASADAKIS, N.; KARONIS, D.; MINTZA, A. Detailed compositional study of the light cycle oil (LCO) solvent extraction products. Fuel Processing Technology, v. 92, n. 8, p. 1568-1573, 2011.

45. PETROBRAS. Processo de Refino. Adaptado do material original de ABADIE, E. 2002. Disponivel em:< http://www.tecnicodepetroleo.ufpr.br/apoio_didatico.htm > Acessado em : 30 abr. 2011.

46. POTTS, P J. X-Ray Fluorescence Analysis. In: SMITH, K. A.; CRESSER, S. M. Soil and Environmental Analysis Modern Instrumental Techniques. New York: MARCEL DEKKER, INC, 2003. 
47. QIAN, K.;DECHERT, G. J. Recent advances in petroleum characterization by GC Field Ionization Time-Of-Flight High-Resolution Mass Spectrometry. Analytical chemistry, v 74, n.16, p. 3977-3983, 2002.

48. RASHED, I. G.; HANNA, M. A. ; El-GAMAM, H. F.; AL-SARAWY, A. A.; WALI, F. K. M. Overview on chemical oxidation technology in wastewater treatment. In: Ninth International Water Technology Conference, p.115132, 2005.

49. SALEM, A. B. S. H. Naphtha Desulfurization by Adsorption. Industrial and Engineering Chemistry Research, v. 33, n. 2, p. 336-340, 1994

50. SANTOS, F. K. G. Remoção de Enxofre Na Mistura CiclohexanoPropanotiol Através de Processos de Adsorção Sobre AIPO E MeAPOs. 2005. Dissertação (Mestrado) - Universidade Federal de Campina Grande.

51. SILVA, T. E. P.; CARVALHO, D. O.; SILVA, M. J. P.; SANTOS, N. E. S. COSTA, P. P. R. Enxofre: Um poluente em potencial na composição do óleo diesel brasileiro. In. IV CONGRESSO BRASILEIRO DE GESTÃO AMBIENTAL. Salvado- BA, 2013

52. SPEIGHT, J. G. The Desulfurization of Heavy Oils and Residua. New York: MARCEL DEKKER, INC. 1999.

53. SPEIGHT, J. G. Handbook of Petroleum Analysis. New York: Wiley Interscience. 2001

54. SPEIGHT, J. G. Handbook of Petroleum Product Analysis. New York: Wiley Interscience. 2002

55. SPEIGHT, J. G. The Chemistry and Technology of Petroleum. New York: Taylor \& Francis Group, 2006.

56. THOMAS, J. E. Fundamentos-de-Engenharia-de-Petroleo. Rio de Janeiro: Interciência, 2001.

57. VIALLI, A.. 2008. "Impasse sobre a redução do teor de enxofre no diesel esta longe do fim, dizem ongs. Jormal Estado de S. Paulo, 08 aug. 2008. disponivel em:< (http://www.estadao.com.br/noticias/impresso, impasse-sobrereducao-de-enxofre-no-diesel-esta-longe-do-fim-dizem-ongs,224290,0.htm)> Acessado em: fev. 2013. 
58. WANG, Z.; FINGAS, M. F. Development of Oil Hydrocarbon Fingerprinting and Identification Techniques. Marine pollution bulletin, v. 47, p. 423-452, 2003.

59. WOJNÁROVITS, L. Radiation Chemistry. In: VERTES, A. NAGY, S.; KLEMCSAR, Z. Handbook of Nuclear Chemistry - Applications of Nuclear Reations and Radiations. Netherlands, 2003. p. 1-55.

60. WOJNAROVITS, L.; SCHULER, R. H. Bond Rupture in the Radiolysis of N Alkanes: An Application of Gel Permeation Chromatography to Studies of Radical Scavenging by lodine. J. Physical Chemistry, v. 104, n. 6, p. 13461358, 2000.

61. WOODS, R. J.Radiation Chemistry and Its Application to Environment Pollution. In: COOPER, W. J.; CURRY, R. D.; O'SHEA, K. E. Environmental Applications of lonizing Radiation. New York, John Wiley \& Sons, Inc., p. 132, 1988

62. WU, J. C.; SUNG, H.; LIN,Y.; LIN, S. Removal of Tar Base from Coal Tar Aromatics Employing Solid Acid Adsorbents. Separation and Purification Technology, v. 21, p. 145-153, 2000.

63. XIAOLAN, Z. ; JUN, L.; JIANHUA, L.; YONGTAN, Y. Speciation Distribution of Polycyclic Aromatic Sulfur Heterocycles in Crude Oil. Chinese Journal of analytical chemistry, v. 34, n. 11, p. 1546-1550, 2006.

64. YANG, K.;MANNO, P.J. The Role of Free Radical Processes in the ГRadiolysis of Methane, Ethane and Propane. Journal of the American Chemical Society, v 81, n 14, p. 3507-3510, 1959.

65. ZAYKIN, Y. A. Radiation-Induced Cracking of Hydrocarbons. In: KHARISOV, B. I.; KHARISSOVA, O. V.; MENDEZ, U. O. Radiation Synthesis of Materials and Compounds. New York: Taylor \& Francis Group, 2013.p. 357380

66. ZAYKIN, Y. A. Low-Temperature Radiation-Induced Cracking of Liquid Hydrocarbons. Radiation Physics and Chemistry, v. 77, n. 9, p.1069-1073, 2008

67. ZAYKIN, Y. A.; ZAYKINA. R .F. "New Trends in the Radiation Processing of Petroleum." in: CAMILLERI, A .N. Radiation Physics Research Progress. new York: Nova, 2007. p. 14-104 
68. ZAYKIN, Y. A.; ZAYKINA, R. F. Bitumen Radiation Processing. Radiation Physics and Chemistry, v. 71, p. 471-74, 2004.

69. ZAYKIN, Y. A.; ZAYKINA, R. F.; SILVERMAN, J. Radiation-Thermal Conversion of Paraffinic Oil. Radiation Physics and Chemistry, v. 69, n. 3 , p. 229-238, 2004.

70. ZAYKINA, R. F.; ZAYKIN, Y. A.; YAGUDIN, S. G.; FAHRUDDINOV, I. M. Specific Approaches to Radiation Processing of High-Sulfuric Oil. Radiation Physics and Chemistry, v. 71, p. 467-470, 2004.

71. ZAYKINA, R. F.; ZAYKIN, Y. A.; MAMONOVA, T. B.; NADIROV, N. K. Radiation Methods for Demercaptanization and Desulfurization of Oil Products. Radiation Physics and Chemistry, v. 63, p. 621-624, 2002.

72. ZHANG, G.; YU, F.; WANG, R. Research Advances in Oxidative Desulfurization Technologies for the Production of Low Sulfur Fuel Oils. Petroleum \& Coal, v. 51, n. 3, p.196-207, 2009. 